\title{
Giovanni Ciotti and Marco Franceschini Certain Times in Uncertain Places: A Study on Scribal Colophons of Manuscripts Written in Tamil and Tamilian Grantha Scripts
}

\section{Introduction}

In this article, we present the initial results of our ongoing collaborative research, which aims to produce a comprehensive study of colophons found in manuscripts written in Tamilian Grantha and/or Tamil scripts. ${ }^{1}$ In keeping with the theme of the present volume, we have focused our investigation on the temporal and spatial data that are found in such colophons.

The premises of our project are rooted in Marco Franceschini's preparatory work for his forthcoming monograph on the evolution of Tamilian Grantha script as found in manuscripts from Tamil Nadu and neighbouring areas. It is evident that the results of this palaeographical research should be combined with other manuscript-related investigations, such as those conducted on colophons, in order to reach a thorough understanding of the features of the manuscript culture of that region - or, indeed, of any other regions.

Before continuing, it is necessary to specify what we mean here by the term 'colophon'. In our understanding, this is a short paratext containing information about the production, internal organisation and storage of a particular manuscript. In this respect, one could name a colophon of this type a 'scribal colophon', since it is composed by scribes and generally relates to the material aspects of a specific

The research for this article was carried out within the scope of the work conducted by (1) the SFB 950 'Manuskriptkulturen in Asien, Afrika und Europa' / Centre for the Study of Manuscript Cultures (CSMC), Hamburg, funded by the German Research Foundation (Deutsche Forschungsgemeinschaft, DFG) and (2) NETamil 'Going From Hand to Hand: Networks of Intellectual Exchange in the Tamil Learned Traditions', Hamburg / Pondicherry, founded by the European Research Council $(E R C)$. Although this article is the result of a collaboration, and would not otherwise have existed in its present form, the authorship of sections 1, 2, 3, 5 and Appendix 2 should be attributed to Giovanni Ciotti and that of section 4 and Appendix 1 to Marco Franceschini.

1 Tamilian Grantha is sometimes referred to as Grantha Tamil in the secondary literature. 
manuscript. ${ }^{2}$ Being a text in itself, a colophon is composed according to a set of more or less fixed conventions, which translate, for instance, into a formulaic use of the language (e.g. use of a specific lexicon, fixed invocations, etc.) and a number of graphic devices (e.g. puspikās and pillaiyār culis ${ }^{3}$ ). Colophons are among the main means by which scholars can outline the aspects characterising a manuscript culture - in the present case that of Tamil Nadu. In fact, they are the sources of a wide variety of data that are not only of a temporal and spatial nature, but which also pertain to the identities of the scribes and owners of manuscripts; the religious environment in which manuscripts were produced, the features of the language or languages - used by the scribes (Wagner et al. 2013) and the categories into which literature was organised (e.g. colophons may contain labels used to name literary genres), etc. ${ }^{4}$ As for the manuscript material under consideration here, colophons are quite rare. In the absence of an exhaustive statistical study, it is possible to estimate that only one manuscript in five to ten contains colophonic material (see also Wilden 2014: 363 for a similarly impressionistic account).

\section{The corpus}

The corpus that we decided to examine here is limited in extent, numbering a total of 45 colophons found in 28 manuscripts (see Appendix 2 for their transcriptions and translations). The discrepancy between the number of colophons and

2 In the manuscript culture under investigation here, it is difficult to ascertain whether scribes used to reproduce colophons along with the texts of the manuscripts they were copying. In fact, we generally do not possess antigraphs. As far as dates are concerned, it seems that colophons were not copied very often.

3 Pușpikās ('small flowers') are floreal signs that are variously used in South Asian manuscripts, in order to mark sections of a text, such as its beginning, end and its subdivisions. On the other hand, pillaiyār culis ('Ganeśa's trunk') are peculiar to the manuscript culture of southern India, and are used both as section markers and as auspicious signs.

4 Ever since we began our research, it has been clear to us that manuscripts written in other scripts such as Telugu and Grantha Malayalam should also be taken into account if we are to examine the manuscript culture of Tamil Nadu properly, if only for the reason that quite a number of manuscripts written in Tamilian Grantha and/or Tamil scripts also contain short colophons written in the Telugu language and in Telugu script, e.g. RE45807 (see fn. 55). This means that in future we will welcome the collaboration of colleagues whose expertise can help us to enlarge the scope of our investigation towards a broader understanding of the manuscript culture of Tamil Nadu and, indeed, of South India in general. 
manuscripts stems from the fact that some of the latter are multiple-text manuscripts, whereas others contain colophons that mark both the dates when the scribal activity began and when it ended. By building an ad hoc repertoire we intend to offer a first systematisation of the wide typological variety we have so far encountered. As a consequence, at present, we do not claim any statistical value for the results of our study, although this is, of course, a further aim that we will pursue in our ongoing investigation once we are able to deal properly with larger amounts of data. It goes without saying that adding more and more cases to our repertoire will challenge our first systematisation, possibly by revealing new typologies of colophons. Thus, allowance must be made for a certain degree of flexibility in our ongoing research.

Furthermore, one should note that the size of our corpus has been affected by the nature of the extant catalogues of manuscript collections preserved in various libraries in Tamil Nadu. Unfortunately, they rarely record colophons in their entirety. The catalogues of the two main manuscript collections in Pondicherry are exceptions to this rule: the catalogue of the Institut français de Pondichery (IFP) in four volumes (Varadachari 1986, 1987, 1990; Grimal and Ganesan 2002), a remarkable piece of scholarship, indeed, which, however, does not encompass the whole collection; and the catalogue of the École française d'Extrême-Orient (EFEO) in Pondicherry, which at present mainly consists of the unprinted sheets prepared by Pandit R. Varadadesikan and, again, does not feature the whole collection. We selected the majority of the colophons in our corpus from these two collections. Furthermore, we took the manuscripts written in Tamilian Grantha into consideration that belong to the collection held at the University Library of Cambridge (Marco Franceschini has recently compiled the first catalogue of these items for the Cambridge Sanskrit Manuscripts Project). As for manuscripts written in Tamil script, we were able to access images of palm-leaf manuscripts collected by the Cańkam Project (EFEO, Pondicherry), including, in particular, the poems of the Cankam and Kìlkkanakku corpora. Finally, we also included one manuscript written in Tamilian Grantha held at the Leiden University Library (formerly the Van Manen Collectie).

In the following article, manuscripts are referred to by their accession numbers. Each of them bears a siglum that indicates the library in which they are held: RE for IFP, EO for EFEO, OR for Cambridge University Library, UVSL for U.V. Swāmināthaiyar Library (Makāmakōpātyāya Ṭākțar U. Vē. Cāminātaiyar Nūlnilai) in Chennai, and MS for Leiden University Library.

Despite the usefulness of catalogues, for our study it has been necessary to check each manuscript in order to confirm (and not seldom amend) the recorded 
data and to account for all the elements that we intend to study, given our definition of a colophon. Catalogues, for instance, do not always regard invocations as part of colophons. This examination was possible thanks to the fact that most of the manuscripts studied here are available in digital form. In particular, the fact that both the IFP and the EFEO collections have been digitised in line with very high standards has given us the possibility of engaging extensively with such valuable material. Bearing this in mind, the present article intends to show - to the best of the abilities of its authors - how important digitising collections is in furthering our understanding of manuscript cultures.

\section{Linguistic considerations}

From the linguistic point of view, the manuscripts we deal with contain text written in Sanskrit, Tamil and Manipravalam. The latter is a mix of the previous two, mostly blending the Sanskrit lexicon with Tamil morpho-syntax. ${ }^{5}$ In this respect, Manipravalam could be considered as a highly Sanskritised register of Tamil, where the frequency of Sanskrit lexemes depends on the style of each author (see Venkatachari 1978).

In order to write these languages, two scripts are generally used, namely Tamil script for the Tamil language and Tamilian Grantha for Sanskrit. When it comes to Manipravalam, the latter is mostly employed, but cases in which a combination of both scripts are used are relatively frequent. A deeper investigation of this phenomenon is still a desideratum. ${ }^{6}$

A question that immediately arises is whether any differences in terms of language choice occur between colophons found in manuscripts containing Sanskrit, Tamil or Manipravalam texts (the same question is also asked by Wilden 2014: 363, fn. 323). Given the geographical connotations of the manuscript culture under investigation here, one might intuitively expect Tamil to be the mother tongue of scribes and owners (Telugu being an alternative) and hence a viable option for writing the colophon(s) of any manuscripts, regardless of the language of the texts they carry. The data emerging from our corpus confirm such intuition. Tamil colophons are found in manuscripts containing Sanskrit texts (e.g.

5 The spelling 'Manipravalam' is based on the transliteration from the Sanskrit version of the word, i.e. maṇi-pravāla, meaning 'pearl and coral'. Its Tamil version is maṇi-p-piravālam.

6 Additionally, as far as the manuscript culture of nineteenth century Tamil Nadu is concerned, Telugu script can also be used to write both Sanskrit and Manipravalam. 
RE08256), Tamil texts (e.g. UVSL511) and Manipravalam texts (e.g. E00583a). A blending of Tamil and Sanskrit is also not uncommon, ranging from colophons in which the two languages are clearly kept separated (e.g. E00069), to colophons composed in Manipravalam alone (e.g. E00583b). Finally, the distribution of colophons written exclusively in Sanskrit is limited to manuscripts only containing Sanskrit texts (e.g. E00002a).

Often, no matter what language the text contained in the manuscript is composed in, colophons can contain invocations in Sanskrit (e.g. E00009a [14v3] hariḥ om - śubham astu - avighnam astu 'Harih om. May there be prosperity. May there be no obstacle'), in Tamil (e.g. UVSL1080c [25r5] nañrāka 'May there be prosperity') or in both Sanskrit and Tamil together (e.g. EO0003c [18(148)v3-4] hariḥ om - śubham astu [...] yemperumāñār tiruvațikaḷe carañam 'Harih om, May there be prosperity. The holy feet of Emperumānār (= Rāmānuja) are the refuge'). The only case that is not attested in our corpus is that of a manuscript containing a Sanskrit text with invocations exclusively written in Tamil. ${ }^{7}$

Religion also affects the linguistic features of the manuscript culture of Tamil Nadu. Many of the manuscripts under investigation originated in a milieu in which the combination of Sanskrit and Tamil was programmatically intended. In particular, this is the case for manuscripts containing Manipravalam texts, which generally belong to a śri-vaiṣnava context, where the coexistence of the two languages conforms to theological requirements. ${ }^{8}$ Therefore, it is not surprising that in many manuscripts the two languages blend at various degrees, such as in the use of a highly Sanskritised register of Tamil, or in the occurrence of one Tamil invocation in a colophon otherwise fully composed in Sanskrit.

\section{Time}

This section is devoted to the analysis of the dates given in the colophons analysed here. They span more than two centuries, from 1675 (UVSL511) to 1908 (OR2344b). Dates may vary significantly in many respects: the amount of calendar information they include; the system of chronology they use to number the years (or to name them); the sets of names used to indicate months, weekdays

7 The rather limited variety of invocations recurring in our colophons suggests that scribes could draw from a fixed repertoire of formulaic expressions, according to the circumstances. This colophonic feature awaits further investigation.

8 Śri-vaiṣnavism is a form of Viṣnu's cult in which Sanskrit and Tamil scriptures are given the same importance (see Venkatachari 1978). 
and constellations; the language in which they are composed; the script in which they are written; as well as other minor aspects. Yet a certain degree of consistency may be observed, especially with reference to the order in which the elements of time reckoning are arranged in the dates.

As mentioned previously, the amount of information included in the dates varies considerably. At the very least, they are generally made up of three fundamental elements: the year, which is given according either to the Kollam era (see section 4.1.1) or, alternatively, the Jovian sixty-year cycle (see section 4.1.2), the solar month, and the solar day. At their most comprehensive, they include eight different pieces of calendar information: the year according to both the Kollam era and the Jovian cycle, the solar month, the solar day, the weekday, the fortnight, the lunar day (Skt. tithi, Tam. titi) and the constellation or lunar mansion (Skt. nakșatra, Tam. națcattiram). Of these eight elements, the first five are 'solar', since they are calculated on the basis of the (apparent) course of the sun, whilst the last three are 'lunar', that is to say, based on the lunar phases.

In the following sub-sections, each of these eight calendar elements is examined in detail with respect to their meaning, the way in which they are presented in the colophons, the symbols or words that accompany them and so forth. Finally, some conclusions will be drawn, especially about the order of the calendar information included in the dates and the attendant symbols employed.

\subsection{Year}

All the dates under scrutiny are given according to either one or both of the following two systems of annual reckoning: the Kollam era and the Jovian sixty-year cycle.

\subsubsection{The Kollam era}

The Kollam era (Skt. kolamba, Tam. kollamānțu), also known as the Malabar era, is named after the coastal city of present-day Kerala, where it was introduced on 15 August $824 \mathrm{CE}$ (Gregorian dating). ${ }^{9}$ It was, and still is, prevalent in Malabar and in the past was also in use in some southern districts of present-day Tamil Nadu,

9 For a concise but valuable introduction to the Kollam year see Sarma 1996. 
namely Tirunelvēli māvatțam (Tirunelveli district) and Maturai māvatțam (Madurai district), as well as in part of Sri Lanka (Sarma 1996, 93). ${ }^{10}$

The Kollam era is based on a calendar that is solar (or solar-sidereal), current and simhādi (or kanyādi). It is solar, or solar-sidereal, since it is reckoned on the basis of the course of the sun in relation to the position of the 'fixed stars', i.e. the constellations of the zodiac. In this respect, it is contrary to lunar and luni-solar calendars in use all over northern and central India, with the exceptions of Bānlā/Bañga (Bengal) and Oṛisāa (Odisha/Orissa), which are based on the lunar phases. It is current in that the year is reckoned in reference to ongoing years, as opposed to so-called 'expired'-year calendars (e.g. Śaka, Vikrama, Kaliyuga and Bengali San), in which year-numbers refer to the elapsed year, since the first year is counted as 'year zero'. Finally, it is simhādi ('beginning with simha [= Leo]') since the start of the Kollam year coincides with that of the month of Simha, i.e. when the sun enters the zodiacal sign of Simha ('Leo') in mid-August, ${ }^{11}$ as opposed to meșādi calendars in which the beginning of the year corresponds to the month of Meșa ('Aries'), when the sun enters the homonymous zodiacal sign.

In respect of the colophons under investigation, the Kollam year is characterised by three quasi-regular features: it appears as the first element of a date, ${ }^{12}$ it is written in numerical form, ${ }^{13}$ and its year number is preceded and/or followed by a symbol or word specifying that it refers to the Kollam year. ${ }^{14}$ With respect to

10 Geographical names are given in transliterated form followed by their most common English renderings in round brackets.

11 In the northern provinces of present-day Kerala, the Kollam year is kanyādi: it commences one month later than the simhādi, in mid-September, when the sun enters the zodiacal sign of Kanyā ('Virgo') and the month named after it begins. It is only possible to ascertain whether a date is given in accordance with the simphādi or the kanyādi Kollam year if it falls on a day in the month of Simha and if it includes 'additional' elements such as the weekday or the nakșatra, which are necessary for cross-checking. In our corpus only two dates meet these requirements (EO0003a and EO0006 [6v1-2]), both following the simhādi reckoning.

12 The date in E00001 [GL3v1] is the only exception: in fact, it consists of the month, day and Kollam year in this order.

13 The Kollam year is given in words only in RE05920, namely as sahasrādhikașațañcah ('1056'). However, it is worth noting that the compound is incorrect: ${ }^{\circ}$ șatpañcah stands erroneously for ${ }^{\circ}$ șatpañcāssah, and ${ }^{\circ} a d h i k a^{\circ}$ should follow the smaller number, not the larger one. The compound was probably modelled on the version written in numerals: 'thousand plus 56'.

14 Contrary to all other occurrences, in OR2355d the year number is written without any 'identification mark'. In this particular colophon we also find one of two cases (the other is in UVSL1080c) of a Kollam year given in 'abbreviated form', i.e. made up of just the tens and units, and lacking the numerals referring to the century and the millennium: in OR2355d the number '78' stands for '1078', in UVSL1080c ' 48 ' stands for '1048'. It may be noted, however, that both 
the last feature, the following cases are attested in the dates of our corpus: the year number is preceded by the word kollam (see OR2344b), it is followed by a Tamil ordinal marker, ${ }^{15}$ it is both preceded by the word kollam and followed by an ordinal marker, ${ }^{16}$ and it is followed by a symbol (or an abbreviation) for 'year'. In our dates, the symbol for the Kollam year is written in three different styles: an 'accurate form', shaped like a Grantha ligature nna with an added curved line forming a semicircle below it (e.g. E00003a) or a circle around it (e.g. E00069 [63v5]); a soft cursive style (e.g. EO0002a); and an extreme cursive and rounded form very similar to the Tamil/Grantha number ' 5 ' (e.g. EO0001, both at [GL3v1] and $[140 \mathrm{r} 5])^{17}$ or to the Grantha sign for the inherent vowel -e (e.g. in E00006 [GL3v1]). In the appendices to this article, these three forms of the symbol are labelled respectively as $\{\mathrm{YK} 1\},\{\mathrm{YK} 2\}$ and $\{\mathrm{YK} 3\}$. None of these three is found in the lists of symbols and abbreviations available to us, ${ }^{18}$ although the cursive forms $\{\mathrm{YK} 2\}$ and $\{\mathrm{YK} 3\}$ bear a certain similarity with the second abbreviation for 'until' (Tam. varaikkum) given by Pope (1859: 18).

dates appear in multi-text manuscripts in which the complete year number is given in other colophons (namely, OR2355c, OR2355g and UVSL1080a).

15 See 1039 ämta (OR2345) and $1078 m t a($ OR2355c). The term āmta is not recorded in the Tamil grammars and dictionaries available to us. However, âmta is clearly used as a marker in websites /1/, /2/, and /3/ (see webography) to indicate ordinal numbers. Since all three occurrences deal with Tamil matters in Sri Lanka, $\bar{a} m t a$ is possibly a localism. The form $m t a$ can be understood as a variant of $\bar{a} m t a$.

16 See kollam 1066 mtu (OR2340j) and kollam 1078 ämta (OR2355g). The form mtu, which appears to be otherwise unattested, should possibly read $m t a$; for $\bar{a} m t a$ and $m t a$, see the preceding note.

17 This similarity must have confused the compiler of the cataloguing sheet of EO0001; he actually misinterpreted the Kollam year symbol occurring in both dates ([GL3v1] and [14r5]) as a number ' 5 ', with the result that he dated the manuscript to Kollam year 1045 (mistakenly reading '1000', '4', '5') instead of 1004 ('1000', '4', '[symbol]'). There is no doubt that the character under discussion represents the Kollam year symbol, as it is demonstrated both by internal and external evidences. On the one hand, it clearly differs from the number ' 5 ' as it is written by the same scribe elsewhere in the manuscript; on the other hand, it is almost identical graphically to the ' 5 '-ish symbol occurring twice in analogous contexts within dates found in E00006 [GL1r1] and [GL3v1]. In fact, in the case of E00006, such a symbol certainly stands for the Kollam year symbol, at least in the latter date, i.e. [GL3v1], where all the calendar elements consistently point to Kollam year 1006 ('1000', ' 6 ', '[symbol]'), and not to 1065 (as it would if we were to read the disputed character as ' 5 ': '1000', ‘6', ‘5’).

18 Several of the abbreviations discussed in this article are to be found in the lists in Pope (1859: 18), Winslow (1862: 976), Arden (1942: 310) and Grünendahl (2001: 52-54). 


\subsubsection{The Jovian sixty-year cycle}

A Jovian year corresponds to the period of time in which Jupiter travels through one sign of the zodiac (Skt. rāśi, Tam. rāci). This corresponds to one twelfth of the planet's revolution around the sun. Since Jupiter completes its orbit in somewhat less than twelve solar years, one Jovian year is slightly shorter than one solar year.

Two distinct chronological systems based on a cycle of sixty Jovian years have been used in India, or rather in the northern and southern regions of the subcontinent (Pillai 1922 [I.I]: 50-52). ${ }^{19}$ In both systems, each year of the cycle is designated by a specific name. Although the names and their order are the same in both systems, the beginning of the cycle starts in different years in each list (Pillai 1922 [I.I]: 195-196). Furthermore, the definition of the Jovian year given at the beginning of this section applies only to the former (northern) chronological system, so it is not relevant to this particular study. The latter Jovian cycle (Skt. Brhaspaticakra, Tamil Pirakaspaticakkaram) is still used in southern India today and simply consists of a series of sixty solar years (generally called Skt. [bārhaspatya-]samvatsaras, Tamil camvaccarams), each one given a Jovian year name. ${ }^{20}$ In what follows, we only refer to the latter system, since it is the one used in the dates analysed in this article.

The Jovian years are solar and meșādi, that is, they begin on the first day of the month of Meșa, when the sun enters the zodiacal sign of Aries, usually around mid-April in the Gregorian calendar. Since the sixty-year cycle starts anew at the conclusion of the last year of the series, the same year name recurs every sixty years. As a consequence, a date consisting of just the Jovian year, the solar month and the day is ambiguous, in that it recurs every sixty years. ${ }^{21}$

In the colophons selected for this article, the Jovian year appears at the beginning of the date, preceded only by the Kollam year; the Jovian year is always stated by name, followed (but seldom preceded) by a word for 'year' or by a symbol representing it as a Jovian year. Three different words for 'year' are used within this context: samvatsara, varșa and abda. Sometimes the adverb nāma

19 This work is a revised and expanded version of Pillai 1911, as stated by the author himself (Pillai 1922 [I.I]: iii).

20 This convention was current in southern India starting from $907 \mathrm{CE}$, when the periodical suppression of one Jovian year, which was necessary to harmonise the Jovian cycle with the solar years, was abandoned (Renou and Filliozat 1953: 726-727).

21 Six dates of this kind are included in our corpus, i.e. OR2347.1, OR2348, OR2359, RE20020b, RE37121, RE45807. 
('by name') or the adjective nāmaka ('named', 'bearing the name') is inserted between the name of the Jovian year and the word for 'year'.

As in the case of the symbol for the Kollam year, the symbol used to mark the Jovian year also occurs in three variant forms: an 'accurate' form (attested, for example, in RE08256), which is interpreted by Pope (1859: 18) as an abbreviation of the Tamil word varuṣam ('year'); a slightly simplified version of it (found in RE45807 and E00009b [94v4]); and a cursive style variant (as in E00583a and E00583b). In the appendices, these three abbreviated forms have been respectively labelled as $\{Y J 1\}$, $\{\mathrm{YJ} 2\}$ and $\{\mathrm{YJ} 3\}$. Besides these three, however, there are two more variants of the abbreviation as well, labelled $\{\mathrm{YJ} 4\}$ and $\{\mathrm{YJ} 5\}$ respectively, ${ }^{22}$ which are rather puzzling since they correspond to the 'accurate' and the 'mild cursive' forms of the symbol of the Kollam year, i.e. $\{\mathrm{YK} 1\}$ and $\{\mathrm{YK} 2\}$, with the addition of just a single or double upward hook to the upper right. Thus, it appears that at least in some cases the two symbols tend to overlap; whereas the distinction between the symbols/abbreviations for Kollam and Jovian years is clear and unquestionable, when they are written in their respective 'accurate' forms and when they appear within the same date (e.g. E00069 [GL2r5] and EO0009b [94v4]). Their distinctiveness becomes subtler when they are drawn in a cursive style, especially if only one of the two symbols occurs in a date and there is no need to distinguish it from the other year symbol. Generally speaking, the data in our corpus - despite its admittedly limited nature - seem to suggest that a (single or double) curl or knot at the top right of the symbol was characteristic of the Jovian year tags. In RE37121, though, a Jovian year name is followed by what is clearly a Kollam year symbol, whereas the opposite occurs in UVSL511.

As for the names of the Jovian years, they are expressed both in Sanskrit and in Tamil, the Tamil names being derived from their Sanskrit counterparts by being adapted to the Dravidian phonology (e.g. Tamil Piracōrpatti corresponds to Skt. Prajāpati, Cukkila to Śukla, İccura to Îśvara, and so on). The Sanskrit names of the Jovian years are given by Pillai (1922 [I.I]: 195) and Grünendhal (2001: 217-218), and their Tamil counterparts by Pope (1859: 197) and Arden (1942: 317). In the dates under scrutiny, the Jovian years are given with their Sanskrit names (written in Grantha script) in all manuscripts containing Sanskrit texts and in a few containing Manipravalam and Tamil texts, whereas Tamil year names are found in most of the manuscripts containing Tamil texts and in some containing Manipravalam texts (UVSL1080a, UVSL1080c, RE45807 and RE37121). ${ }^{23}$

22 The form labelled $\{\mathrm{YJ} 4\}$ is given by Pope (1859: 18) as an alternative to $\{\mathrm{YJ1} 1$.

23 As noted by Arden (1942: 316), some Tamil Jovian year names are spelt in more than one way; see, for instance, the year name Tāraṇa, always spelt tāruna/dāruṇa in the dates in our corpus (EO0009b [94r3], [94v1], [94v4], and EO0069 [GL2r1 col1], [GL2r5]). 


\subsubsection{The solar (and the lunar) month}

The month is the only chronological element appearing in all the dates under scrutiny, usually right after the information concerning the year(s): ${ }^{24}$ since the Tamil calendar is basically solar, the month referred to in the dates is a solar month as a rule. In manuscripts from Tamil Nadu, solar months are designated either in Sanskrit or in Tamil. In the former, they are named after the signs of the zodiac through which the sun transits, ${ }^{25}$ whereas in the latter case, each name is the (more or less straightforward) Tamil rendition of the Sanskrit name of the lunar month current when the solar month begins, i.e. of the lunar month that began during the preceding solar month (Pillai 1922 [I.I]: 7, 25). ${ }^{26}$ Notably, however, in some of the dates in our corpus, the name of the lunar month is given instead of that of the solar one: Āṣāṭha (in OR2344b and EO0009b [94v1]), Caitra (in RE20020b), Phālguna (in EO0002a). Whenever the lunar month is followed by a number (as in OR2344b, RE20020b and EO0002a), the latter refers to the solar day and not to the so-called 'lunar day' (tithi).

Be they solar or lunar, the names of the months in our colophons are almost invariably followed by a label specifying that what precedes them is the name of a month; ${ }^{27}$ it can be a word (Skt. māsa, Tam. mātam or mācam, 'month') ${ }^{28}$ or an abbreviation, of which there are four different types in our corpus. The first one, which is transcribed in the appendices as $\{M 1\}$, is represented by the Tamil syllable ma with one or more curls to its upper right; according to Pope (1859: 18), this is the abbreviation for Tamil mācam. ${ }^{29}$ The second type, transcribed as $\{\mathrm{M} 2\}$, is

24 E00002 and E00009b [94v1] are exceptions; here, indications of the fortnight and of the weekday respectively have been inserted between the year(s) and the names of the months (a lunar month in both cases; see below). E00001 [GL3v1] is another such case, where the month precedes the day and the year (see fn. 12).

25 From an astronomical point of view, the solar month begins at the samkrānti ('entry into'), i.e. at the moment when the sun enters a new constellation of the zodiac.

26 Lists of the three sets of names (Sanskrit and Tamil for solar months and Sanskrit for lunar months) are given by Pillai (1922 [I.I]: 198); for a more reliable spelling of the Tamil names of the solar months, see Pope 1859: 198 and Arden 1942: 316.

27 Exceptions to this rule are found in EO0009b [94r3] and OR2355d, where the name of the month is not followed by any label whatsoever.

28 In E00069 [GL2r1 col1] the scribe writes prāpte divākare ('when the sun has entered [the month/sign of the zodiac]'); the use of such an elaborate expression in place of a simple word is probably justified by the fact that the scribe composed the colophon in metre.

29 In one instance (RE08256) this abbreviation is followed by the Grantha character ma with virāma (i.e. $m$, the virāma being the sign used for writing a consonant without its inherent short $a$ vowel). 
similar to the Tamil syllable $p u$ (although with the wrong sign for the inherent vowel $u$ ). According to Pope (1859: 18), this is the abbreviation for the Tamil word parru ('received, receipt'), used as a debit sign. ${ }^{30}$ The reason why this abbreviation was employed in manuscript colophons to mark the name of the months is obscure. The third type, transcribed as $\{\mathrm{M} 3\}$, resembles the Tamil ligature tta followed by the Grantha ma with virāma; it is possibly an abbreviation as well, although it is not clear which word it stands for. ${ }^{31}$ The fourth abbreviation, transcribed as $\{$ M4\}, is represented by a Tamil syllable, $m a$, with a full-height ' 2 'shaped sign appended to the right. In both its attestations in our corpus (OR2345 and OR2348), it is followed by the Tamil element cam, forming the Tamil word *m(a)cam (read mācam).

All four abbreviations described above only occur after the name of a solar month and, most notably, only when the solar month is mentioned by its Tamil name. ${ }^{32}$ Despite the limited size of our corpus, the regularity of this pattern is possibly not just a coincidence, but a conscious habit of the scribes, as the date in E00003c seems to suggest. In this colophon, the name of the same month is given twice, with its Sanskrit name (kanyā) specified by the Sanskrit word māsam (written in Grantha script), and with its Tamil name (potțāci, written in Tamil script) specified by the țam-type abbreviation, i.e. $\{\mathrm{M} 3\} .^{33}$

Finally, a remark concerning spelling is occasioned by the data at our disposal. Whilst the Sanskrit names of the months are usually written uniformly and correctly, ${ }^{34}$ Tamil names show a considerable amount of deviation from their standard spelling (as given in Arden 1942: 316): thus, the name of the month Purațāāi (corresponding to Skt. Kanyā) is variously spelt as piratțāci (EO003b),

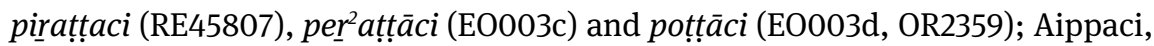

30 'Tamil debit sign (= patru)' is also the definition of the Unicode character U+0BF6, corresponding to this abbreviation (see website /4/).

31 The abbreviations for month in UVSL511 and RE10829 [134v1] are hardly legible, the former due to the poor quality of the digital image, the latter because the writing is uninked. All the same, both of them have been transcribed as $\{\mathrm{M} 3\}$ in the appendices to this article because their first element is a Tamil ligature țta, despite the fact that the following sign is unreadable in both dates.

32 It may be also noted that the Tamil names of months (over thirty in number), which occur in our dates, are followed by an abbreviation for 'month', with only two exceptions: āvaṇi māsam (E00003a) and kārttikai māta (UVSL107).

33 Similarly, in EO0069 and EO0009b, where the date is stated two and three times respectively in a row, the abbreviation for 'month' only appears where the name of the month is written in Tamil (the last date in both colophons).

34 The only exception is kațaka (EO0009b) for Karkațaka (also known as Karka or Karkața). 
or Arpaci, is spelt $a \underline{r}^{2}$ ppaci (EO0583a, E00583b) and $a \underline{r}^{2} p a c i$ (E00069 [GL2r5]); Mārkali is spelt $m \bar{a} \underline{r}^{2} k a \underline{i} i$ (RE37121); Cittirai, Āṇi and Kārttikkai, despite being written correctly in most of their occurrences, are also spelt as cittira (EO0001 [GL3v1]), āni (EO0001 [140r5]) and kārttika (OR2345) or kārtij5 (E00006 [GL1r1]) respectively. It is most probable that what might first seem like idiosyncratic spelling actually reflects the high level of variability that Tamil dialects (or registers) exhibit (see section 4.1.5).

\subsubsection{The solar day}

The solar day, or day of the solar month, is given in most of the dates under scrutiny and always comes right after the name of the solar month (sometimes after a lunar month; see section 4.1.3). Since the solar day is designated by a number, it is in most cases written in numerals. With just a few exceptions, the numerals are followed by a symbol or a word for 'day', by an ordinal marker or by a locative suffix. ${ }^{36}$

The symbol found in our dates stands for the Tamil word tiyati (also têti or tinam), meaning 'date', 'day of the month' (Arden 1942: 310). In the appendices, it has been transcribed either as $\{\mathrm{D} 1\}$, when it is written in the form given by Arden (very similar to the Tamil number '2', sometimes with its horizontal stroke elongated), or as $\{\mathrm{D} 2\}$, where the final horizontal stroke runs along the top-line of the character. A third symbol for 'day' (transcribed as $\{\mathrm{D} 3\}$ ) that seems to be mainly used in manuscripts written in Malayalam script, is found once in our corpus (OR2355c). In place of the symbol for day, in some dates the numeral(s) are followed by the Tamil ordinal marker $\bar{a} m$ or $\bar{a}$, which may be followed in turn by the word tiy(y)ati ('date', 'day of the month') (OR2355d, OR2344b twice). ${ }^{37}$ In one case, the number is simply followed by tiyati (OR2355g), with no ordinal marker interposed. Incidentally, it is worth noting that in some dates (OR2345, OR2348, RE37121) the number of the solar day is followed by the Tamil locative suffix - $t(t) i l$, written in an abbreviated form and characterised by a hook or a '2'-shaped sign added to the upper right of the syllable $t i$ (or, perhaps, $t t i) .{ }^{38}$

35 In shortened form, with the abbreviation being marked with a '2'-shaped curl added at the end of the $-i$.

36 Only the dates of three colophons (UVSL511, RE10829 [134v1] and E00007a) do not present any 'specifying element' after the number that refers to the solar day.

37 The form tiyyati (also spelt tìyati) is the Malayalam counterpart of Tamil tiyati ('date').

38 In OR2355d and OR2355g the sign for the vowel $i$ in the last syllable of tiyati is followed by an ambiguous short horizontal stroke. This may be understood either as an abbreviation for the locative suffix or as some sort of punctuation mark. 
In some dates, the number of the solar day is written out in letters (in the Sanskrit language and using Grantha script); these numbers ${ }^{39}$ are always followed by a Sanskrit noun for 'day': divasa (EO0002a, RE05920), dina (RE10829 [134r5]) or ahan (EO0009b [94r3]).

\subsubsection{The days of the week}

In Indian calendars, the weekdays (Skt. vāra, Tam. kilamai) are named - as in the European tradition - after the sun, the moon and the five main planets: Mars, Mercury, Jupiter, Venus and Saturn. Since they are systematically consistent in both traditions, 'the weekday is the meeting ground of the Indian and European calendars' (Pillai 1922 [I.I]: 14). The names of the weekdays are formed by compounding the name of the relevant 'planet' with a word denoting 'weekday'; in the dates in our corpus, these compounds are either entirely in Sanskrit (written in Grantha script) or in Tamil (written in Tamil script), with two interesting exceptions (see below).

In Sanskrit each of the seven planets is designated by several different names, and so is the weekday associated with it; a useful - although admittedly not exhaustive - list of Sanskrit names of the planets is provided by Sewell (1896: 2). ${ }^{40}$ In our dates, the Sanskrit name of a planet is always compounded with a Sanskrit word for 'day': vāra (EO0006 [GL3v1], MS2.40, RE08256), vāsara (EO0002a, EO0009b [94r3], E00069 [GL2r1 col1], EO0583b, RE05920) or dina (EO0009b [94v1]). It may be noted that dina is also used to mark the day of the month (see section 4.1.4).

In Tamil the names of the planets are followed by the word kilamai ('weekday'). This is only spelt in its standard form in two colophons (RE10829 [134v1] and EO0583a); in its other occurrences, it is variously written as kelamai (E00003a,b,c,d and E00069 [GL2r5]), kelamai (EO0009b [94v4]) or kelame (E00069 [63v5]). Furthermore, the names of the planets also exhibit some variant spellings. Thus, in place of viyāla[-k-kilamai], 'Thursday', we have vyāla ${ }^{\circ}$ (E00003b and EO0003c), and instead of ñâyirru[-k-kilamai], 'Sunday', we have the colloquial form nătti ${ }^{\circ}$ (EO0003a and E00069 [63v5]). A list of the Tamil names

39 Numbers are doubtlessly ordinals in a couple of cases (daśama, E00009b [94r3], and pañcadaśama, RE10829 [134r5]), while in other cases they may ambiguously represent either cardinal or ordinal numbers (saptadaśa, RE05920, and ekādaśa, EO0002a).

40 The list does not include, for example, the term sthira ('fixed', 'immovable') as a name for Saturn, and consequently for Saturday (occurring in EO0583b). 
for the weekdays is provided by Arden (1942: 315) and Pope (1859: 198). ${ }^{41}$ As is the case with names of months (see section 4.1.3), also these variants can be understood as being due to the different Tamil dialects (or registers) used by scribes.

Finally, it is worth noting the two Manipravalam compounds sanikkilamai, 'Saturday' (RE10829 [134v1]), and budhannkilamai, 'Wednesday' (E00583a). They are constructed by appending the Tamil word kilamai, written in Tamil script, to the Sanskrit names of the planets, written in Grantha script: sani, 'Saturn', and budhan (incorrect for budha), 'Mercury', respectively.

\subsubsection{The lunar chronological elements in dates: pakșa, tithi, nakșatra}

Many of the dates in our corpus include references to the pakșa, the tithi and the nakșatra, which are elements of time division based on lunation, or lunar months. In northern India, the lunar month extends between two successive full moons (Skt. pūrnimā, Tam. pūranami), whilst in southern India it ends with the new moon (Skt. amā $\bar{a} s y \bar{a}$, Tam. amāvācai). ${ }^{42}$ These two systems are called pūrnimānta ('ending with the full moon') and amānta ('ending with the new moon') respectively in Sanskrit, and all the dates in our corpus adhere to the latter.

The lunar month is divided in two pakșas ('wings, sides', i.e. 'fortnights [of the lunar month]'): the first fortnight, during which the moon is waxing, is usually called 'bright' since after sunset the moon is above the horizon and illuminates the night; the second fortnight, when the moon is waning, is commonly called 'dark', since after sunset the moon is below the horizon and the night is dark (Sewell 1896: 4). In our corpus, the first fortnight is called sukla, 'bright, white' (E00003c, E00003d, EO0069 [GL2r1 col1], EO0069 [GL2r5]) or pūrva, 'first, former' (RE05920, E00583a); the dark fortnight is termed krșnaa, 'black' (EO0003b, E00069 [63v5]) or apara, 'latter' (EO0583b). ${ }^{43}$ All these adjectives are compounded with, or accompanied by the noun pakșa, which they qualify; in some cases, the Sanskrit compound thus formed is declined by appending to it the Tamil suffixes - $(t) t-i l$ (EO0069 [GL2r5], E00069 [63v5]) or -(t)tu (EO0003b, EO0003c, E00003d).

41 In addition to the Tamil names of the weekdays, Pope also provides the Tamil version of the Sanskrit names.

42 Epigraphical evidence suggests that the pürnimānta scheme was also used in (at least some regions of) southern India until the ninth century CE (Sewell 1896: 4-5).

43 Possibly metri causa (see similarly fn. 28), in EO0009b [94v1] the scribe ingeniously employs the compound valakșetara (for valakșa- or balakșa-itara), 'the other-than-white'. 
A tithi (sometimes called a 'lunar day') corresponds to the time it takes for the moon to move away from the sun by twelve degrees. The starting point of the tithi cycle is the new moon, when the sun and the moon 'dwell together' (this is the literal meaning of the expression $a m \bar{a}-v \bar{a} s y \bar{a}$, otherwise 'night of new moon'), i.e. when they have the same longitude measured from Earth. As the complete cycle extends through 360 degrees, there are thirty tithis in one lunar month. Thus, the lunar month is divided in thirty tithis, fifteen tithis for each pakșa: since the lunar month is a little shorter than thirty days (about 29.5 days), a tithi is a little shorter than a solar day.

As a rule, in our dates tithis are designated by a Sanskrit ordinal number inflected in the feminine gender. Often the Sanskrit feminine endings are replaced by their Tamil counterparts, with a final short $-i$ in place of $-\bar{\imath}$ (pañcami in EO0583b and E00069 [63v5], daśami in E00003b, dvādaśi in EO0009b [94v4], caturddaśi in E00069 [GL2r5], etc.) and - ai (written in Tamil or Grantha script) instead of - $\bar{a}$ (prathamai in E00003c, dvitiyai in E00003d, tritikai in E00583a - probably for tritiyai, in turn from Sanskrit trtīyā). Sometimes the ordinal is accompanied by, or compounded with the word tithi.

Traditionally, three particular tithis are given special names rather than an ordinal number: the first tithi of the lunar month (called pratipad or pratipadā), the full moon tithi (called pūrnimā, paurnimā or pūrnamāsi), the new moon tithi (called amāvāsyā or darśa) (Sewell 1896: 13; Pillai 1922 [I.I]: 198). Of these three, only the name of the full moon tithi is attested in our corpus, in the Sanskritised Tamil form paurnamāvāsai, 'the full moon [tithi]' (E00003a). The tithis from the second to the fourteenth, identified just by their ordinal number, bear the same name regardless of which of the two pakșas they belong to. In order to avoid confusion, these tithis are always mentioned together with the pakșa and/or the nakșatra.

A nakșatra (lit. 'star', by extension 'constellation' or 'lunar mansion') is the twenty-seventh part of the ecliptic and, as an element of time reckoning, it represents the time required for the moon to move through one of the constellations, or lunar mansions. Since it takes slightly more than 27 days for the moon to travel through the whole ecliptic, one nakșatra is a few minutes longer than one day. Each nakșatra is identified by a special name, either in Sanskrit or in Tamil: lists of these names are provided by Sewell (1896: cxiii [table VIII]) and Pillai (1922 [I.I]: 199)..$^{44}$

44 The former gives only the Sanskrit names, whereas the latter also gives the Tamil names, although unfortunately transliterated into Roman script according to an unsatisfactory method of conversion. 
In the dates in our corpus, the great majority of the names of the constellations are given in Sanskrit and are generally spelt correctly..$^{45}$ They are mostly compounded with the word nakșatra, sometimes written as nakșattira with an epenthesis induced by Dravidian phonology (E00003b, E00009b [94v4], E00069 [GL2r5]); occasionally they are compounded with tāraka (EO0009b [94r3]) or târa (EO0009b [94v1), and, in one single case, the name of the nakșatra alone is given in the locative case (aśvinyām, EO0069 [GL2r1 col1]). In a small number of dates the nakșatra is mentioned by its Tamil name, always in a nonstandard spelling: āyilliya for Āyiliya (RE10829 [134v1]), anuṣam for Anuṣam (E00006 [GL3v1]), avuțta for Avițta (EO0003a). The last two names are followed by the word nakșatra/nakșattira.

\subsubsection{Other elements of time reckoning}

In addition to the principal elements of time reckoning surveyed in the preceding sections, a small number of other time-related terms are mentioned in our colophons.

The colophon at the end of OR2347.1 states that the copying of the text was completed udiccu 13 na ālikaiyār + pottu, 'once [the sun] has risen, at the time of the thirteenth nālikai'. A nālikai (Skt. ghațikā or ghațī), sometimes called the 'Indian hour', is the sixtieth part of a day, corresponding to 24 minutes. As a rule, ghațikās/nālikais are counted from sunrise to sunrise, as is clearly the case in this colophon ('once [the sun] has risen...').

In the date in EO0002a, mention is made of uttarāyana, the 'northward path [of the sun]', which begins with the Makara samkrānti (mid-January) and ends with the Karka[țaka] saṃkrānti (mid-July), when the dakșiṇāyaṇa ('southward path [of the sun]') begins (Sewell 1896: 9).

Finally, words or expressions with broader temporal meanings occasionally occur in our colophons - e.g. utaiyattil, 'at dawn' (E00004), udiccu, '[the sun] being risen' (OR2347.1) -, most notably when they are prompted by metrical ingenuity: tārunābde gate bhānau, 'when the sun has entered the [Jovian] year Tāruṇa [= Tāraṇa]' (E00009b [94r3]), and tulām prāpte divākare, 'when the sun has entered the [Jovian] year Tulā' (EO0069 [GL2r1 col1]). ${ }^{46}$

45 The only exceptions are aśvanī (MS2.40) and aśvatī (EO0069 [GL2r5]), both incorrect for Aśvinì.

46 Both examples are lines of eight syllables from anușțubh stanzas. 


\subsubsection{Some observations on the dates}

Some general findings concerning dates can be drawn from an examination of the data collected for this article. It seems clear that the year (Kollam and/or Jovian), the solar month and the solar day are core elements of the dates in our corpus insofar as they appear in almost all of them, whereas the other chronological elements are only given occasionally.

As for the order of the elements in the dates, there are evidently some consistencies. Generally speaking, the data based on solar reckoning come first, followed by information based on the lunar cycle (pakșa, nakșatra and tithi). This order is followed in all but four of our dates. In all the exceptions, the anomaly is represented by the position of the weekday, which is either centrally positioned (EO0009b [94r3] and [94v4], E00583b) or placed after (EO0069 [GL2r1 col1]) the lunar calendar elements. However, it should be noted that the weekday appears together with four lunar elements of time division (tithi, nakșatra, yoga and karaṇa $)^{47}$ in the pañcāngas ('[consisting of] five parts'), i.e. the traditional Indian calendars that are widely used for astrological purposes and for calculating the exact timing of religious festivals, rites and observances (Sewell 1896: 2, 13-18; Renou and Filliozat 1953: 727). Therefore, despite being based on solar calculations, weekdays may perhaps be traditionally perceived as being closely related to chronological lunar elements and for this reason interspersed with them in the dates of the manuscripts.

When examined in further detail, it is clear that in most of the cases, the order of the elements in the dates corresponds to that followed in the previous subsections (see sections 4.1.1-6): Kollam year, Jovian year, solar month, day of the month, weekday, pakșa, tithi, nakșatra. However, variations to this arrangement do occur; some of them can be accounted for, ${ }^{48}$ whereas others cannot. ${ }^{49}$ On the

47 Unlike tithis and nakșatras, yogas and karanas are units of time based on discretionary mathematical calculations. A yoga corresponds to the period of time during which the sum of the motion in longitude of the sun and the moon is increased by $13^{\circ} 20^{\prime}$ (i.e. a twenty-seventh part of the ecliptic). A karana is a subdivision of a tithi; each tithi being divided in two karanas, there are 60 karanas in one lunar month.

48 For example, the irregular position in the sequence of the month in E00009b [94v1], which is placed after the weekday and immediately before the lunar elements, is probably the consequence of metrical requirements; the same holds true for the jumbled sequences of the lunar elements in EO0009b [94r3] and [94v1].

49 At the moment, we are not able to adduce any explanation for the odd sequence in E00001 [GL3v1] (month, solar day, year). 
whole, although this sequence does not represent a pattern without exceptions, at this point in our study we will consider it the standard.

In some of our manuscripts, scribes have recorded either the dates when they began and concluded their work or, in multiple-text manuscripts, the date when each text was finished. We are thus able to calculate how long it took them to copy a whole manuscript or a section of it. ${ }^{50}$ Thus, E00001, which consists of 140 folios, was completed in less than two months (from 4 May to 30 June 1829). E00006, consisting of 52 folios, was written in thirteen days (from 26 August to 7 September 1830). ${ }^{51}$ The fourth text of OR2355 (that is, OR2355d), in thirteen folios, was completed within a day (and on the same day the preceding text was also completed), whilst it took three days (from 12-15 November 1902) to complete the following three texts, sixteen folios in all. Similarly, it took one and a half months (from 17 August to 3 October 1845) to write the 92 folios needed for the second, third and fourth texts that were included in E00003 (EO0003b,c,d). ${ }^{52}$ Finally, it took a remarkable period of five entire years (from 5 November 1824 to 15 November 1829) to complete the copy of the Aștāadhyāyi in E00069..$^{53}$ It is not possible at this stage of research to draw conclusions about the average time employed by scribes to write a given number of folios. However, it is worth pointing out that once a larger amount of similar data has been gathered, these pieces of information may help us understand the temporal features of manuscript production more fully.

The conversion of the dates found in the scrutinised manuscripts into their equivalents in the Gregorian calendar is based on Pillai's Indian Ephemeris (1922 [VI] and 1923). As already noticed (see section 4.1.2), dates consisting of just the Jovian year, the solar month and the day of the month do not point to a unique day, since they recur every sixty years. Among their possible equivalents in the Gregorian calendar, only the more plausible are given in the table in Appendix. The date in UVSL107 is not precise to the day, since it only consists of the Kollam year and the solar month. Among the other dates, three contain contradictory

50 Although bearing two dates each, the manuscripts EO0007, EO0583 and RE10829 are not relevant here, because their dates were written by different scribes.

51 The scribe also kept a record of the day on which the manuscript was entrusted to the person who had commissioned it, on 26 November 1830.

52 More specifically, it took forty, eight and two days to write 61, 19 and 12 folios respectively.

53 It appears that the scribe who copied this manuscript (Venikațācārya, son of Ranigācārya) was very active: he wrote four of the manuscripts included in the present study (EO0002, EO0003, E00007, EO0009), each of them consisting of over one hundred folios. In the same period of time when he was writing the Aștādhyāyĩ in EO0069, he completed a copy of the Rāmāyaṇa in about 300 folios, the colophon of which is not included in this article (EO0083, completed in $1828 \mathrm{CE}$ ). 
data. In EO0009b [94v4] the year Kollam 1000 is at odds with the other chronological data in the date (Jovian year, solar month and day, weekday, tithi and nakșatra), which consistently point to the tenth day of the month Karkațaka in the Kollam year 999; ${ }^{54}$ in RE05920, the solar day, tithi and nakșatra point to 30 December (1880), whereas the weekday and the pakșa indicate the day after that, 31 December (the day of the new moon); in E00583a, the solar day, weekday and nakșatra point consistently to 4 October (1738), but the tithi given in the date (i.e. the third) instead indicates 5 October. If the discrepancies in the former two cases remain unclear, in the latter case, we can reasonably assume that the date corresponds to 4 October, since it is most probable that the tithi mentioned by the scribe is what Pillai (1922 [I.I]: 5) calls 'the following day's tithi'. In fact, we can assume that the scribe completed the manuscript after 11am on 4 October, i.e. after the end of the second tithi. Conventionally, in colophons one finds the tithi current at the sunrise of the day on which the manuscript was composed - the second tithi in this case. However, here the scribe recorded the tithi current at the very moment in which he completed his work, i.e. during the third tithi.

\section{Space}

In this section we will consider how fraught it is to establish the geographical coordinates of a manuscript based on the information found in its colophon alone, since this can at times put the whole process of location in jeopardy. Explicit mentions of place names are generally lacking in colophons, and, in almost all cases, these should not be related to the manuscripts themselves, but rather to their scribe, their owner or the divinity praised in their invocations.

\subsection{Explicit and loose references to place names}

There are, of course, rare, exceptional manuscripts, in which place names are explicitly mentioned. For instance, UVSL1080a and UVSL1080c respectively state tirunelveliyil eluti muṭittatu [30v6] ('It was fully written in Tirunelvēli') and kumāreț̣u tirunelvēliyil elutiyatu [25r4] ('Kumārețțu wrote in Tirunelvēli'). Here, it

54 The Kollam year 1000 begun either 22 days later than that, if this date follows the simhādi reckoning (see section 4.1.1), or 53 days later, if it is given according to the kanyādi reckoning. 
is evident that the place where the manuscript was written - or at least finalised - was Tirunelvēli (Tirunelveli).

However, one can also find random occurrences of place names, the relevance of which is rather difficult to evaluate in terms of establishing a manuscript's provenance. For instance, RE10829 mentions the name tiruvaiyāru [134v1], which corresponds to a town located in the Tañcāvūr māvatțam (Thanjavur district), approx. $13 \mathrm{~km}$ North of Tañcāvūr. It seems plausible that there might be a direct link between the manuscript and that location. But what kind of link? Can we assume that Tiruvaiyāru (Thiruvaiyaru) was the place where the manuscript was produced? Or the place where it was stored? Moreover, how can we ascertain that the manuscript was not moved from one place to another over the course of time? In this particular case, the position of the name tiruvaiyāru in the colophon might be of assistance. In fact, it was incised, presumably in the same hand, immediately after the date of production of the manuscript. One might then assume that Tiruvaiyāru was the place where the scribe was writing, or at least completed, the manuscript. However, such a reconstruction of the whereabouts of the manuscript should only be taken as an educated guess.

\subsection{Places of scribes and owners}

In most of the colophons, place names accompany the names of scribes and owners. Therefore, they could varyingly refer either to their birthplace, the place from which their family (supposedly) originates or their place of residence at the time of writing. Which one is meant is not easily ascertainable. As a consequence, it is rather difficult to establish whether these locations have anything to do with the place of production or storage of the manuscripts.

One striking case is that of RE05920, which gives the name of its scribe as cucīndiram nārāyaṇar putran senāpati [89v1], 'Senāpati from Cucīndiram son of Nārāyaṇar'. As reported by Varadachari (1986: 201), Cucīntiram (Sucīndiram) is a town in the Kannniyākumari māvațtam (Kanyakumari district) with an important temple. However, Varadachari also reports, without further explanation, that the manuscript is from Tirunelvēli (Tirunelveli). If the latter information is correct, one must draw the conclusion that the place of origin of the scribe had no connection with the location in which the manuscript was produced and/or stored. Such a discrepancy clearly shows the limits of our present enquiry.

An important consideration to keep in mind when trying to locate any of the places mentioned in colophons on a map is that the available information about them can sometimes be ambiguous; the same name can refer to more than one 
place. The graphic representation of the same toponym is liable to significant variations, not to mention that place names can change over the course of time. In this respect, the case of RE45807 is complicated, since it states that icalimatai kopālakṛṣnan elutinatu [36r2], 'Kopālakṛṣṇan from Icalimațai wrote [the first chapter of the Nāmalingānuśāsana]'. There are two villages in the Virutunakar māvatțam (Virudhunagar district) that could correspond to Icalimațai: one is actually called Icalimațai (Isalimadai) and is found in the Kāriyāpațị vațtam (Kariapatti taluk), while the other is called Icali (Isali) and is found approx. $5 \mathrm{~km}$ to the East in the Tirucculi vațtam (Tiruchuli taluk). Both are found approx. 40-45 kms Northeast of Virutunakar, the district headquarters. ${ }^{55}$ The former village would be the best candidate if it were not for the fact that the latter village is also sometimes called Icalimațai (Isalimadai) in some official documents recently issued by various Indian national authorities (see websites /5/ and /6/). It is, therefore, difficult to establish which one of the two villages the scribe, Kopālakṛ̣̣nanan, was from.

Owners are rarely mentioned in our corpus when one compares them to scribes. The only case in which an owner's name is accompanied by a place name is that of RE22704, where the relationship shared by the two is characterised rather precisely. In fact, a form of the verb pira-ttal ('to be born') is used to state that the town of Pālayañkoțtai (Palayamkottai), in the Tirunelvēli māvatțam (Tirunelveli district), is the birthplace of the owner of the manuscript: vellankolli $k u$ runātayyan yelutinatu pālayañkoțtai pir $\underline{r}^{3} a n d a$ pațaravarkalukku [79r7-8], 'Veḷaṅkoḷli (?) Kurunātayyañ wrote [this manuscript] for Paț̣aravarkal, who was born in Pālayañkoț̣ai'.

\subsection{Gods, shrines and place names}

A further category of place names found in colophons concerns particular divinities and the location of their shrines. In most cases, geographical information can be indirectly deduced from the name of the deity praised in the colophon. At times, gods and goddesses are, in fact, referred to by names corresponding to one of their particular forms, the veneration of whom revolves around a specific location, e.g. a temple. RE20020b, for instance, states sahāyadāmnisametaśritanun-

55 The same manuscript also contains another colophon, composed in Telugu, where the same location is mentioned as Śalimada, and the name of another town is reported, i.e. Pālavanattam [205v2-4]. The latter is a village in the Virutunakar district, approx. $40 \mathrm{~km}$ Northeast of the district headquarters. Courtesy of R. Satyanarayan. 
ātheśvarasvāmine namạ [6v3] 'Honour to the image (svamin) of Lord Śritanunātha together with Sahāyadāmnī'. Tanunātha and Sahāyadāmnī, in Tamil Tañunātar and Cakāyavalli ('She with a garland as companion'), are the names of the installations of Śiva and his wife as worshipped at the Tirumēninātar temple of Tirucculi (see website /7/). ${ }^{56}$

Therefore, it is possible to assume that mentioning the divinity venerated at a particular place was in keeping with the activity or devotional practice of the scribe or with that of the commissioner/owner, assuming that the latter had asked to have that specific invocation in the manuscript. In other words, locations and manuscripts might have been linked intellectually as well as devotionally (if one is to assume a difference between these two categories). What precisely does this mean? Were those manuscripts part of private collections belonging to specific individuals who resided in those places? Or did they belong to individuals who were simply devotees of the divinities worshipped there? Or did those manuscripts belong to local institutions? Unfortunately, at present, it is impossible to establish in any precise terms exactly what the link was between the manuscripts and the places mentioned in their colophons. One might, however, postulate that the references are not just random.

\subsection{Some final remarks}

Spatial data contained in colophons are generally characterised by a certain degree of ambiguity. In fact, as seen above, they usually do not allow researchers to ascertain where exactly a manuscript was produced and/or stored. There are, however, a number of alternative scenarios besides such a depressing impasse.

First of all, one should remember that a quantitatively meaningful database is yet to be built. If a particularly telling colophon were to be found, it could provide us with precise spatial data to be cross-checked with the partial information found in one or more other manuscripts, thus casting new light on the geographical coordinates of the manuscript(s). Furthermore, if cataloguing information were more easily searchable, i.e. digitised, it might be possible to cross-check the spatial information contained in, say, one colophon with a whole set of data

56 Note that Tiru-mēni-nātar is the literal Tamil equivalent of the Sanskrit term Śri-tanu-nātha, whilst Cakāya-valli is the equivalent of Sahāya-dāmnī. Also note that Varadachari (1990: 312 and passim) still locates Tirucculi in the Irāmanātapuram māvaț̣am (Ramanathapuram district). In 1987 this was, however, split into several areas: its eastern part was joined to the then Karmavirer Kamarajar district in order to form the Virudhunagar district of today (see website /8/). 
emerging from the material analysis of manuscripts. If we were to match the length of palm leaves, the number of lines per folio, etc. with one manuscript containing precise spatial information, we could potentially locate and characterise centres of manuscript production. Finally, one cannot forget that the institutions in which manuscripts are stored today can in certain cases hold records about where items were purchased or about their donors.

Another line of enquiry might be to make use of the linguistic data found in colophons. Data concerning features characteristic of peculiar dialects or registers of Tamil (such as those collected in sections 4.1.3 and 4.1.5) might prove to be particularly helpful in locating manuscripts. However, to the best of our knowledge, there are no publications in which those features of Tamil are dealt with comprehensively and exhaustively. ${ }^{57}$

Knowing that these research strands must wait for the more or less foreseeable future, the attentive reader might ask what can be done with the available data at present. Our answer is that, owing to their nature, data found in colophons can be used to address a set of questions that does pertain to spatial localisation. For instance, colophons can inform us about the religious milieu in which a particular manuscript was produced. In some cases, one can directly link such a manuscript to a particular divinity, whose image is worshipped at a specific temple, hence at a specific location. Once again, this does not mean that the manuscript was necessarily produced or stored there, but that, for its producers and users, it bore an intellectual and devotional association to that particular place. This kind of perusal would help trace the distribution of particular texts within the territory under consideration and also help us understand the dynamics of knowledge exchange that occurred there.

Furthermore, colophons can inform us about the place to which scribes and owners associated themselves, i.e. either their birthplace or the place of origin of their families, or, indeed, the place where they resided. As mentioned previously, this sort of information does not automatically provide us with an exact map indicating the locations of activity of individuals who were interested in manuscripts. However, such information can be cross-checked with what is already known about the religious - and possibly also social and economic - geography of Tamil Nadu and the surrounding areas and, where available, with other spatial data contained in the colophon(s) of the same manuscript. This operation would

57 Partial data can be found in a small number of publications. See, for instance, Burnell 1880: 132 for a list of publications on Tamil dialects from the same author, and Zvelebil 1959, 1960 and 1963. 
help us to contextualise the places mentioned in the names of scribes and owners.

An example may help to clarify what might be the outcome of our proposed approach. E00006 contains, as Varadadesikan noted in his cataloguing sheet, 'The work 'Amalañātipirāñ' [that] consists of ten hymns sung by Tiruppāṇālvār in praise of the Lord Ranganatha in Srīrangam. This work is a commentary on those hymns'. From the information found in the colophons of this manuscript, we can hypothesise about the dissemination of its text within a particular area of Tamil Nadu, namely the Tūttukkuți māvațtam (Thoothukudi district). In fact, one of the colophons mentions the owner of the manuscript as Tirukkurukai Perumāl, where Kurukai is a variant name for Âlvārtirunakari. Furthermore, a certain Ālvārtirunakari Criperiyanampi is also mentioned as the person who produced a new copy of E00006. Allvārtirunakari (alias Tirukkurukai), to which both the owner and copyist are linked either in terms of devotion or of family affiliation, has a temple called Ālvārtirunakari Perumāl (Alwarthirunagari Perumal), which is one of the Navatiruppati (Nava Thirupati), i.e. the nine temples dedicated to the cult of Viṣnu found in the Tūttukkuṭi māvațtam. Interestingly, a man named Critirukkumarar Kaḷlappirān Aiyyañkār is also mentioned as the person into whose custody the copy of E00006 was given; it is possible that he was the owner himself. Kallappirān ('Lord of the Thieves') is the form of Viṣnu venerated in another one of the Navatiruppati temples, namely the Vaikuṇtanātar (Srivaikuntanathan Perumal) temple, which is located in the town of Tiruvaikunțam (Srivaikuntam). Thus, we can postulate that this latter individual had some sort of connection to that place, whether anagraphical or devotional. What emerges from these data is the milieu in which E00006 and its text moved, i.e. a network of individuals and places, namely the Navattirupati temples, which were deeply connected to the vaiṣnava cult.

Such an example shows the importance of asking the right questions of the available sources. It also challenges what one might intuitively understand in terms of locating. In fact, here the focus is not on spatial features concerning the production and storage of a particular manuscript, but on the intellectual and devotional context within which the manuscript and its text(s) were circulated and used. Even if collecting data from colophons is not sufficient to give a comprehensive picture of the spatial dimension of a manuscript, it might, however, represent an important step to take towards corroborating and contextualising other available data.

Acknowledgments: We would like to thank R. Satyanarayan, R. Varadadesikan and G. Vijayavenugopal (EFEO, Pondicherry) for their help. We hope to be able to further our collaboration 
with them in future. We would also like to acknowledge the help of Eva Wilden (EFEO/CSMC/NETamil) in providing the images of the Cańkam and Kịlkkanakku corpora, amassed by the Cańkam Project (EFEO, Pondicherry), and also for reading an earlier draft of this article. We are also grateful to Jean-Luc Chevillard (CNRS/NETamil) for providing the images from Varadadesikan's cataloguing sheets of the EFEO manuscript collection, Jonas Buchholz (NETamil) for his help with interpreting the colophons of UVSL1080a and UVSL1080c, and Florinda De Simini (Università degli Studi di Napoli L'Orientale) for providing the image of MS2.40.

\section{Abbreviations, symbols and conventions}

\section{Codicological/manuscriptological/palaeographical abbreviations and symbols}

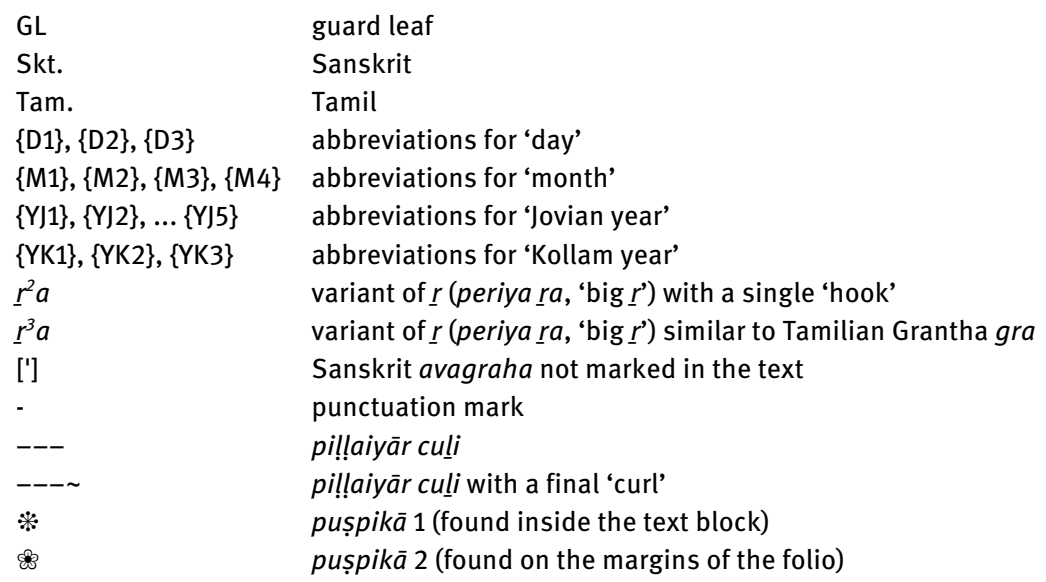

\section{Editorial symbols}

$\begin{array}{ll}\circ & \left.\text { abbreviation at the end of a word (e.g. } t^{\circ}=t t i l, y^{\circ}=y a m\right) \\ {[\mathrm{X}]} & \text { erased graph } \\ {[\mathrm{X}]} & \text { inferred graph } \\ \dagger & \text { crux desperationis }\end{array}$

\section{Brackets in manuscript transcriptions and translations}

[ ] Square brackets are used to indicate the folio number of the manuscript, the folio side and the line number, as in RE05915 [41v3], which should be read as RE05915, folio 41, verso, line 3. If the manuscript has double folio numeration, the one that applies to the whole manuscript is indicated in round brackets, as in E00003d [30(160)r4]. If the folio is not numbered in the manuscript, it is referred to as GL (= guard leaf), as in E00001 [GL1r1]. If the folio is written over more 
than one column, this is specified as OR2355g [65v1 col2]. Square brackets are also used to indicate: Sanskrit avagraha when not graphically represented, as in E00009b [94r3] daśame [']hani; a graph that has been cancelled but is still readable, as in EO0009b [94v4] 1000 [1] \{YK1\}; and a graph that is unreadable (either because it was cancelled or because the folio is damaged). In the latter case, a crossed-out capital X is inserted in the brackets, as in E00009b [94v2] ${ }^{\circ}$ vempkațāryyagu[X]runāa. Finally, square brackets are used in transliteration to integrate graphs that are missing and/or omitted in the original, as in EO0009b [94r3] kațakam given in translation as ka[rka]taka.

\{ \} Curly brackets are used to indicate the symbols and the abbreviations for the Kollam year (\{YK\}), Jovian year (\{YJ\}), month (\{M\}), and day of the month (\{D\}), as in E00069 [GL2r5] $1000\{$ YK1\} tāruna $\{\mathrm{Y} \mid 1\}$ a ${ }^{2}$ paci $\{\mathrm{M} 3\} 22$ \{D1\}. The number included in the curly brackets specifies which variant of the symbol/abbreviation is used; for a description of these variants, see the section on Time above (section 4).

$\checkmark$ / A backslash and slash are used to indicate the portion of the text that the original scribe, or a later one, inserted interlinearly, as in E00009b [94r3] ve $\backslash m /$ kataguru $^{\circ}$. Sometimes, scribes wrote the sign ' + ' in order to mark where the new portion of text should be inserted, as in E00002a [106v7] kāverīmahimā+\†[?]tāt/.

II// A double backslash and slash are used to indicate alternative readings pointed out by the scribe interlinearly, as in E00069 [GL2r3 col1] śrīraṃgarājadāsa svallraṃgarājātmaja svena//kareṇa veṃkațāryyakaḥ, where ramgarājātmaja svena kareṇa veṃkațāryyakaḥ is given as an alternative to (and possibly as an improved version of) śrīraṃgarājadāsa svakareṇa veṃkațāryyakah.

\section{Appendix 1: Table}

All the pictures in the table are taken from digital images, with the exception of those excerpted from manuscripts OR2345, OR2348, RE10829 [134v1], RE20020b, RE37121 and UVSL (all), which have been digitally redrawn due to the poor quality of the original pictures; in particular, the reconstruction of the symbols and the abbreviations found in RE10829 [134v1], UVSL107 and UVSL511 is tentative.

In the table, the entries are given in chronological order. The abbreviations TA, GR and MP stand for 'TAmil script', 'GRantha script' and 'ManiPravalam' (i.e. a mixture of the two), respectively. The abbreviations O. and R. stand for Owner and Recipient, respectively.

Texts are presented in diplomatic transcription. 


\begin{tabular}{|c|c|c|c|c|c|}
\hline $\begin{array}{c}\text { CAT. No. } \\
\text { TITLE } \\
\text { SCRIPT (text/colophon) }\end{array}$ & 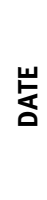 & $\underset{\square}{\breve{a}}$ & 鲇 & $\begin{array}{l}\dot{\alpha} \\
\dot{0} \\
\dot{0}\end{array}$ & Kollam YEAR \\
\hline $\begin{array}{l}\text { UVSL511 } \\
\text { Kalittokai } \\
\text { TA / TA }\end{array}$ & 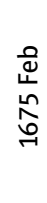 & & & & $850\{Y J 4\}$ \\
\hline $\begin{array}{l}\text { UVSL107 } \\
\text { Akanān̄ūru } \\
\text { TA / TA }\end{array}$ & 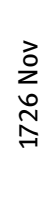 & & & & $\begin{array}{l}902\{Y K 2 ?\} \\
-53\end{array}$ \\
\hline $\begin{array}{c}\text { E00583a } \\
{[\text { GL1v4] }} \\
\text { Tirunakarippil!lai } \\
\text { Rahasyam (?) } \\
\text { GR(?) / MP }\end{array}$ & 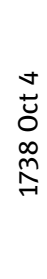 & & & & $\underbrace{\text { TrS }}_{i k}$ \\
\hline $\begin{array}{c}\text { E00583b } \\
\text { [95v8] } \\
\bar{A} \text { Āāryabhakti } \\
\text { [from cat.] } \\
\text { Sārārttharatnamālai (?) } \\
\text { MP / MP }\end{array}$ & $\begin{array}{l}\vec{I} \\
\stackrel{U}{0} \\
0 \\
\infty \\
\\
\stackrel{H}{\sigma}\end{array}$ & & & & $\frac{914\{\mathrm{YK} 2\}}{\sqrt{65}}$ \\
\hline $\begin{array}{c}\text { RE10829 } \\
\text { [134r5] } \\
\text { Vātulaśuddha } \\
\text { GR / GR }\end{array}$ & 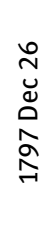 & & & 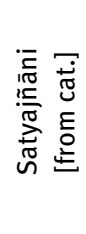 & \\
\hline
\end{tabular}




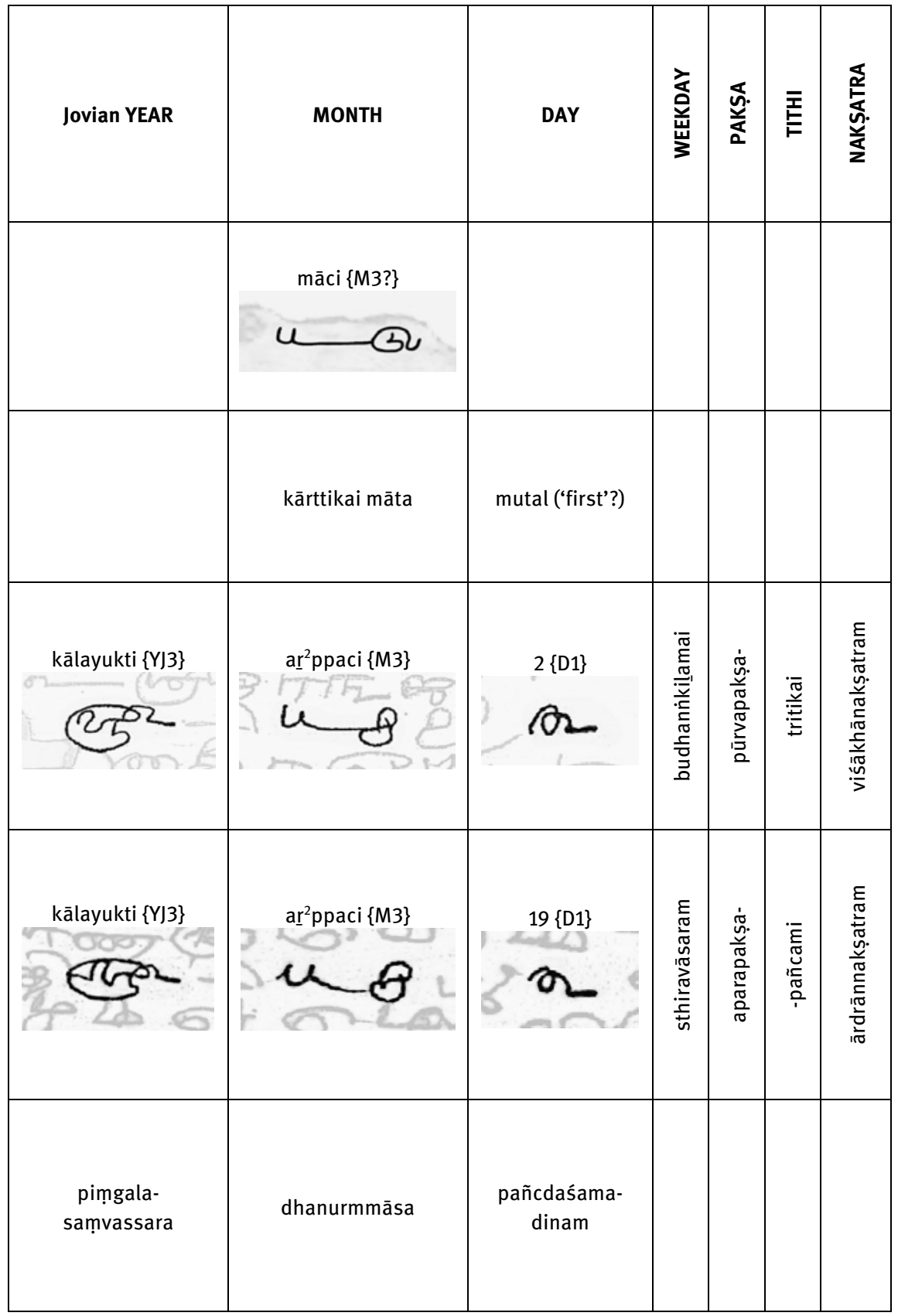




\begin{tabular}{|c|c|c|c|c|c|}
\hline $\begin{array}{c}\text { CAT. No. } \\
\text { TITLE } \\
\text { SCRIPT (text/colophon) }\end{array}$ & 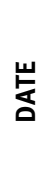 & 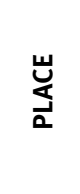 & $\begin{array}{l}\text { 囯 } \\
\text { 쏘 }\end{array}$ & $\begin{array}{l}\dot{\alpha} \\
\dot{0} \\
\dot{0}\end{array}$ & Kollam YEAR \\
\hline $\begin{array}{c}\text { RE10829 } \\
\text { [134v1] } \\
\text { Vātulaśuddha } \\
\text { GR / MP }\end{array}$ & 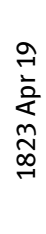 & 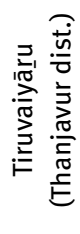 & & & \\
\hline $\begin{array}{l}\text { E00002a } \\
\text { Tulākāverī- } \\
\text { māhātmyam } \\
\text { GR / GR }\end{array}$ & 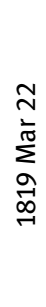 & 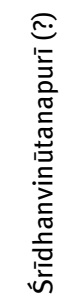 & 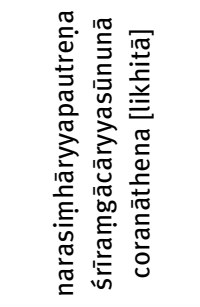 & & $994\{Y K 2\}$ \\
\hline $\begin{array}{c}\text { E00009b } \\
{[94 \mathrm{r} 3]} \\
\begin{array}{c}\text { Śīgunaratnakośa- } \\
\text { vyākhyā }\end{array} \\
\text { GR / GR }\end{array}$ & 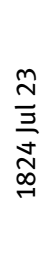 & & 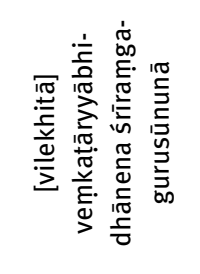 & & \\
\hline $\begin{array}{c}\text { E00009b } \\
{[94 \mathrm{~V} 1]} \\
\begin{array}{c}\text { Srīgunaratnakośa- } \\
\text { vyākhyā } \\
\text { GR / GR }\end{array}\end{array}$ & 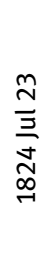 & & 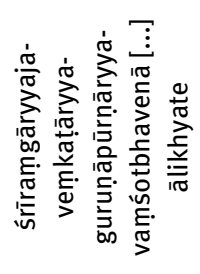 & & \\
\hline
\end{tabular}




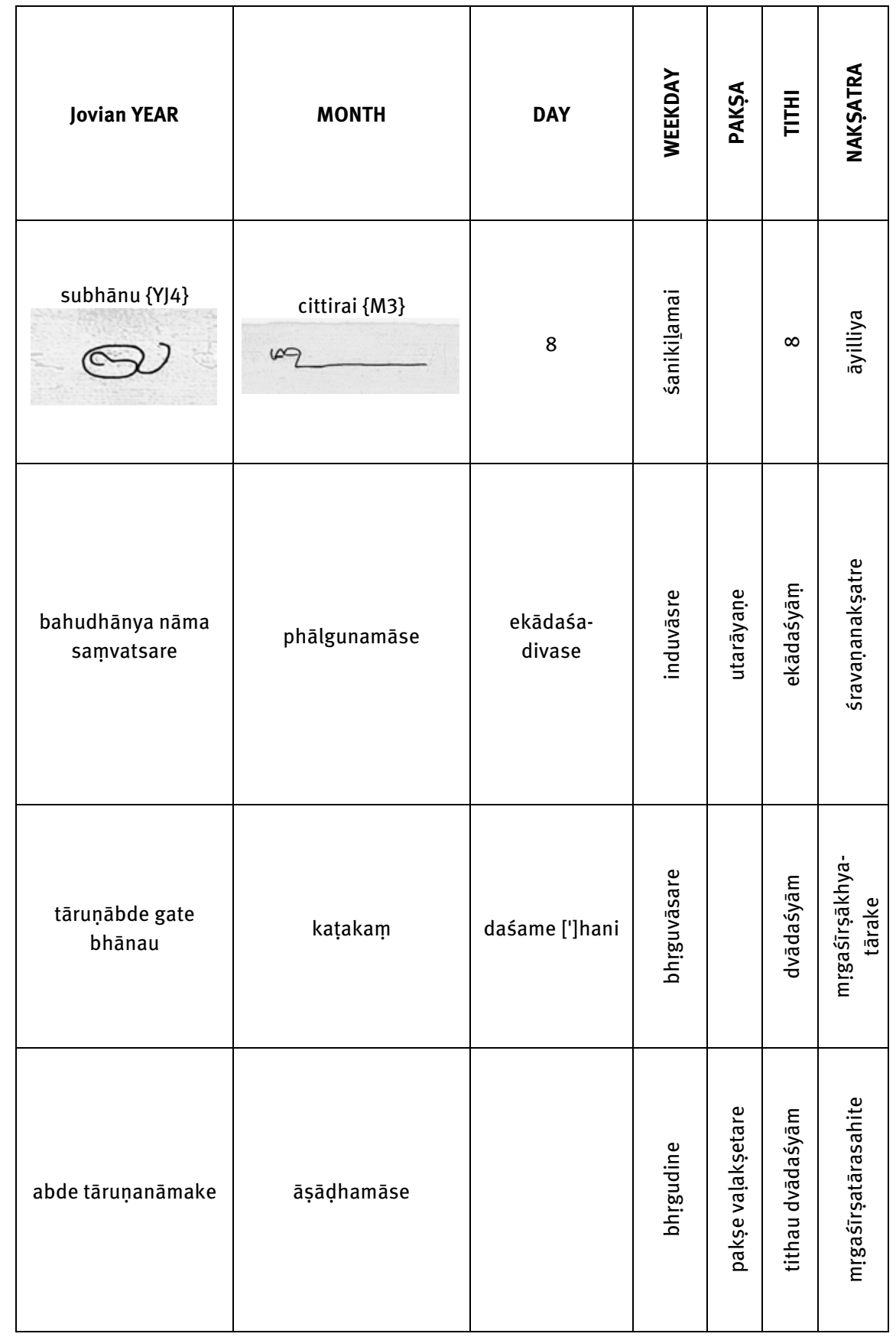




\begin{tabular}{|c|c|c|c|c|c|}
\hline $\begin{array}{c}\text { CAT. No. } \\
\text { TITLE } \\
\text { SCRIPT (text/colophon) }\end{array}$ & 索 & 岁 & $\begin{array}{l}\frac{u}{\underline{m}} \\
\frac{\tilde{w}}{\sim}\end{array}$ & $\begin{array}{l}\dot{\alpha} \\
\dot{0} \\
\dot{0}\end{array}$ & Kollam YEAR \\
\hline $\begin{array}{c}\text { E00009b } \\
{[94 \mathrm{~V} 4]} \\
\begin{array}{c}\text { Srīgunaratnakośa- } \\
\text { vyākhyā } \\
\text { GR / MP }\end{array}\end{array}$ & 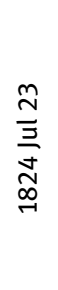 & & 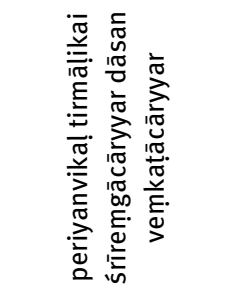 & & बुग \\
\hline $\begin{array}{c}\text { E00069 } \\
\text { [GL2r1 col1] } \\
\text { Asțāâdhyāyī } \\
\text { GR / GR }\end{array}$ & 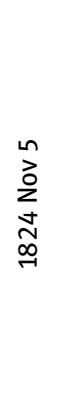 & 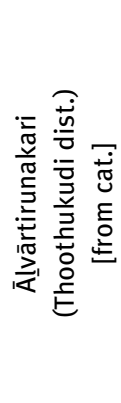 & 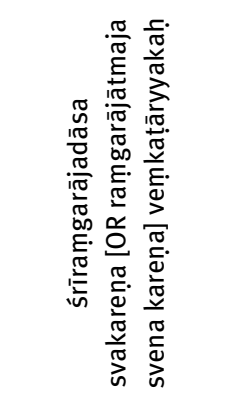 & & \\
\hline $\begin{array}{c}\text { E00069 } \\
\text { [GL2r5] } \\
\text { Așțādhyāyī } \\
\text { GR / MP }\end{array}$ & 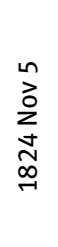 & & 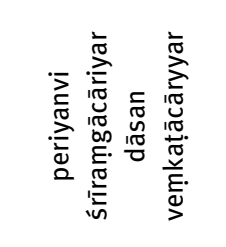 & & बarg \\
\hline $\begin{array}{c}\text { E00069 } \\
\text { [63v5] } \\
\text { Aștādhyāyī } \\
\text { GR / MP }\end{array}$ & 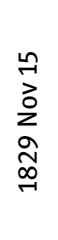 & & 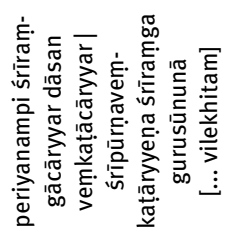 & & कण \\
\hline
\end{tabular}




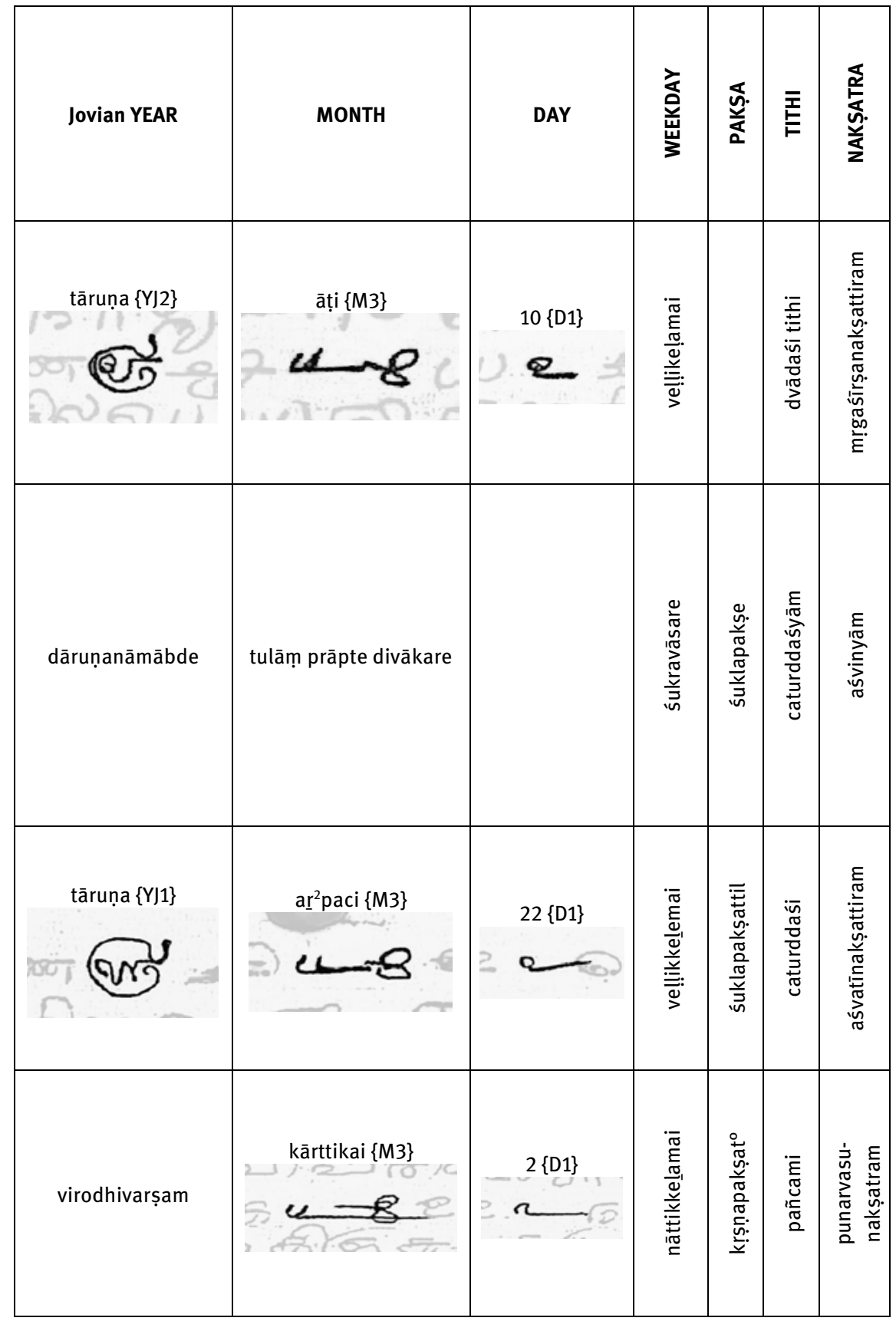




\begin{tabular}{|c|c|c|c|c|c|}
\hline $\begin{array}{c}\text { CAT. No. } \\
\text { TITLE } \\
\text { SCRIPT (text/colophon) }\end{array}$ & $\underset{\frac{\omega}{\sigma}}{\frac{\omega}{\sigma}}$ & 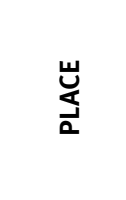 & $\begin{array}{l}\text { 岕 } \\
\text { 씀 }\end{array}$ & $\begin{array}{l}\dot{\alpha} \\
\dot{\vdots} \\
\dot{0}\end{array}$ & Kollam YEAR \\
\hline $\begin{array}{c}\text { RE05915 } \\
\text { Jayantīpuramāhātmya } \\
\text { GR / GR (in TA only ān̄i and } \\
\text { eluti mukiñcutu) }\end{array}$ & 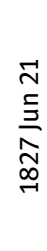 & 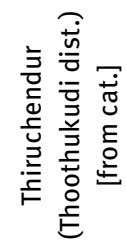 & & & Org \\
\hline $\begin{array}{c}\text { E00007a } \\
\text { Candrāvaloka } \\
\text { GR / GR (in TA only the } \\
\text { word } \bar{a} t+i)\end{array}$ & 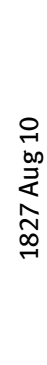 & & 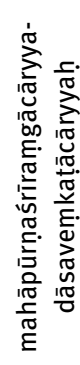 & & 5 \\
\hline $\begin{array}{c}\text { EO0001 } \\
{[\mathrm{GL} 3 \mathrm{v} 1]} \\
\text { Tiruvāymoḷi Nālām Pattu İtu } \\
\text { Vyākhyānam } \\
\text { GR / TA (mostly) }\end{array}$ & \begin{tabular}{l}
+ \\
$\underset{\sim}{\pi}$ \\
$\underset{\sim}{\infty}$ \\
\multirow{-}{\infty}{}
\end{tabular} & & & & $y=$ \\
\hline $\begin{array}{c}\text { EO0001 } \\
{[140 \mathrm{r} 5]} \\
\begin{array}{c}\text { Tiruvāymoḷi Nālām Pattu İțu } \\
\text { Vyākhyānam }\end{array} \\
\text { GR / TA }\end{array}$ & 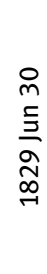 & & & & $\frac{1004\{\mathrm{YK} 3\}}{3}$ \\
\hline
\end{tabular}




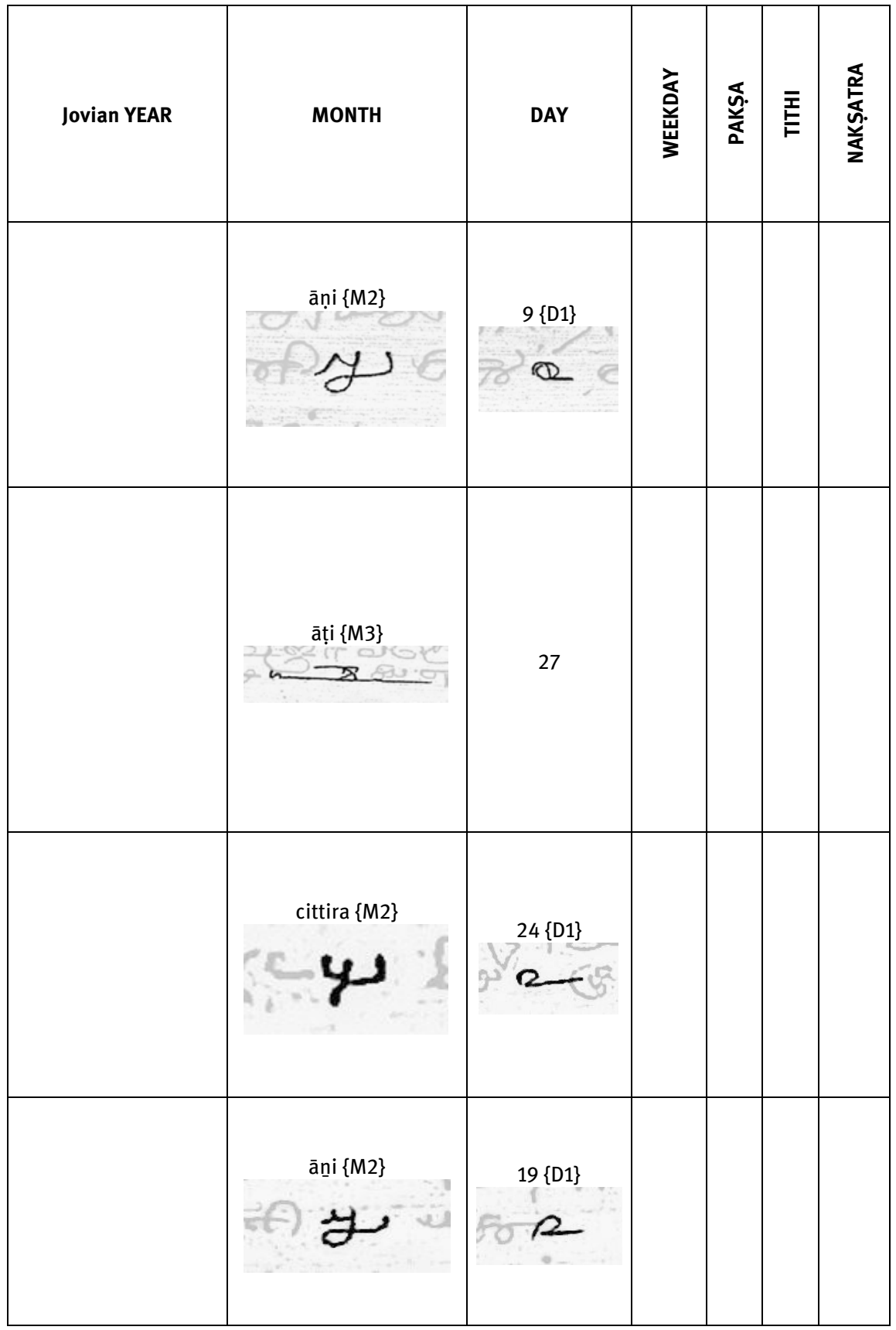




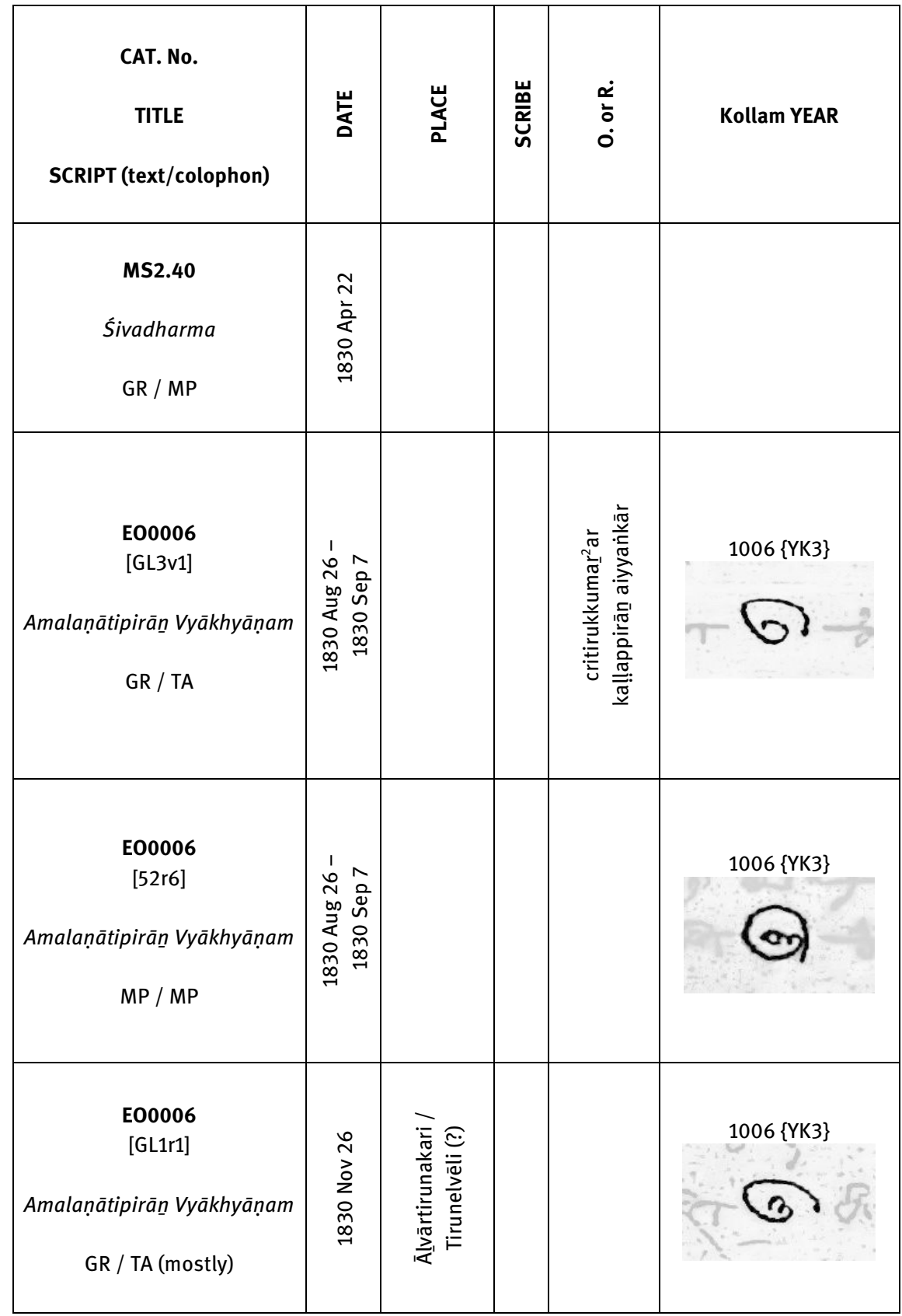




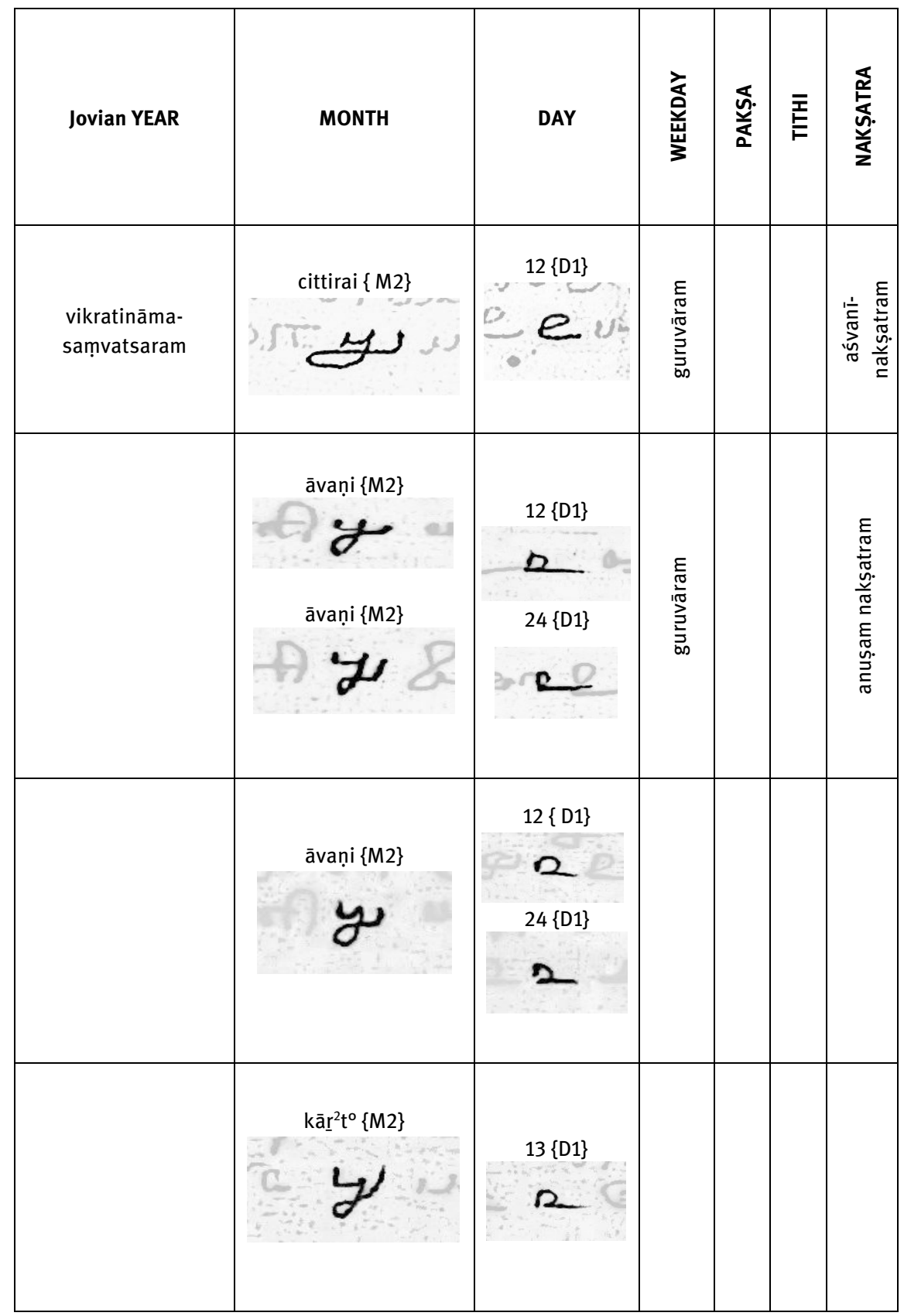




\begin{tabular}{|c|c|c|c|c|c|}
\hline $\begin{array}{c}\text { CAT. No. } \\
\text { TITLE } \\
\text { SCRIPT (text/colophon) }\end{array}$ & 岁 & 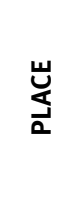 & 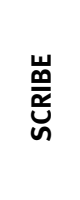 & $\begin{array}{l}\dot{\alpha} \\
\dot{0} \\
\dot{0}\end{array}$ & Kollam YEAR \\
\hline $\begin{array}{c}\text { RE08256 } \\
\text { Sakalāgamasarasamgraha } \\
\text { [from cat.] } \\
\text { GR / MP }\end{array}$ & 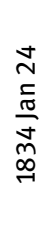 & 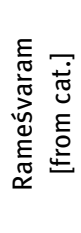 & & & \\
\hline $\begin{array}{l}\text { E00007b } \\
\text { Kuvalayānanda } \\
\text { GR / TA }\end{array}$ & 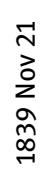 & & & & $\begin{array}{l}1015\{\mathrm{YK} 2\} \\
\text { कु }\end{array}$ \\
\hline $\begin{array}{c}\text { E00003a } \\
\text { Trimśatpraśnottara } \\
\text { MP / MP }\end{array}$ & 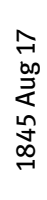 & & 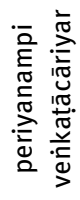 & & $\begin{array}{l}1021\{Y K 1\} \\
\text { CFJ }\end{array}$ \\
\hline $\begin{array}{c}\text { E00003b } \\
\text { Trimśatpraśnottarakhaṇ̣ana } \\
\text { MP / MP }\end{array}$ & 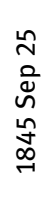 & & 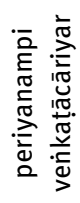 & & IYK2 \\
\hline $\begin{array}{c}\text { E00003c } \\
\text { İtupāṭu of Jīyar } \\
\text { MP / MP }\end{array}$ & 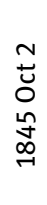 & & 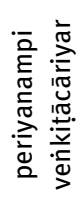 & & $1021\{Y K 1\}$ \\
\hline
\end{tabular}




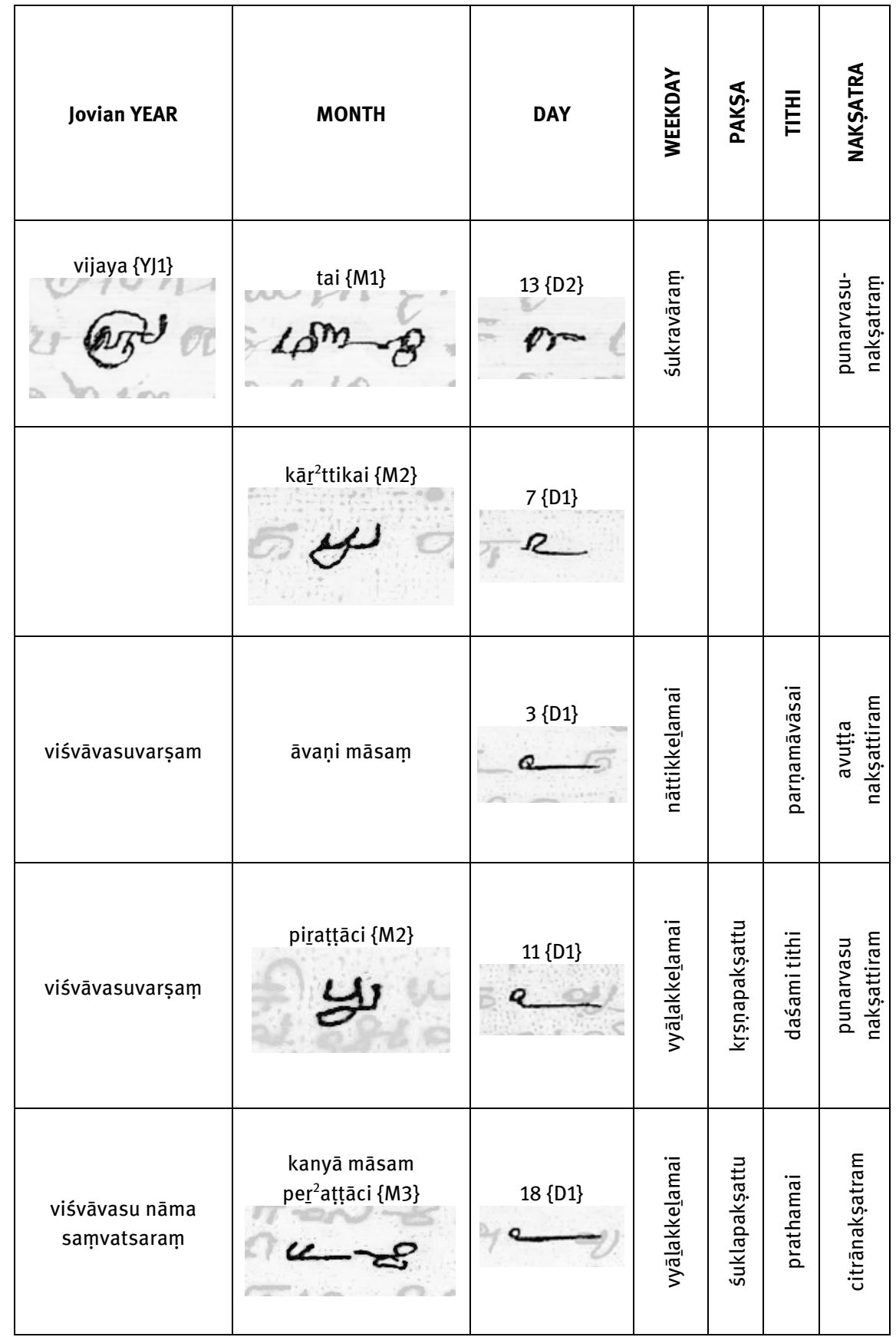




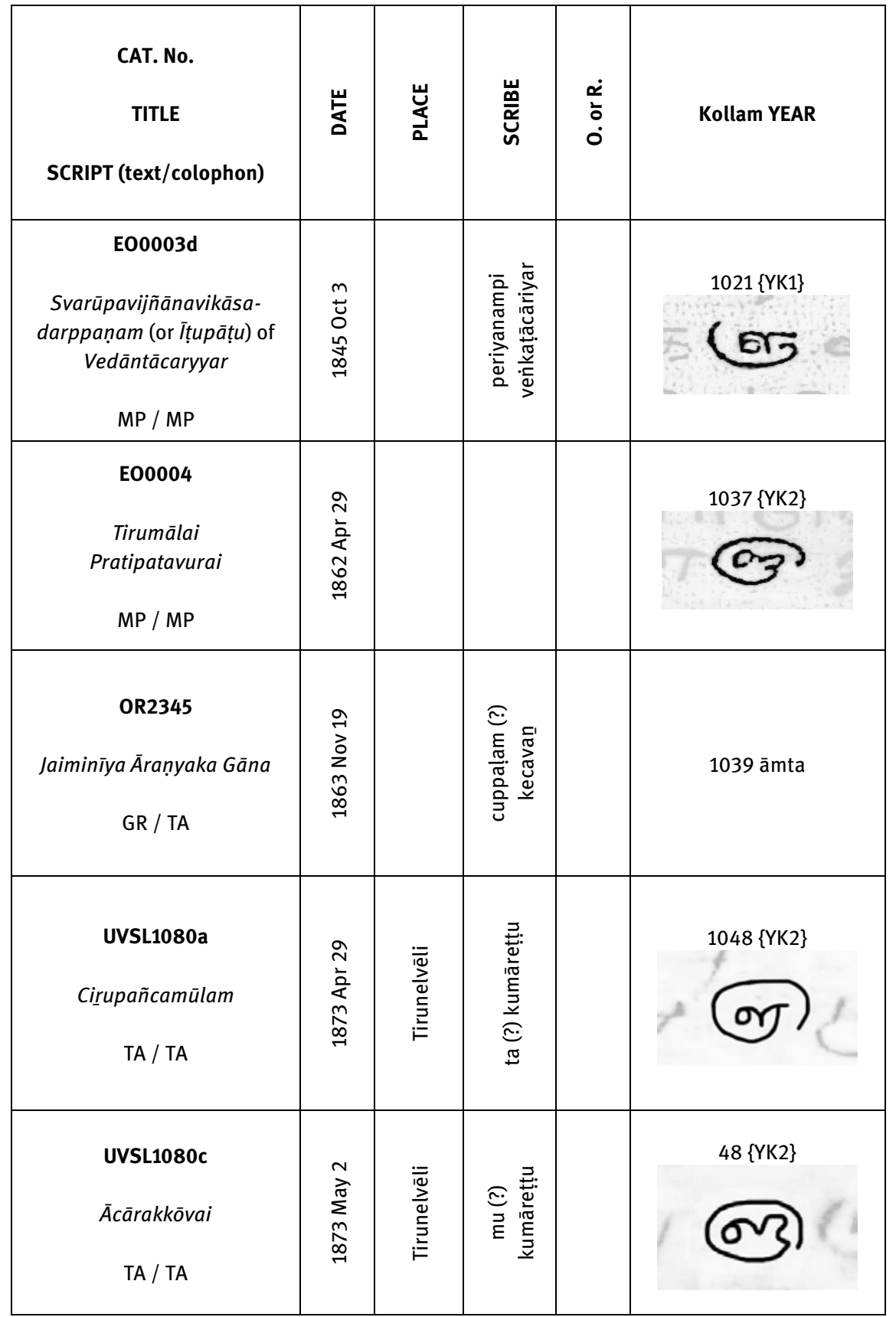




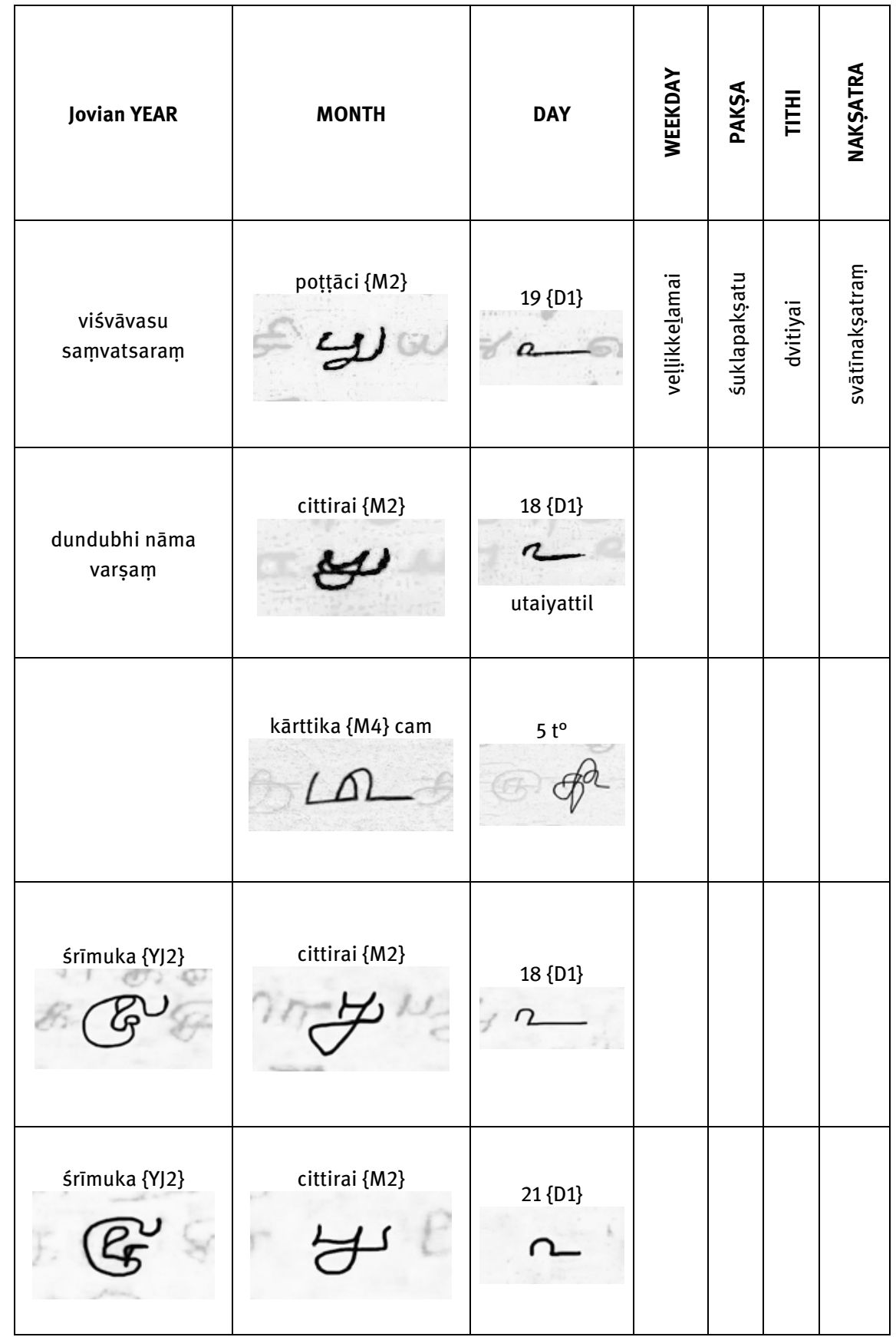




\begin{tabular}{|c|c|c|c|c|c|}
\hline $\begin{array}{c}\text { CAT. No. } \\
\text { TITLE } \\
\text { SCRIPT (text/colophon) }\end{array}$ & $\underset{⿱ ㇒}{\underline{G}}$ & 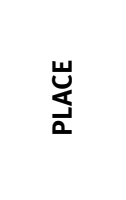 & $\begin{array}{l}\text { 囯 } \\
\text { ㅆّㅁ }\end{array}$ & $\begin{array}{l}\dot{\alpha} \\
\dot{0} \\
\dot{0}\end{array}$ & $\begin{array}{c}\text { Kollam } \\
\text { YEAR }\end{array}$ \\
\hline $\begin{array}{c}\text { RE05920 } \\
\text { Śucīndrasthalamāhātmya } \\
\text { GR / GR (in TA only } \\
\text { sucīndiraṃ) }\end{array}$ & 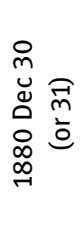 & 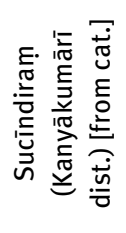 & 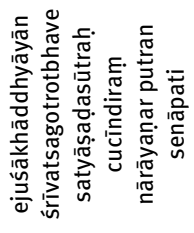 & & 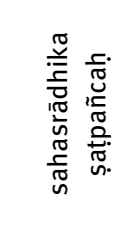 \\
\hline $\begin{array}{l}\text { OR2340j } \\
\text { Șoḍaśīkalyānīstotra } \\
\text { GR / MP (invocations in GR, } \\
\text { the rest all in TA but the word } \\
\text { śāstri) }\end{array}$ & 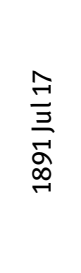 & 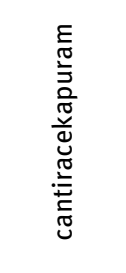 & 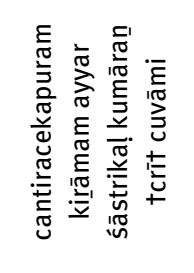 & & $\begin{array}{l}\text { kollam } \\
1066 \mathrm{mtu}\end{array}$ \\
\hline $\begin{array}{c}\text { OR2355c } \\
\text { Pradoșārccana } \\
\text { GR / MP }\end{array}$ & 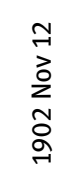 & & & & $1078 \mathrm{mta}$ \\
\hline $\begin{array}{c}\text { OR2355d } \\
\text { R̦șipañcami-vratodyāpana } \\
\text { GR / MP }\end{array}$ & 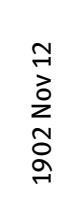 & & 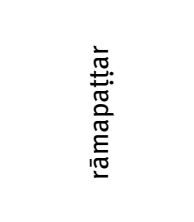 & 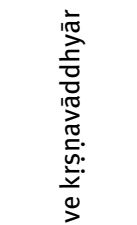 & 78 \\
\hline $\begin{array}{c}\text { OR2355g } \\
\text { Somavārārccana } \\
\text { GR / GR } \\
\text { (in TA only āmata) }\end{array}$ & 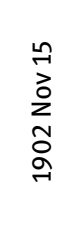 & & 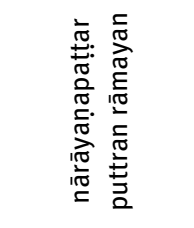 & 离 & $\begin{array}{c}\text { kollaṃ } 1078 \\
\text { āmta }\end{array}$ \\
\hline
\end{tabular}




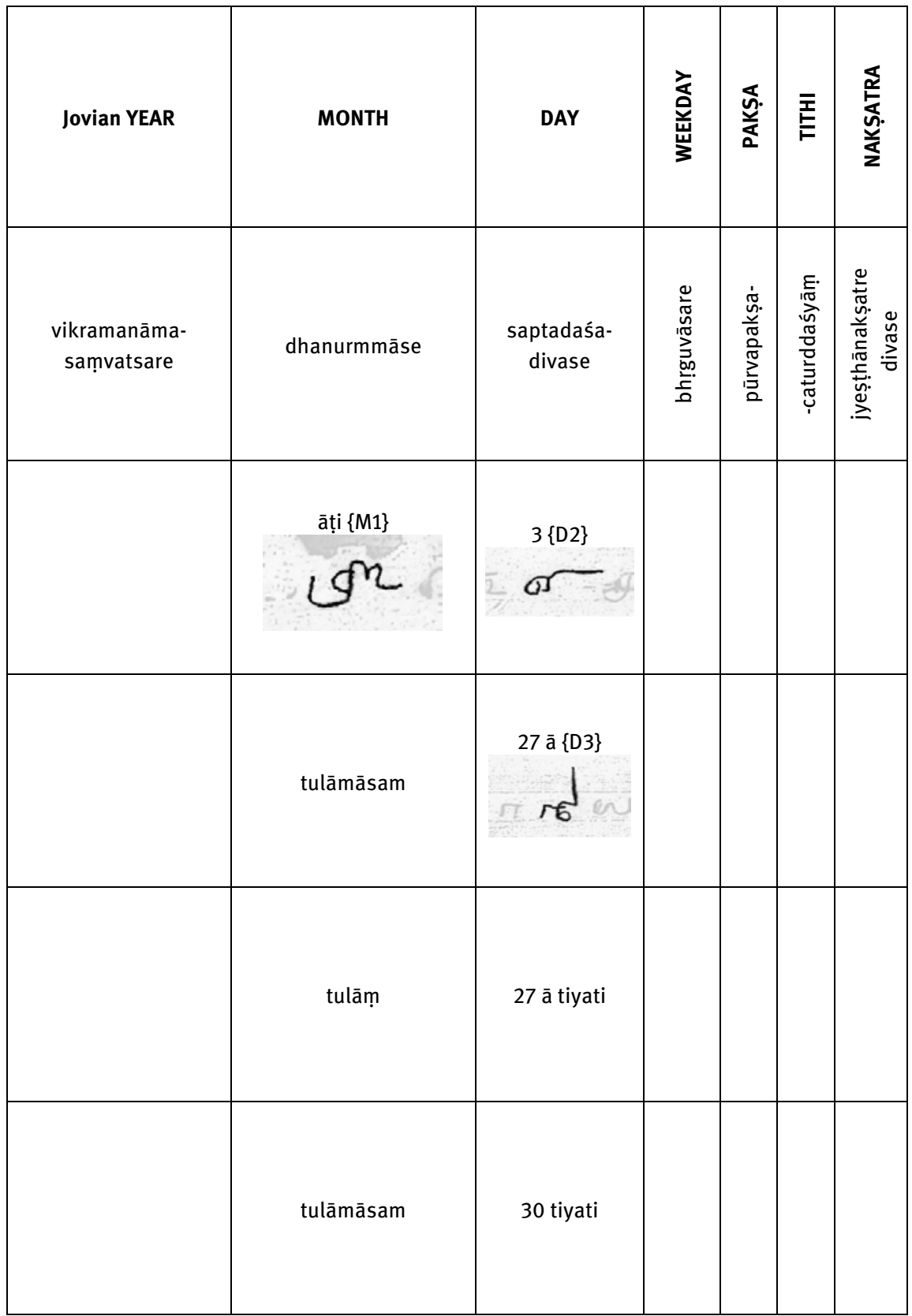




\begin{tabular}{|c|c|c|c|c|c|}
\hline $\begin{array}{c}\text { CAT. No. } \\
\text { TITLE } \\
\text { SCRIPT (text/colophon) }\end{array}$ & $\frac{\omega}{\frac{\omega}{\Delta}}$ & $\underset{\square}{\breve{\Delta}}$ & 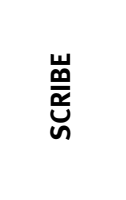 & $\begin{array}{l}\dot{\alpha} \\
\dot{0} \\
\dot{0}\end{array}$ & Kollam YEAR \\
\hline $\begin{array}{c}\text { OR2355h } \\
\text { Nakṣatradevatā rkk } \\
\text { GR / GR }\end{array}$ & & & 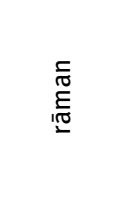 & 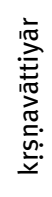 & \\
\hline $\begin{array}{c}\text { OR2344b } \\
\text { Devīmāhātmya } \\
\text { GR / MP }\end{array}$ & 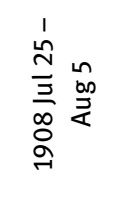 & & 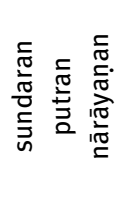 & & kollam 1083 \\
\hline \multicolumn{6}{|c|}{ MANUSCRIPTS WITH AMBIGUOUS DATES } \\
\hline $\begin{array}{c}\text { OR2347.1 } \\
\text { Devīmāhātmya } \\
\text { GR / MP }\end{array}$ & 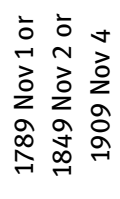 & & & & \\
\hline $\begin{array}{c}\text { RE45807 } \\
\text { Amarakośaḥ } \\
\text { Drāviḍārthasahitaḥ } \\
\text { MP / MP }\end{array}$ & 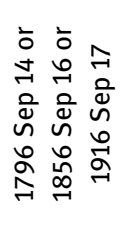 & & 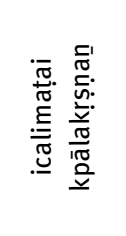 & & \\
\hline $\begin{array}{c}\text { RE37121 } \\
\text { Amarakośaḥ } \\
\text { (with Tamil meaning) } \\
\text { MP / MP }\end{array}$ & 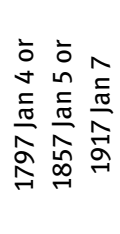 & & 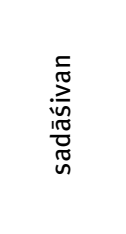 & & \\
\hline
\end{tabular}




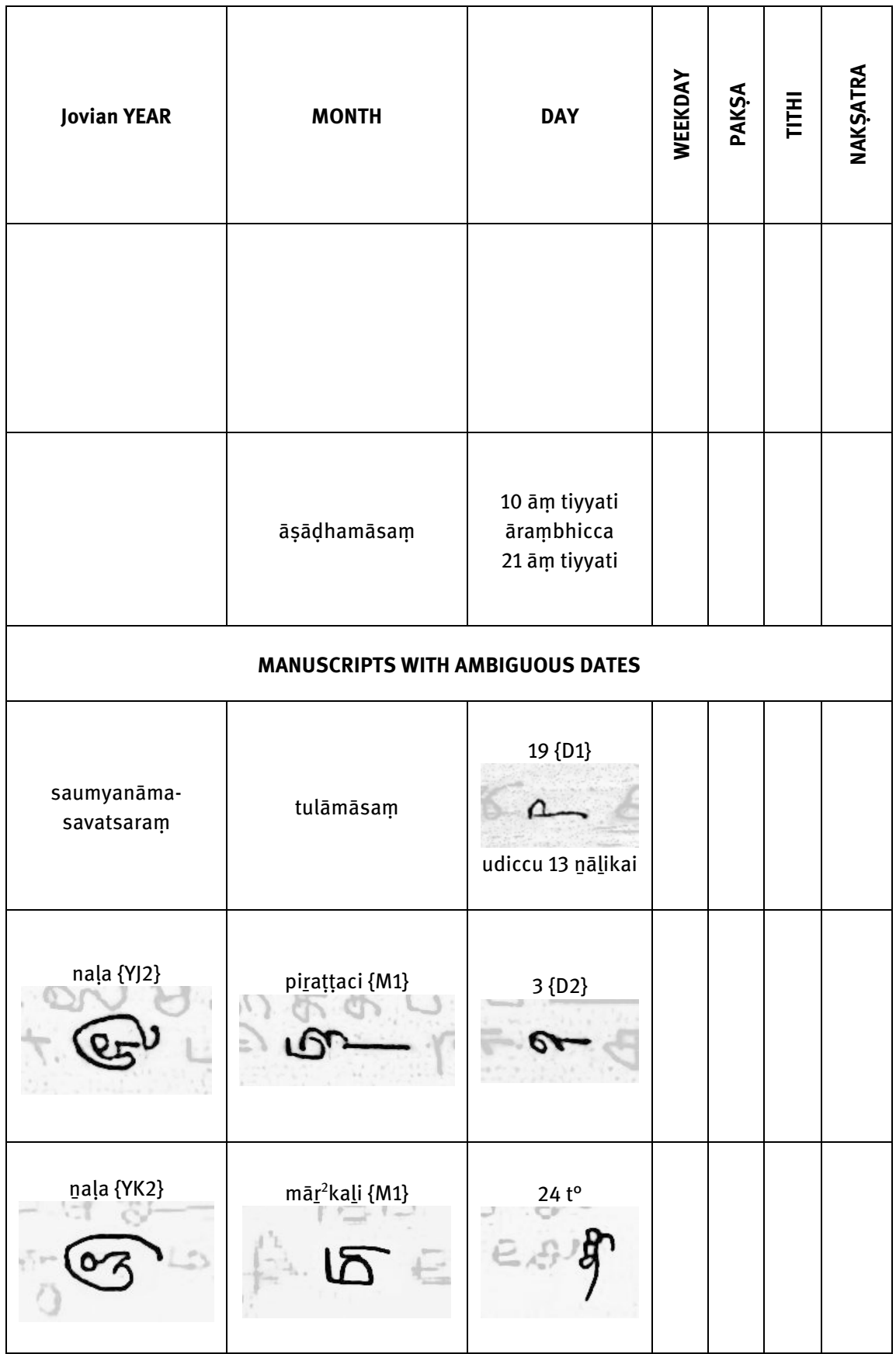




\begin{tabular}{|c|c|c|c|c|c|}
\hline $\begin{array}{c}\text { CAT. No. } \\
\text { TITLE } \\
\text { SCRIPT (text/colophon) }\end{array}$ & 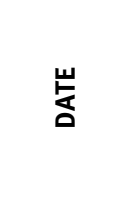 & $\underset{\Delta}{u}$ & 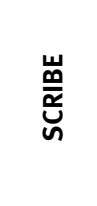 & $\begin{array}{l}\dot{\alpha} \\
\dot{0} \\
\dot{0}\end{array}$ & $\begin{array}{c}\text { Kollam } \\
\text { YEAR }\end{array}$ \\
\hline $\begin{array}{c}\text { RE20020b } \\
\text { Devīpratișṭhā } \\
\text { GR / GR }\end{array}$ & 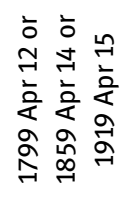 & & & & \\
\hline $\begin{array}{l}\text { OR2348 } \\
\text { Lalitātriśatīnāmāvalī } \\
\text { GR / MP }\end{array}$ & 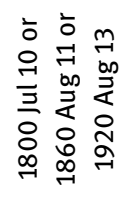 & & 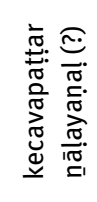 & & \\
\hline $\begin{array}{c}\text { OR2359 } \\
\text { Cakravidhi } \\
\text { GR / GR } \\
\text { (n TA only potțāci) }\end{array}$ & 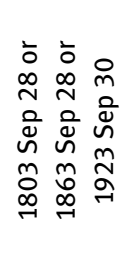 & & & 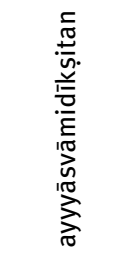 & \\
\hline \multicolumn{6}{|c|}{ COLOPHONS WITH ONLY PLACE NAMES } \\
\hline $\begin{array}{c}\text { RE22704 } \\
\text { Amarakośaḥ } \\
\text { Drāviḍațīkāsahitaḥ } \\
\text { MP / MP }\end{array}$ & & & 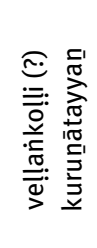 & 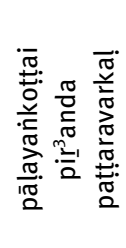 & \\
\hline
\end{tabular}




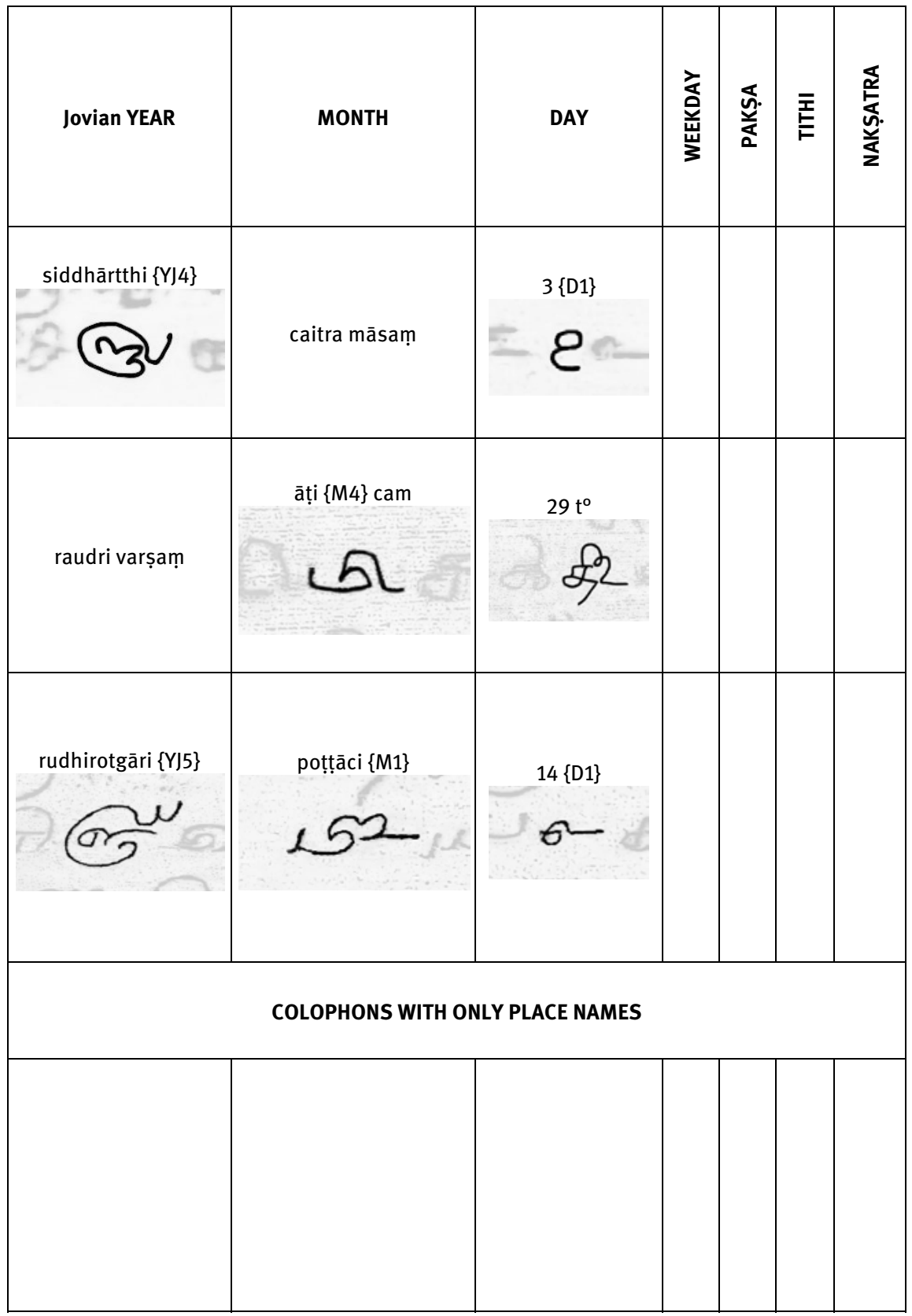




\section{Appendix 2: Corpus}

Note: If not otherwise indicated, the date refers to when the manuscript was completed.

\section{RE05915 - Jayantīpurāmāhātmya (21 July 1827)}

[41v3] hariḥ om śubham astu | śrīvallidevasenāsametaśrīsubrahmanyasvāmi[X]sahāyam | --- $1002\{$ YK2 $\}$ āñi $\{\mathrm{M} 2\} 9$ \{D1\} eluti mukiñcutu ---

Harih om, may there be prosperity. With the support of śrī Subrahmanya along with [his spouses] śrī Vallī and Devasenā, [this manuscript] was fully written [in the] Kollam year 1002, month of Āni, 9th day.

Notes: (1) Varadachari (1986: 186-7) thinks that the manuscript looks much younger than the age indicated by the date in the colophon. (2) According to Varadachari (1986: 186-7), Jayantipura is another name for the town of Tiruccentūr (Tiruchendur/Thiruchendur) in the Tūttukkutị māvațtam (Thoothukudi district). In fact, the Tiruccentūr Cuppiramaṇiyacuvāmi Kōyil (Thiruchendur Murugan Temple), where Murukan is venerated as Subrahmanya (Cuppiramaniya in Tam.), along with his two wives, is there.

\section{RE05920 - Śucīndrasthalamāhātmya (30 or 31 December 1880)}

[89r7] harị̣ oṃ | sahasrādhikașaṭpañcaḥ vikramanā[89r7]masaṃvatsare dhanurmmāse saptadaśa[Ła]divase bhrguvāsare pūrvapakșacaturddaśyām jyeșțhā[na]kșatre divase ejuśākhāddhyāyān [89v1] śrīvatsagotrotbhave satyāṣaḍasūtraḥ [X] cucīndiraṃ nārāyaṇar putran senāpati [X] likhitam | hari om [89v2] śubham astu gurubhyo namaḥ | sthāṇusahāyam

Harih om. [In the Kollam year] 1056, the [Jovian] year called Vikrama, month of Dhanus, the 17th day, a Friday, the 14th [tithi] of the bright fortnight, under the Jyeșțā constellation, on [this] day Senāpati from Cucīndiram, reciter of the Yajurveda, born in the Srīvatsa gotra, [belonging to the tradition] of the Satyāșa $[$ [h] asūtra, son of Nārāyaṇar, wrote [this manuscript]. Harih om. May there be prosperity. Honour to the teachers. With the support of Sthāṇu (i.e. Śiva).

Notes: (1) Divase has been translated as 'on [this] day' since it resembles the Tamil expression inta subhadinattil found in the colophons of many other manuscripts, such as E00003a. (2) The locative form in ${ }^{\circ}$ otbhave seems to be a mistake. (3) The syntax seems to be rather loose, thus the passive verbal form likhitam has been translated as active.

\section{RE08256 - Sakalāgamasarasaṃraha (24 January 1834)}

[162v2] śubham astu śriparvatavarddhanīsametaśrirāmanāthāya namah | ambū̄sahā[yam] [162v3] vijaya $\{\mathrm{YJ} 1\}$ tai $\{\mathrm{M} 1\} 13$ [D2\} śukravāram punarvasunakṣatram subhadinattil 
perivālakṛṣna kurukkal uṭaiya pustakattaip pār $\underline{2}^{2} t$ yenakku yelutik koṇțen ākamam pa[r]vatayyan hastali[162v4] khikhitam [sic!] śubham astu śriambāsahā $y^{\circ}$ dharmmadevataye sahāya $a^{\circ}$

May there be prosperity. Honour to śrī Rāmanātha together with [his spouse] śrī Parvatavardhani. With the support of Ambā. In the Jovian year Vijaya, month of Tai, 13th day, a Friday, under the constellation of Punarvasu, on [this] auspicious day, having seen the book belonging to Perivāla Kṛ̣ṇa Kurukkal, I, Âkamam Parvatayyan, wrote [this manuscript] for myself. May there be prosperity, with the support of śrī Ambā [and] the God of Dharma.

\section{RE10829 - Vātulaśuddha (26 December 1797; change of ownership (?) 9 April 1823)}

[134r5] pimgalasaṃva[134r6]ssara dhanurmmāsa pañcadaśamadinam śubham astu satyajñāni

[Jovian] year Pingala, month of Dhanur, 15th day. May there be prosperity. Satyajñāni.

[134v1] subhānu \{YJ4\} cittirai \{M3\} 8 | śanikkilamaiy 8 āyilliya [one or more syllables missing] [134v2] tra† tiruvaiyāru

Jovian year Subhānu, month of Cittirai, 8th [day], Saturday, 8th [tithi], [constellation of] Āyilliya. Tiruvaiyāru.

Notes: (1) The meaning of the word satyajñani is not immediately clear. Most probably, it indicates the name of the scribe, since it is written by the same hand that copied the text of the whole manuscript. The same name, written by the same hand, is also found in RE10845 (manuscript not studied in this article). At present, it cannot be ascertained whether Satyajñani was also the owner of the two manuscripts. (2) The second date, which was added by a second hand to the verso of the folio and left uninked, could be that of the first owner of the manuscript, or record the change of ownership of the manuscript, in case Satyajñani were the first owner.

\section{RE20020b - Devīpratișțhā (12 April 1799, 14 April 1859, or 15 April 1919)}

[6v3] harị̣ om śubham astu śrigurubhyo namaḥ \| sahāyadāmnisametaśritanunātheśvarasvāmine namaḥ | siddhārtthi \{YJ4\} caitra māsaṃ $3\{$ D1\} ---

Harih om. May there be prosperity. Honour to the teachers. Honour to the image (svamin) of Śritanunātha (i.e. Śiva) together with Sahāyadāmnī. Jovian year Siddhārtthi, month of Caitra, 3rd day.

Note: Śritanunātha and Sahāyadāmnī are the names of the installations of Śiva and his wife as worshipped at the Tirumēnninātar temple of Tirucculi. 


\section{RE22704 - Amarakośah Drāviḍațīāsahitah (no date)}

[79r4] nāmalimgānuśāsana[79r5]ttile prathamakāṇḍaṃ saṃpūrṇaṃm āy mukintatu ॥ śrīrāmacandrāya paramagura[79r6]ve namah || rājagopālasvāmisahāyam \| --- * * * *

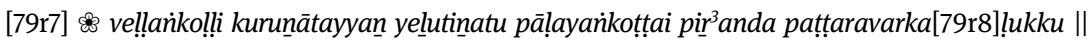
śrīsāṃbasadāśivāya namaḥ $\|---*\|---\mathbb{B}^{3}$

The first chapter of the Nāmalimgānuśāsanam has been fully completed. Honour to the supreme guru śrī Rāmacandra. With the support of Rājagopālasvāmin. Velḷaṅkoḷ̣i (?) Kurunātayyan wrote [this manuscript] for Pațtaravarkaḷ, who was born in Pālayañkoțtai. Honour to śrī Sadāśiva along with Ambā.

Note: It is possible that Vellankolli corresponds to a town halfway between the cities of Kollam and Tiruvanantapuram (Thiruvananthapuram/Trivandrum), which are both found in presentday Kēraḷam (Kerala) (see website /9/).

\section{RE37121 - Amarakośạ̣ (with Tamil meaning) (4 January 1797, 5 January 1857, or 7 January 1917)}

[27v5] ity amarakośe prathamakāṇḍas samāptaḥ | --- hariḥ om | śubham astu avighnam astu

[27v6] bind[u]durllipivisargavīdhikāpañntibhedapadabhedadūṣaṇaṃ|

hastavegajam abuddhipūrvakaṃ kṣantum arhatha samīkșya satjanāh |

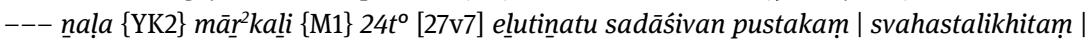
asmatgurucaraṇāravindābhyo namah $\mid---$ om

The first section of the Amarakośa is completed. Harih om. May there be prosperity. May there be no obstacle.

O good people, once you have investigated [this manuscript], you may forgive [any] unintentional mistake[s] concerning nasal signs, bad writing, signs of aspiration at the end of words, a row, omission of a line (parikti-bheda) or word, which are born from a hasty hand.

Sadāśivan wrote [this] book with his own hand in the Jovian year Naḷa, month of Mārkali, 24th day. Honour to the lotus like feet of our guru. Om.

Notes: (1) The stanza is in rathoddhatā metre. (2) ${ }^{\circ}$ vidhik ${ }^{\circ}$ should be read as ${ }^{\circ} v \bar{t} t h i k \bar{a}^{\circ}$ ('row'), and ${ }^{\circ}$ parnnti ${ }^{\circ}$ should be read as ${ }^{\circ}$ parikti ('line'). It is not clear to what exactly the former refers, since the latter seems to indicate the same phenomenon, i.e. the 'omission of a line' or 'aplography'. (3) Naḷ should be read as Nala, and $M \bar{a} \underline{r}^{2} k a \underline{l} i$ as Mārkali. (4) Note that the name of the Jovian year is followed by a symbol for the Kollam year. 


\section{RE45807 - Amarakośaḥ Drāvị̣ārthasahitạ̣ (14 September 1796, 16 September 1856, or 17 September 1916)}

[36r1] śubham astu --- || kumāragurave namaḥ --- [36r2] icalimațai kopālakṛṣnañ elutinnatu naḷa $\{\mathrm{YJ} 2\}$ piratțaci $\{\mathrm{M} 1\} 3\{\mathrm{D} 2\}$ amaram - prathamakānțam - eḷti mukintatu ---

May there be prosperity. Honour to Kumāraguru. Kopālakṛṣnan from Icalimațai wrote in the Jovian year Nala, month of Pirațaci, 2nd day. He finished writing the first chapter of the Amara $[k o s ́ a]$.

\section{EO0001 - Tiruvāymoḷi Nālām Pattu İtu Vyākhyānam (30 June 1829) (the date 4 May 1829 is also recorded)}

[GL1r1] śrīmate rāmānujāya namaḥ tiruvāymoli nāāā $\mid m /$ pattu yīṭu vyākhyānam jīyar tiruvațikale caraṇam --- tirukkurukaip perumāl ---

Honour to śrīmat Rāmānuja, Tiruvāymoli Nālām Pattu Ị̇tu Vyākhyānam, the holy feet of Jīyar are the refuge. Tirukkurukai Perumāḷ.

[GL2r1] śrīmate rāmānujāya namaḥ tiruvāymoli nālām pattu yīṭu vyākhyānam jīyar tiruvațikaḷe śaraṇam tirukkurukaipperumāl dāsan ---

Honour to śrīmat Rāmānuja, Tiruvāymoli Nālām Pattu Ị̇u Vyākhyānam, the holy feet of Jīyar are the refuge. Devotee of Tirukkurukai Perumāḷ.

[GL3r1] śrī[ma] d varavaramunaye namaḥ tiruvāymoli nālām pattu yīṭu vyākhyānam --- jūyar tiruvațikale carạ̣am ---

Honour to śrīmat Varavaramuni, Tiruvāymoli Nālām Pattu Ị̇u Vyākhyānam, the holy feet of Jìnar are the refuge.

[GL3v1] gopālapillaai kuțta rāmānu[ja]nūntantāti urai [GL3v2] jñānasāram prameyasāra vyākhyānam periyatirumuți[GL3v3]yațaivu dinacari vāli tirunāmañkal yivaḷavu munnamum kuțutt ${ }^{\circ}$ kutu [GL3v4] cittira \{M2\} 24 \{D1\} 1004 \{YK3\} kuțutt ${ }^{\circ}$ kutu

The Rāmānu[ja]nūntantāti Urai, the Jñānasāram, the Prameyasāravyākhyānam, the Periyatirumuțiyațaivu were given by Gopālapillai. Having praised the holy names every day, so much [i.e. so many manuscripts] is already given. It is given on the month of Cittira, 24th day, Kollam year 1004.

[140r5] ālvār tiruvațikaḷe caraṇam | emperumānār tiruvațikale caraṇam --- maṇavāla māmunikal tiruvațikaḷe caranam --- śrīmad varavaramunaye namaḥ [140r6] rāmānujadāsan caramāvadhidāsan dāsānudāsan tirukkurukaip perumāl ācāryyan tiruvațikale tañcam jīyar tiruvațikale tañcam --- [140r7] 1004 \{YK3\} āñi \{M2\} 19 \{D1\} samāptam --- 
The holy feet of the Ālvār are the refuge. The holy feet of Emperumāñār (= Rāmānuja) are the refuge. The holy feet of Manavāla, the great sage, are the refuge. Honour to śrimmat Varavaramuni. The holy feet of master Tirukkurukai Perumāl, devotee of Rāmānuja, last (caramāvadhi) of the servants, servant of servants, are the refuge. The holy feet of Jiyar are the refuge. [The manuscript] was finished in the Kollam year 1004, month of Āni, 19th day.

Notes: (1) Since this colophon presents a list of many śrīvaiṣnava teachers, such as Emperumān̄ār/Rāmānuja, Maṇavāla, etc., one cannot exclude the possibility that Tirukkurukai Perumāl corresponds to Tirukkurukaippirānnpiḷān̄ here, a śrīvaiṣnava master of the twelfth century, who was a pupil of Rāmānuja (Venkatachari 1978: 61-64). Alternatively, the expression tirukkurukaipperumāl dāsan could be interpreted as 'Tirukkurukai Perumāl, devotee [of Rāmānuja]' in the light of E00006 [GL1r2] and [52r7]. (2) The colophon found in [GL3] presents a rather colloquial style. In particular, one should note the form kuțta for kuțutta, and the expression kututt ${ }^{\circ} k u t u$, which seems to mark a contracted form of the standard kuțutt' irukkiratu with a symbol for abbreviation (Vijayavenugopal personal communication). If its interpretation is correct, this colophon does not pertain to the production of EO0001, but refers to the date of donation of three other manuscripts.

\section{E00002a - Tulākāverīmāhātmyam (Āgneyapurāṇa) (22 March 1819)}

[106v4] āgneyapurāṇe kāverīmāhātmya samāptam | [106v5] hariḥ om --- kāveryyai namah --- | śrīmate rāmānujāya namaḥ --- śrīmahāpūrṇagurave namaḥ | --- śrīvaikuṇṭanāthasvāmine namah --- [106v6] 994 \{YK2\} bahudhānya \nāma/ saṃvatsare uttarāyaṇe phālgunamāse ekādaśadivase induvāsare ekādaśyām śravaṇanakṣatre narasiṃhāryyapautrena [106v7] śrīraṃgācāryyasūnunā | coranāthe \nal likhit $[\mathrm{X}] \backslash \bar{a} \mid$ kāverīmahimā $+\backslash+[?]$ tā $+/[\mathrm{XXX}] \mid---\sim$ śrīdhanvinū[X] tanapurīgurave namah | śrīramgavallyai namah--- |

The Kāverīmāhātmya in the Āgneyapurāna is completed. Harih om. Honour to the Kāverī. Honour to śrīmat Rāmānuja. Honour to the guru śrī Mahāpūrṇa. Honour to śrī Vaikuṇțanāthasvāmin. In the Kollam year 994, Jovian year called Bahudhānya, in the second fortnight, month of Phālguna, 11th day, on Monday, 11th [tithi], under the Śravana constellation, Coranātha grandson of Narasiṃhāyya and son of Śrīramgācāryya wrote the Kāverīmahimā (?). Honour to the guru of Śrīdhanvinūtanapurī (?). Honour to Śrīramgavallī.

Notes: (1) The scribe, Coranātha, is the son of Srīraṃācāryya and grandson of Narasiṃhā[ca]ryya. Veṃkațācāryyar (the scribe of EO0002, E00007 and E00069) is also the son of a man called Śrīramgācāryya. Since the two scribes were active in the same period, they may have been brothers. Unfortunately, we cannot confirm this hypothesis since we do not (yet) know the name of Veṃkațācāryyar's grandfather. (2) The form ${ }^{\circ} \bar{a} r y y a^{\circ}$ could be a contraction of ${ }^{\circ} \bar{a} c \bar{r} r y y a^{\circ}$. (3) The identification of both the guru of Śrīdhanvinūtanapurī (?) and Śrīramgavallī has not yet been made. 
E00003a,b,c,d

\section{E00003a - Triṃśatpraśnottara (17 August 1845)}

[68v3] harih om - śubham astu - --- || śrīmatbhyo parāṃkuśaparakālayativarādibhyo namah - śrīmahāpūrṇagurave namaḥ - --- || [68v4] 1021 \{YK1\} viśvāvasuvarșam āvaṇi māsaṃ 3 \{D1\} nāttikkelamai paurṇamāvāsai - avuțta nakșattiram - yinta śubhadinattil [68v5] triṃśatpraśnottara[khaṇdana] \ṃ eluti/ mukintatu - periyanampi veñkațācāriyar svahastalikihitam - muluvatum - periyanampikal tiruvațikale carạ̣ ${ }^{\circ}---$

Harih om. May there be prosperity. Honour to śrīmat Parāṃkuśa, Parakāla and Yativara. Honour to guru śrī Mahāpūrṇa. In the Kollam year 1021, Jovian year Viśvāvasu, month of Āvani, 3rd day, on Sunday, under the full moon, under the constellation of Avutța, on this auspicious day, the Triṃśatpraśnottara was fully written. Periyanampi Veñkațācāriyar completed [it], writing with his own hand. The holy feet of Periyanampikal are the refuge.

\section{E00003b - Triṃśatpraśnottarakhạ̣̣̣ana (25 September 1845)}

[129v6] śrīmate rājāya namaḥ - śrīmahāpūrṇagurave namaḥ - - harị̣ om śubham astu - --- || $1021\{\mathrm{YK} 2\} \quad$ ।+ viśvāvasuvarșaṃ/ piratțāci $\{\mathrm{M} 2\} \quad 11$ [D1\} vyālakkela[129v7]mai ।+ krṣnnapakșattu/ daśami tithi punarvasu nakșattiram inta śubhadinattil trimsśatpraśnottarakhaṇdanaṃ eluti mukiñcatu - periyanampi venkkațācāriyar svahastalikihitam ----

Honour to śrīmat Rā[mānu]ja. Honour to guru śrī Mahāpūrṇa. Hariḥ om, may there be prosperity. In the Kollam year 1021, Jovian year Viśvāvasu, month of Piratțāci, 11th day, on Thursday, 10th [tithi] of the dark fortnight, under the constellation of Punarvasu, on this auspicious day, the Trimśatpraśnottarakhaṇana was fully written by Periyanampi Ven̉kațācāriyar with his own hand.

\section{E00003c - İtupāṭu of Jīyar (2 October 1845)}

[18(148)v3] - --- ||| harih om - śubham astu - - --- || [18(148)v4] yemperumān̄ār tiruvațikaḷe caraṇam - maṇavāla māmuñika! tiruvațikaḷe caraṇam - --- - śrīmahāpūrṇa gurave namaḥ - --- || [18(148)v5] 1021 \{YK1\} viśvāvasu nāma saṃvatsaraṃ kanyāmāsam

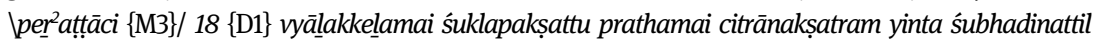
[18(148)v6] jīyar ițupāṭu - eluti mukintatu - --- - periyanampi veñkițācāriyar svahastalikihitam - muḷvatum ---- || *----- \|

Harih om. May there be prosperity. The holy feet of Emperumān̄ār (= Rāmānuja) are the refuge. The holy feet of the great sage Manavāla are the refuge. Honour to guru śri Mahāpūrṇa. In the Kollam year 1021, the Jovian year called Viśvāvasu, month of Kanyā 
[alias] Peratțāci, 18th day, on Thursday, 1st [tithi] of the bright fortnight, under the constellation of Citrā, on this auspicious day, the Ițupațu of Jìyar was fully written. Periyanampi Veṅkațācāriyar completed [it], writing with his own hand.

Note: Muḷvatum should be read as muluvatum (see E00003d [30(160)r6]).

\section{E00003d - Svarūpavijñānavikāsadarppaṇam (or Ị̇̂pāțu) of Vedāntācaryyar (3 October 1845)}

[30(160)r4] - --- || iti vedāntācaryyasvarūpavijñā[X]\na/vikāsada[X]rppaṇam sampūūṇam || --- [30(160)r5] 1021 \{YK1\} viśvāvasu saṃvatsaram poțțāci $\{\mathrm{M} 2\} 19$ \{D1\} vellikkelamai śuklapakșattu dvitiyai - svātīnakșatram - yinta śubha[30(160)r6]dinattil vedāntācaryyar ițupāțu e \ֵu/ti mukiñcu \nta//tu - --- || periyanampi veñkațācāriyar svahastalikihitam muluvatum ---- \|

The Svarūpavijñānavikāsadarppaṇam of Vedāntācaryya is completed. In the Kollam year 1021, Jovian year Viśvāvasu, month of Potțāci, 19th day, on Friday, 2nd [tithi] of the bright fortnight, under the constellation of Svātī, on this auspicious day, the İtupātu of Vedāntācaryyar was fully written. Periyanampi Veṅkațācāriyar completed [it], writing with his own hand.

Note: The word mukintatu (see, for instance, E00003c [18(148)v6]) can be colloquially rendered as mukiñcatu or mukiñcutu (see E00004 [36v8], for example). Here, it seems that the scribe accounted for both possibilities by writing mukiñcu $\backslash n t a / t u$.

\section{E00004 - Tirumālai Pratipatavurai (29 April 1862)}

(Fig.1) [36v7] || tonttațarțippoțiy ālvār tiruvațiakale caranam || --- || hariḥ om śubham astu || [36v8] 1037 \{YK2\} dundubhi nāma varșam cittirai \{M2\} 18 \{D1\} utaiyattil elu \ti/ mukiñcutu \| periyanampiyal tiruvațika!̣ caraṇam || śrīmahāpūrṇagurave namaḥ ---

The holy feet of the ālvār Toṇtațarțippoți are the refuge. Harih om, may there be prosperity. In the Kollam year 1037, Jovian year Dundubhi, month of Cittirai, 18th day, at dawn, [this manuscript] was fully written. The holy feet of Periyanampiyal are the refuge. Honour to the guru śrī Mahāpūrṇa.

Note: The scribe of this manuscript is most probably that of E00003.

\section{E00006 - Amalạ̣ātipirān Vyākhyāṇam (from 26 August to 7 September 1830; entrustment of a copy based on this manuscript on 26 November 1830)}

[GL1r1] śrīmate rāmānujāya namaḥ amalan̄ātipirānn vyākhyānam --- jīyar tiruvațika!̣e caraṇam --- [GL1r2] rāmānuja dāsan tirukkurukaip perumāl śrīkośam --- śrīmad vara- 
varamunaye namah [GL1r3] itar ${ }^{2} k u$ mel prati ālvārtirunakari criperiyanampi criśrīkośam

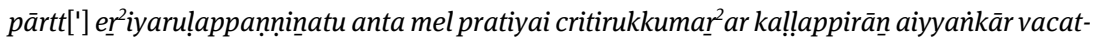
til [GL1r4] $1006\{\mathrm{YK} 3\} k \bar{a} \underline{r}^{2} t^{\circ}\{\mathrm{M} 2\} 13$ [D1\} nelveliyil kkoțuttuvițten ---

Honour to śrīmat Rāmānuja, Amalañātipirān Vy Vyākhyānam. The holy feet of Jīyar are the refuge. The book (śrīkośam) [of] Tirukkurukaipperumāl devotee (dāsan) of Rāmānuja. Honour to śrīmad Varavaramuni. Having Ālvārtirunakari Criperiyanampi seen the book (criśrīkośam), its copy was produced (eriyarulappannininatu); I gave that copy into the custody ( $v a-$ cam) of Critirukkumararar Kaḷlappirān Aiyyañkār in [Tiru]nelveli in the Kollam year 1006, month of Kārtt[tikai], 13th day.

[GL3v1] 1006 \{YK3\} $\bar{a} \backslash v a / n ̣ i$ \{M2\} 12 \{D1\} guruvāram a[XX] \nuṣam/ nakșatram [GL3v2] ārampam \†li†/ āvaṇi $\{\mathrm{M} 2\} 24\{\mathrm{D} 1\}$ utaiyam samāptah

Beginning in the Kollam year 1006, month of Āvani, 12th day, Thursday, under the constellation of Anuṣam; [the manuscript] was finished at dawn on the 24th day.

(Fig.2) [52r6] harih om --- alakiyamaṇavālapperumālnayināàr tiruvațikaḷe caraṇam --- ramyajāmātrmunaye namaḥ --- [52r7] tirukkurukaip perumāl dāsan śrīkośam ācāryyan tiruvațikaḷe tañcam---1006 \{YK3\} āvaṇi \{M2\} 12 \{D1\} ärampañ ceytu 24 \{D1\} utaiyam samāptah

Harih om. The holy feet of Alakiyamaṇavālapperumālnayināa are the refuge. Honour to the sage Ramyajāmātṛ. The book of Tirukkurukai Perumāl, devotee. The holy feet of the teacher are the refuge. Kollam year 1006, month of Âvani; [the manuscript] was begun on the 12th day, and finished at dawn on the 24 th day.

Notes: (1) The term śrikośam is translated as 'manuscript/book' (see Glossary of Historical Tamil Vaishnava Prose 2001 and E00583a). (2) Prati ('copy') is the Sanskritised spelling of the Tamil pirati. (3) Pārtt['] (from pārttu, absolutive form of the verb pār-ttal, 'to see'), which literally means 'having seen', could mean 'having checked' or 'having proofread' here. (4) Vacattil (locative form of vacam) could mean either 'in the custody' or 'in the possession'. (5) The syllable $c r i{ }^{\circ}$ in both criperiyanampi and criśrikośam is just a tentative reading of the character found in the manuscript. It is understood as a Tamil version of the Sanskrit śrī here.

\section{E00007a,b}

\section{E00007a - Candrāvaloka (10 August 1827)}

[11v6] --- candrāvalokas samāptaḥ | --- harị̣ om śubham astu [11v7] mahāpūrṇaśrīraṃgācāryyadāsaveṃkațācāryyaḥ svakīyakaravegena samāptavān | --- 1002 \{YK2\} āṭi \{M3\} $27---\sim$ * --- . . . ---- . . . 
The Candrāvaloka has been completed. Hariḥ om, may there be prosperity. Veṃkațācāryya son of Mahāpūrṇa Śrīramgācāryya completed [it] by the swiftness of his own hand. Kollam year 1002, month of Āṭi, 27th [day].

\section{E00007b - Kuvalayānanda (21 November 1839)}

[119v1] 1015 \{YK2\} kā $\underline{r}^{2} t$ tikai $\{\mathrm{M} 2\} 7$ [D1\}

Kollam year 1015, month of Kārttikai, 7th day.

Note: This colophon was inserted on the verso of the last folio in a different hand from the one that wrote the text contained in the manuscript. Possibly, it was written by the same scribe of E00003 and EO0069, namely Veṃkațācāryyar.

\section{E00009b - Śrīgunaratnakośavyākhyā (or Lakșmīsatgunamāṇikkakośavyākhyā)}

\section{(23 July 1824)}

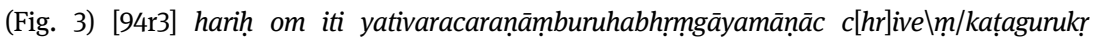
[93r4]pālabdhaśrībhāșyānvayena śrībhāṣyanārāyaṇaguruṇā vira[94r5]citeșu śrīgunaratnakośavyākhyā samāptā| --- harị̣ om śubham astu [94r6]

tāruṇābde gate bhānau kațakaṃ daśame [']hani |

dvādaśyām mṛaśsīrșākhyatārake [94r7] bhṛuvāsare|

lakṣmīsatgunamāṇikkakośavyākhyā vilekhitā |

veṃka[94v8]țāryyābhidhānena śrīramgagurusūnunā |

--- mahāpūrṇagurave namah ---

[94v1] abde tārunanāmake bhrgudine [']py āṣāḍhamāse tithau

dvādaśyām mrrgaśîrșatāra[94v2]sahite pakșe valakșetare |

śrīraṃgāryyajaveṃkațāryyagu[X] ruṇā pūrṇāryyavaṃ[98v3]śotbhave

nādya śrīgunaratnakośaparamavyākhyeyam ālikhyate |--- - \$

(Fig. 4) [94v4] 1000 [1] \{YK1\} tāruna \{YJ2\} āṭi \{M3\} 10 \{D1\} dvādaśi tithi vellikelamai mrgaśîrșanakșattiram [94v5] inta śubhadinattil periyanvika! tirumālikai śrīreṃgācāryyar dāsan veṃka[94v6]țācāryyar svahastena eluti mu \ki/ttān̄ śrīguṇa[X]ratnakośavyākhyānam muluvatum |--- |||

Hariḥ om. The Śrīgunaratnakośavyākhyā has been completed, which is among the compositions (viraciteșu) of guru Śrībhāṣyanārāyaṇa of the Śrībhāṣya lineage, for which he obtained the grace of śrī Veṃkațaguru by approaching (ayamānāt) the lotus-like feet of Yativara (= Rāmānuja) [as] a bee. Harih om, may there be prosperity.

When the sun (bhānu) entered the Tāruna year, in [the month of] Ka[rka]țaka, on the 10th day,

on the 12th [tithi], under the constellation called Mrgaśīrșa, on Friday,

the Lakșmīsatgunamānikkakośavyākhyā was written

by the one called Veṃkațāyya, son of the guru Śrīraṃga.

Honour to the guru Mahāpūrṇa. 
In the year called Tāruṇa, on Friday, also in the [lunar] month of Āṣāḍha, on the 12th tithi, under the constellation of Mrgaśīrșa, in the other fortnight than the bright one (pakșe valakșa-itare), today, this Śrīguṇaratnakośaparamavyākhyā has been written by the guru Veṃkațāryya, son of Śrīramgāryya, born in the Pūrṇāryya lineage. In the Kollam year 1000, Jovian year Tāruṇa, month of Āṭi, 10th day, 12th tithi, Friday, under the constellation of Mrgasīisṣa, on this auspicious day, Veṃkațācaryyar, son of Śrīremgācāryyar, the vaiṣnava teacher (periyanvikal) of respectable family (tiru-mālikai), has fully written (elluti mukittān [...] muluvatum) the Śriguṇaratnakośavyākhyāna with his own hand.

Notes: (1) The amending of ayamānācciveṃkațaguru ${ }^{\circ}$ to ayamānāc c $[h r] i v e m ̣ k a t ̦ a g u r u^{\circ}$ (i.e. ayamānāt śriveṃkațaguru ${ }^{\circ}$ ) is somewhat tentative. (2) The two stanzas are in anușțubh and sāardūlavikrīilita metre respectively.

\section{E00069 - Așțādhyāyī (or Vvyākaraṇasūtram) (from 5 November 1824 to 15 No- vember 1829)}

[GL1r1] hariḥ om śubham astu - avighnam astu | [GL1r2] vyākaraṇasūtram așțāddhyāyī |--$\sim$ || [GL1r3] (uninked and effaced line)

Harị om, may there be prosperity. May there be no obstacle. Vvyākaraṇasūtram Așțāddhyāyī.

(Fig. 5) [GL2r1 col1] asmin dāruṇanāmābde tulām prāpte divākare | [GL2r2 col1] śuklapakṣe caturddaśyām aśvinyām śukravāsare |

[GL2r3 col1] śrīraṃgarājadāsa sva||raṃgarājātmaja svena//kareṇa veṃkațāryyakaḥ|

[GL2r4 col1] premayārabdhavān așțāddhyāyīsūtraṃ vilekhitum |

In this [Jovian] year named Dāruṇa, when the sun has entered the [month of] Tulā, in the bright fortnight, on the 14th [tithi], under the [constellation] of Aśvinī, on Friday, the pitiful Veṃkațāryya, son of Śrīrangarāja, with his own hand, began to write the Aștāadhyāyissūtra, out of affection [for that work] (?).

Notes: (1) As suggested by Varadadesikan (personal communication), the suffix $-k a$ in veṃkațāryyakah could indicate humbleness. In fact, rule 5.3 .78 of the Aștāadhyāyi prescribes [anukampāyāṃ (5.3.77)] bahvaco manușyanāmnaș țhaj vā ('Optionally, the suffix -ka (țhac) [can be used] after a polysyllabic personal name [to express compassion]') (see, for instance, Katre 1987: 603). (2) Possibly, premayā is an ungrammatical variant of premnā, the instrumental of preman ('affection'). (3) The two stanzas are in anuștubh metre. The interlinear insertion |ramgarājātmaja svena/ seems to be a later attempt by the scribe to compose a verse in which the caesura does not fall in the middle of a word or a compound, as is customary in Sanskrit metrics. In fact, ramgarājātmaja svena | kareṇa veṃkațāryyakah would be considered to be a 
better verse than śrīraṃgarājadāsa sva|kareṇa veṃkațāryyakah. The same solution is not attempted in the following verse, where the caesura splits the compound as follows: așțālddhyāyīsūtram.

[GL2r5] 1000 \{YK1\} tāruṇa \{YJ1\} ar²paci \{M3\} 22 \{D1\} vellikkelamai śuklapakṣattil caturddaśi aśvatīnakșattiram yinta [GL2r6] śubhadinattil periyanvi śrīraṃgācāriyar dāsan veṃkațācāryyar vyākaraṇasūtram așțāddhyāyīm [GL2r7] svahastena eluta ā $\backslash \bar{a} / /$ raṃbhiccān

In the Kollam year 1000, Jovian year Tāruna, month of Arpaci, 22nd day, on Friday, in the bright fortnight, 14th [tithi], under the constellation of Aśvatī (= Aśvinī), on this auspicious day, Veṃkațācāryya, son of the vaiṣnava teacher (periyanvi) Raṃgācāryya, began to write the Vyākaranasūtram Așțāddhyāyi with his own hand.

Notes: (1) In the manuscript, the initial $\bar{a}^{\mathrm{o}}$ in $\bar{a}$ rambhiccān $\underline{n}$ is written twice, above in Tamil and below in Grantha. (2) Periyanvi is an abbreviated form of periyanampi; see below [63v8].

(Fig. 6) [63v5] harị̣ om śubham astu - addhyāyo [']pi samāptạ̣ | śāstram api parisamāptaḥ --- [63v6] namah pāninikātyāyanipatañjalibhyah |--- 1005 \{YK1\} virodhivarșam kārttikai \{M3\} 2 [D1\} nāttikkela[63v7]mai kṛșnapakșat ${ }^{\circ}$ pañcami punarvasunakșatram inta śubhadinat ${ }^{\circ}$ vyākaraṇasūtram eluti mukiñcutu muluvatum --- [63v8] idaṃ vyākaraṇasūtram periyanampi śrīraṃgācāryyar dāsan veṃkațācāryyar svahastalikhitan nikhilam ---

[63v9] śrīpūrṇaveṃkațāryyeṇa śrīraṃgagurusūnunā |

svakīyena kareṇāșțāddhyāyīsūtraṃ vilekhitam |--- ||||

Harih om, may there be prosperity. [This] section is also completed. And the treatise is also fully completed. Honour to Pāninini, Kātyāyana and Patañjali. In the Kollam year 1005, Jovian year Virodhi, month of Kārttikai, 2nd day, on Sunday, in the dark fortnight, on the 5th [tithi], under the constellation of Punarvasu, on this auspicious day, the Vyākaranasūtram has been fully written (eluti mukiñcatu muluvatum). This Vyākaraṇasütram has been entirely written with his own hand by Veṃkațācāryyar, son of the vaiṣnava teacher (periyanampi) Śrīraṃācāryyar.

With his own hand the Așțāddhyāyīsūtra was written, by Śrīpūrṇaveṃkațāryya, son of Śrīraṃgaguru.

Notes: (1) The final -ttil is written in this manuscript in four different ways: -ttil (as in ḳ̣ṣnapakșattil and śubhadinattil [63v7]), -tti-l (as in śuklapakșattil [GL2r5]), and -t-ti-l (as in śubhadinattil [GL2r6]). (2) The stanza is in anușțubh metre.

\section{E00583a,b}

Preliminary notes: (1) Both colophons present some rather obscure passages. For instance, the expressions tiruvāymolipillaiv eñru mālaipilllaikumārar (EO0853a [GL1v7-8]) and tiruvāymoliv enru mālaipillai (EO0583b [95v10-11]), the latter apparently a reduced version of the former, are particularly difficult to account for. Furthermore, despite the fact that, if our interpretation is correct, EO0583a and EO0583b were written by two different scribes, the hand of both manu- 
scripts looks very similar. (2) In his cataloguing sheets for this manuscript, Varadadesikan described only what we call EO0583b here, labelling it Ācāryabhakti, which seems to be the name of the literary genre rather than the text itself. Here we tentatively propose two different titles on the basis of our reading of the colophons. In fact, neither of them seems to be recorded in the secondary literature.

\section{E00583a - Tirunakarippi!̣ai Rahasyam (?) (4 October 1738)}

(Fig. 7) [GL1v4] --- śrīmate rāmānujāyaya namah |--- | [GL1v5] 914 \{YK2\} kālayukti \{YJ3\} ar²ppaci \{M3\} 2 \{D1\} budhanniki[GL1v6]l_amaiyum pūrvapakșatritikaiyum viśākhānakșatra-

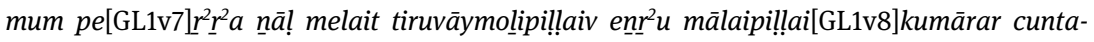
rarācapiḷaikku eñ $\underline{r}^{2} u t$ tirunakarippiḷai raha[GL1v9]syam śrīnivāsarāmānujadāsan svahastattināle eluti ni[GL1v10]r² avettinān̄ cuntararācapiḷai śrīkośam - ---

Honour to śrimat Rāmānuja. On the day on which the Kollam year 914, the Jovian year Kālayukti, the month of Arppaci, the 2nd day, Thursday, the 3rd [tithi] of the bright fortnight, and the constellation of Viśākhā all fall (perra-ñāl-melai), Śrīnivāsarāmānujadāsan finished writing the Tirunakarippillai Rahasyam (?) with his own hand exclusively (enrru) for Mālaipiḷ!aikumārar Cuntararācapiḷ!ai, tiruvāymolipiḷaiv eñru (?). The book (śrīkośam) of Cuntararācapiḷ̣ai.

Notes: (1) Although marked as GL here, this is probably the only surviving folio of a manuscript with no page numbers. Presumably, the manuscript was lost or destroyed. (2) Tiritikai (also spelt tiritiyai) is the Tamil name of the 3rd tithi (see Skt. tritìy $\overline{\text { ) }}$.

\section{E00583b: Sārārttharatnamālai (?) (21 October 1738)}

(Fig. 8) [95v8] --- hariḥ om śubham astu - --- [95v9] 914 \{YK2\} kālayukti \{YJ3\} ar²ppaci \{M3\} 19 \{D1\} aparapakșapañcamiyum sthiravāsa[95v10]ramum ārdrānnakșatramum petta

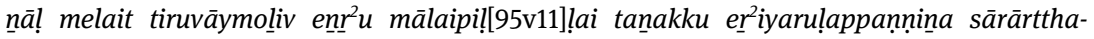
ratnamālai sampūrṇam āka triver ${ }^{2} u[95 \mathrm{v} 12]$ ttu† - śrišailanāthagurave namah - piḷai tiruvațikale caraṇam

Harih om, may there be prosperity. On the day on which the Kollam year 914, the Jovian year Kālayukti, the month of Arppaci, the 19th day, the 5th [tithi] of the dark fortnight, Saturday, and the constellation of Ārdrā all fall (petta-nāl -melai), having fully completed the Sārārttharatnamālai, which Mālaipilḷai, tiruvāymoliv eñru (?), copied for himself (?). Honour to the guru śrī Śailanātha. The holy feet of Piḷlai are the refuge.

Notes: (1) Tiruvațikale should be read as tiruvațikale. (2) Riveruttu could be read as niraiverurru, which would resemble an irregular absolutive form of the root niraiveru ('to complete'). (3) Both Śailanātha and Pill!ai could be tentatively understood as appellatives of Tiruvāymolipill!ai, a śrīvaișnava master of the fourteenth century, also known as Śaileśa (see Śailanātha in [95v12]) (Venkatachari 1978: 86-87). 


\section{UVSL107 - Akanāñūru (November 1726)}

[GL?4] ven tāmaraiyāḷ vilaniku maṇi nūpurañ cūl tạn țāmaraiye caraṇa[m] --- ālvār tiruvațikale caraṇam --- --- [GL?5] 902 \{YK2(?)\} kārttikai māta mutal reñkanātañ eluti

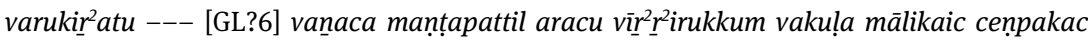
cațakopak kārimā $\underline{r}^{2}$ avar tan $\underline{r}^{2}$ iruvațikaḷ caraṇam --- pațcirācak kațavul pātāravinta keti

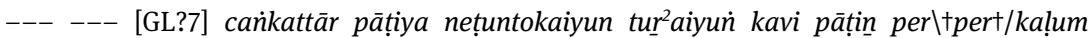
elutiyirukkutu --- makilmā $\underline{r}^{2}$ avar tan malar ațiye tañcam --- śubham astu śrī rāma jayam --- keruțāya namah --- ---

The cool lotus surrounding the shining jewel anklet of the female one on the white lotus is the refuge. The holy feet of the Âlvār are the refuge. [This manuscript] is being written by Renikanātan and was begun in the month of Kārttikai in the Kollam year 902. The holy feet of Cațakōpan Kārimāravar (= Nāmmalvār) with campakam for a garland [along with] vakulam, who sits in distinction as king of the lotus temple hall are the refuge. The lotuslike feet of the god [seated] on the king of birds are the refuge. The Netuntokai ('Long Collection') sung by those of the academy and the miniature commentaries and the names of the songs' poets have been written. The flower feet of joyful Māravar are the refuge. May there be prosperity. Victory to śrī Rāma. Honour to Garuḍa.

Note: The translation is a slightly modified version of the one in Wilden 2014: 129.

\section{UVSL511 - Kalittokai (February 1675)}

[last folio damaged, v2] $850\{\mathrm{YJ} 4\}$ māci \{M3\} [part of the folio missing] [v3] tiruvarūril irukkum ceñkamala por ${ }^{2}$ patam mar $\underline{2}^{2}$ aiñāna paṇtarattin puttiran civakurunātan el eluttu [v4 contains 12 illegible characters]

Kollam year 850, month of Māci, the script of Civakurunātan, son of Ceñkamala Porpatam Maraiñāña Paṇțaram, who is in Tiruvarūr.

Notes: (1) The UVSL catalogue (Ramanuja Aiyangar 1956: 249-250) interprets the day as the 29th. It is possible that the folio was in better condition at the time the catalogue was prepared. (2) Tiruvarūr is more often spelled Tiruvārūr (Thiruvarur). (3) The translation is a slightly modified version of the one given in Wilden 2014: 132.

\section{UVSL1080a, $c^{58}$}

[GL2r1 col2] ețtaiyapuram [GL2r2 col2] araṇamañai [GL2r3 col2] jēyam

The palace of Eț̣aiyapuram. Victory.

58 In connection with the interpretation of the colophons of UVSL1080a,c we would like to acknowledge the collaboration of Jonas Buchholz. 


\section{UVSL1080a - Cịupañcamūlam (29 April 1873)}

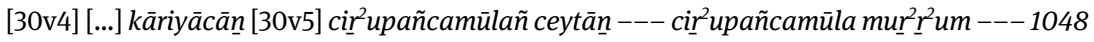
\{YK2\} śrīmuka \{YJ2\} cittirai \{M2\} 18 \{D1\} [30v6] tirunelveliyil eluti muṭittatu - civacuyampirakāca munnnir ${ }^{2} k a[30 \mathrm{v} 7]$ ta kumārețțu cakkatēvi munnnir ${ }^{2} k a$ vēnțiyatu

[...] Kāriyācān composed the Cịupañcamūlam. The Cịrupañcamūlam is finished. In the Kollam year 1048, Jovian year Śrimuka, month of Cittirai, 18th day, it was fully written in Tirunelvēli. May Civacuyampirakāca stand in front [of me]. Cakkatēvi [worshipped by] Ta Kumārețtu should stand in front [of me] (?).

\section{UVSL1080c - Ācārakkōvai (2 May 1873)}

[25r3] ācārakkōvaiy urai murrrirrru--- [25r4] $k[\bar{a}]$ ntimati nellaiyappar munnnirka --- 48 \{YK2\} śrīmuka \{YJ2\} cittirai \{M2\} 21 [D1\}--- makārācā avarka[25r5]luțaiya ūliyam[X] mu - kumārețtu tirunelvēliyil elutiyatu --- nañrāka tēvituṇaic [25r6] ceyya vēṇțiyatu --- tavacittampirān ririruvaruḷe caraṇam ---

The commentary on the Ācārakkōvai is completed. May I stand in front of Nellaiyappar (= Śiva) [together with] Kāntimati. In the Kollam year [10]48, Jovian year Śrimuka, month of Cittirai, 21st day, in service of the great king, Mu (?) Kumārețu wrote in Tirunelvēli. May there be prosperity, [he] desired to serve the Goddess. The holy grace of Tavaci Tampirān is [our] refuge.

Notes: (1) The town of Etțaiyapuram (Ettayapuram) used to be in Tirunelvēli māvatțam (Tirunelveli district); today it is part of Tūttukkuṭi māvatțam (Thoothukudi district). (2) The colophons of UVSL1080a and UVSL1080c are different palaeographically: the latter employs the so-called puḷi, a symbol used to mark a consonant without a vowel, and shows a more modern form of the consonant $\underline{r}$. In this respect, one should note that the two colophons were probably written by two different scribes, namely Ta. Kumāreț̣u and Mu. Kumārețtu. (3) The name Kumārețtu may correspond to the title held by various zamindars of Ețtaiyapuram (see Vadivelu 1903: 129-52, who writes 'Kumara Ettappa'). In particular, Mu. Kumārețtu may correspond to Jagavira Rama Kumara Ettappa Nayakar Aiyan, the 36th zamindar of Ețtaiyapuram (see Vadivelu 1903: 138-45, where various events that happened to the zamindar are reported from 1875 until his death in 1890): the syllable 'Mu' may, in fact, be understood as an abbreviation of the name of his father, namely Muthuswami Jagavira Rama Ettappa Nayakar Aiyan (see Vadivelu 1903: 138). However, the syllables 'Ta' of UVSL1080a would still remain problematic. (3) Nellaiyappar and Kāntimati are the names of the god and goddess venerated in the śaiva temple of Tirunelvēli called Nellaiyappar Tirukkōyil (Nellaiyappar Temple).

\section{OR2340j - Ṣoḍaśīkalyāṇīstotra (17 July 1891)}

[59r3] hariḥ | om | - śubham astu - devi | ślokaṃ 16 || śrīmahādev[3 syllables lost] [59r4] kollam 1066mtu āṭi \{M1\} 3 \{D2\} cantiracekapuram kirāmam ayyar śāstrikal kumāran †crī cuvāmi †kay yețuttu† - gaṇ[3 syllables lost] 
Harih om. May there be prosperity. The 16 verses for the Goddess. Śrī Mahādev... In the Kollam year 1066, month of Āṭi, 3rd day, śri (?) Cuvāmi son of Ayyar Sāastrikal from the village of Cantiracekapuram wrote [3 syllables lost].

Notes: (1) Possibly, ${ }^{\circ} \mathrm{mtu}$ should be amended to ${ }^{\circ} \mathrm{mta}$ (see section 4.1.1, fn. 16). (2) The expression tkay yețuttu could mean 'having held in the hand', thus possibly 'wrote' or 'copied'. However, in order for this reading to be possible, one should accept the presence of an odd graph used to write the syllable țu and that the word for 'hand' is spelled kay instead of kai.

\section{OR2344b - Devīmāhātmya (from 25 July to 5 August 1908)}

[46v2] śrīmahādevyai namah | śrīmatsarasvatyai namaḥ | śrīgurubhyo namah | śrīrā [mā] namah | [46v3] kollaṃ 1083 āṣā ḍhamāsam - 10 - ām tiyyati āraṃbhicca - 21 - ām tiyyati devī[46v4]mahātmyam mukiñcutu | śrīmahāde[46v5]vyai namah | śrī | śubham | [46v6 this line contains decorative signs only] [46v7] sundaran putran nārāyaṇan sva[46v8] hasthalikhitam | śrikkșṇāya namaḥ |

Honour to śrī Mahādevī. Honour to śrīmat Sarasvatī. Honour to the śrī gurus. Honour to śrī Rā[mā]. The Devīmāhātmya, which was begun in the Kollam [year] 1083, month of Āṣāḍha, 10th day, was completed on the 21st day. Honour to śrī Mahādevī. Śrī. Prosperity. Nārāyaṇan son of Sundaran wrote [it] with his own hand. Honour to śrī Kṛ̣̣ṇa.

\section{OR2345 - Jaiminīya Āraṇyaka Gāna (19 November 1863)}

[66v1] | hari om | [66v2] ity āraṇapāthasamāptah | śubham astu śrīgurubhyo namah | cuppaḷam kecavan āraṇakurantam 1039[66v3] āmta kārttika \{M4\}cam $5 t^{\circ}$ eluti mukuñcatu

Hari[h] om. The Āraṇapātha is completed. May there be prosperity, honour to the śrī gurus. Cuppalam (?) Kecavan finished writing the Āranakurantam in the Kollam year 1039, month of Kārttika, 5th day.

Notes: (1) The term cuppalam is rather unclear. It could be a variant spelling of either cuppalam or cuppalam, both meaning 'good merit'. (2) The word kecavan is also found scratched over the wooden cover as keśavan. (3) The way in which the vowel $u$ is attached to the consonant $\underline{l}$ in eluti is graphically unconventional.

\section{OR2347.1 - Devīmāhātmya (1 November 1789, 2 November 1849, or 4 November 1909)}

[77v1] śubham astu | śrīmahādevyai namah |--- [77v2] saumyanāmasa[ṃ] vatsaraṃ tulāmāa sam 19 \{D1\} udiccu 13 ñālikaiyāar tpottu devīmāhātmyam [77v3] samāptạ̣ --- śrīmahādevyai namaḥ| --- hariḥ om |--- 
May there be prosperity. Honour to śrī Mahādevī. In the [Jovian] year Saumya, month of Tulā, 19th day, once [the sun] has risen (udiccu), at the time of the 13th nālikai, the Devīmāhātmya was completed. Honour to śrī Mahādevī. Harih om.

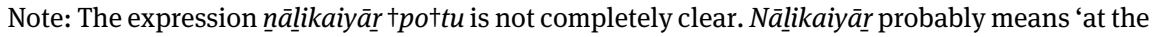
nālikai', with the term nālikai (a measure of time of 24 minutes; see section 4.1.7) marked with the locative ending - $\bar{a} \underline{n}$, which becomes $-\bar{a} \underline{r}$ because of sandhi. On the other hand, tpottu can either be read as potu (i.e. pōtu), meaning 'when' or 'at the time', or as setu (possibly a variant of seytu/ceytu, i.e. the absolutive form of the root cey- 'to make'), meaning 'having been made'. The former reading seems to be more consistent with the style of colophons, such as those of

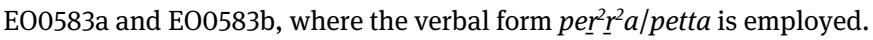

\section{OR2348 - Lalitātrišatīnāmāvalī (10 July 1800, 11 August 1860, or 13 August 1920)}

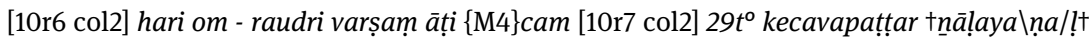
triśati [10r8 col2] arccañai mukiñcitu harihara[10r9 col2]viriñcebhyo namaḥ|

Hari[h] om. In the [Jovian] year Raudri, month of Āṭi, 29th day, Kecavapațtar Nālayaṇal (?) completed the Triśati Arccanai. Honour to Hari, Hara and Viriñca.

Notes: (1) The word ñālayanal (read nālayanal) is rather puzzling. It could either be part of the name of the scribe or part of the title of the work contained in the manuscript. In the former case, one might be at least tempted to amend it to Nārāyaṇal, since it is an attested personal name. In the latter case, it would be the Tamil counterpart of Lalitā (see title): could Nālayaṇal then be a (local) name for the goddess? (2) Note that the spelling of arccanai is in between the Sanskrit arccanā and the Tamil aruccañai. (3) Hari, Hara, and Viriñca are Viṣnu, Śiva, and Brahmā respectively.

\section{OR2355c,d,g,h}

\section{OR2355c - Pradoșārccana (12 November 1902)}

[36r2] pradoșārccanasamāptam | [36r3] 1078 - mta tulāmāsam 27ā \{D3\} samāptam----

The Pradoșārccana is completed. It is completed in the Kollam year 1078, month of Tulā, 27th [day (?)].

Note: Regarding the symbol written after $27 \bar{a}$, see section 4.1.4. 


\section{OR2355d - Rṣipañcamivratodyāpana (12 November 1902)}

[49v3] hari om śubham astu | rșipañcamivratodyāpanasamāptam | 78 tulāṃ 27ā tiyati [49v4] ve kṛ̣ṇavāddhyārkka veṇtị rāmapațțar svahastalikhitam |---

Harih om. May there be prosperity. The Rșipañcamivratodyāpana is completed. [Kollam year 10]78, month of Tulā, 27th day. As desired by Kṛṣnavāddhyār, [son of] Ve[kițiśvaravāddhyār], Rāmapaț̣ar wrote [it] with his own hand.

Notes: (1) Read krṣnavaddhyārkku for kṛṣnavaddhyārkka. (2) Most probably, the syllable ve stands for Ve[kiṭiśvaravāddhyār], i.e. the name of Kṛṣnavāddhyār's father as indicated in OR2355g.

\section{OR2355g - Somavārārccana (15 November 1902)}

[65v1 col2] somavārārccanasamāptam śubham | [65v2 col2] kollam 1078 - āmta tulāmāsam 30 tiyati - [65v3 col2] vekițišvaravāddhyār puttiran kṛ $65 \mathrm{v} 4$ col2]ș̣avāddhyār grandham nārāyaṇa[65v5]pațtar puttiran rāmayan svahastalikhitam ---

The Somavārārccana is completed. Prosperity. In the Kollam year 1087, month of Tulā, 30th day, the book of Kṛ̣nạavāddhyār, son of Vekiṭiśvaravāddhyār, was copied by Rāmayan, son of Nārāyaṇapaț̣ar, with his own hand.

\section{OR2355h - Nakṣatradevatā Ṛk (no date)}

[73v6] hariḥ - om kṛṣnavāttiyār grandhaṃ | rāman svahastalikhitaṃ |

Harih om. The book of Kṛ̣navāāttiyār. Rāman copied [it] with his own hand.

\section{OR2359 - Cakravidhi (28 September 1803, 28 September 1863, or 30 Septem- ber 1923)}

[9r2] śrīcakravi[9r3]dhih | saṃpūrṇam --- rudhirotgāri \{YJ5\} potțāci \{M1\} 14 \{D1\} ayyyā [9r4]svāmidīkșitan uțaya grandham hariḥ om |---

The Śrīcakravidhi is completed. Jovian year Rudhirotgāri, month of Poțtāci, 14th day. The book belongs to A[r]yyāsvāmidīkṣitan. Harih om.

Note: Potțāci is a contraction of puratțāci. 


\section{MS2.40 - Śivadharma (22 April 1830)}

[167r6] vikratināmasaṃvatsaram ci[X]ttirai $\{\mathrm{M} 2\} 12$ \{D1\} guruvāramu aśsanīnakșatra[X]mu kūțtuna cubhadinattil eluti muhiñcutu | śiva śiva ---

On the auspicious day on which the [Jovian] year called Vikrti, month of Cittirai, 12th day, Thursday falls together with the constellation of Aśvanī, [this manuscript] was fully written. Śiva, Śiva.

Notes: (1) Vikratio should be read as vikrta ${ }^{\circ}$, of which it might be thought to be a variant. (2) The syllable $m u^{\circ}$ should be read as mum.

\section{References}

Arden, Albert Henry (1962 [1942]). A Progressive Grammar of Common Tamil. Madras: The Christian Literature Society.

Burnell, A.C. (1880). A Tentative List of Books and Some Mss. Relating to the History of the Portuguese in India Proper. Mangalore: Basel Mission Press.

Franceschini, Marco (forthcoming). A Study on Grantha Script. Pondichéry: IFP-EFEO.

Grimal, François / Ganesan, T. (eds.) (2002). Descriptive Catalogue of Manuscripts in the French Institute of Pondicherry, vol. IV. mss. 376-475. Pondichéry: IFP-EFEO.

Grünendahl, Reinhold (2001). South Indian Scripts in Sanskrit Manuscripts and Prints. Wiesbaden: Harrassowitz Verlag.

Katre, Sumitra M. (1987). Așțādhyāyī of Pāṇini. Austin: University of Texas Press.

Pillai, L.D. Swamikannu (1911). Indian Chronology (Solar, Lunar and Planetary). A Practical Guide to the Interpretation and Verification of Tithis, Nakshatras, Horoscopes and Other Indian Time-records. B.C. 1 to A.D. 2000. Madras: Grant \& Co.

Pillai, L.D. Swamikannu (1922). An Indian Ephemeris, A.D. 700 to A.D. 1799. Vol. I.I: General principles and tables; Vol. VI: A.D. 1600 to A.D. 1799. Madras: Government Press.

Pillai, L.D. Swamikannu (1923). An Indian Ephemeris, A.D. 1800 to A.D. 2000. Madras: Government Press.

Pope, George Uglow (1859). A Tamil Handbook: or full introduction to the common dialect of that language, on the plan of Ollendorf and Arnold, for the use of foreigners learning Tamil, and of Tamilians learning English, 2nd edition (1st ed. 1855). Madras: J. Higginbotham.

Ramanuja Aiyangar, T. et al. (ed.) (1956). A Descriptive Catalogue of Tamil Manuscripts in Makāmakōpātyāya Dr. V. Swāmināthaiyar Library (Makāmakōpātyāya Ṭākțar U.Vē. Cāminātaiyar Nūlnilaiyac Cuvațikaḷin Viḷakkam), vol. I. Madras: Mahamahopadhyaya Dr. V. Swaminathaiyar Library.

Renou, Louis / Filliozat, Jean (1953). L'Inde classique. Manuel des études indiennes. Paris: Imprimerie Nationale / Hanoi: EFEO.

Sarma, K.V. (1996). “Kollam Era," in: Indian Journal of History of Science 31(1): 93-99.

Sewell, Robert (1896). The Indian Calendar. With tables for conversion of Hindu and Muhammadan into A.D. dates, and vice versa. London: Swan Sonneschein \& Co. 
Vadivelu, A. (1903). The Aristocracy of Southern India. Madras: Vest \& Co.

Varadachari, V. (ed.) (1986). Catalogue descriptif des manuscrits, vol. I. mss. 1-115. Pondichéry: IFP-EFEO.

Varadachari, V. (ed.) (1987). Catalogue descriptif des manuscrits, vol II. mss. 116-275. Pondichéry: IFP-EFEO.

Varadachari, V. (ed.) (1990). Catalogue descriptif des manuscrits, vol. III. mss. 276-375. Pondichéry: IFP-EFEO.

Venkatachari, K.K.A. (1978). The Maṇipravāla Literature of the Śrīvaișnava Ācāryas: 12 th to 15th Century A.D. Bombay: Ananthacharya Research Institute.

Wagner, Esther-Miriam / Outhwaite, Ben / Beinhoff, Bettina (eds.) (2013). Scribes as Agents of Language Change. Boston / Berlin: De Gruyter Mouton.

Wilden, Eva (2014). Manuscript, Print and Memory: Relics of the Cańkam in Tamil Nadu. Berlin / Munich / Boston: De Gruyter Mouton.

Winslow, Miron (1862). A Comprehensive Tamil and English Dictionary of High and Low Tamil. Madras: P.R. Hunt.

Zvelebil, Kamil (1959). “Dialects in Tamil, I-II,” in: Archiv Orientální 27, 272-317, 572-603.

Zvelebil, Kamil (1960). “Dialects in Tamil, III: Madurai,” in: Archiv Orientální 28, 414-56.

Zvelebil, Kamil (1963). "Dialects in Tamil, IV: Erode, Tuticorin, Ramnad," in: Archiv Orientální 31, 635-68.

\section{Dictionaries}

Glossary of Historical Tamil Vaishnava Prose (Vainava Urainațai Varalārru Murait Tamiḷp Pērakarāti) (2001). 3 vols. Cennai: Cānti Cātañā.

Tamil Lexicon (1924-39). 7 vols. Madras: Diocesan Press.

Monier-Williams, Monier (1899). A Sanskrit-English Dictionary. Oxford: Clarendon Press.

\section{Webography}

(Links were last checked on 23 September 2015)

On the suffix -āmta:

/1/ 〈http://negombotamilweb.blogspot.de/2012/05/blog-post_10.html>

/2/ <http://www.tamilmirror.lk/2010-07-14-09-13-23/2010-08-12-10-11-54/2010-08-12-10-1424/82057.html>

/3/ <http://www.globaltamilnews.net/GTMNEditorial/tabid/71/articleType/ArticleView/articleld/24990/language/ta-IN/--27--.aspx>

Unicode:

/4/〈http://www.unicode.org/charts/PDF/U0B80.pdf〉 
Isalimadai:

/5/ <usof.gov.in/usof-cms/state/tamilnadu.xls>

/6/ 〈http://ccatn.gov.in/usofiles/infra/cluster69.pdf〉

<http://ccatn.gov.in/usofiles/infra/cluster69.pdf>

Tirumēñinātar temple:

/7/ 〈http://temple.dinamalar.com/New.php?id=606〉

Tirucculi:

/8/ 〈http://en.wikipedia.org/wiki/Virudhunagar_district〉

Veḷańkoḷi:

/9/ <https://www.google.it/maps/place/Vellamkolli/@8.7146011,76.7597171,10z/

data $=$ !4m2!3m1!1s0x3b05c26650caaaa1:0xbc099ac68bd30861> 

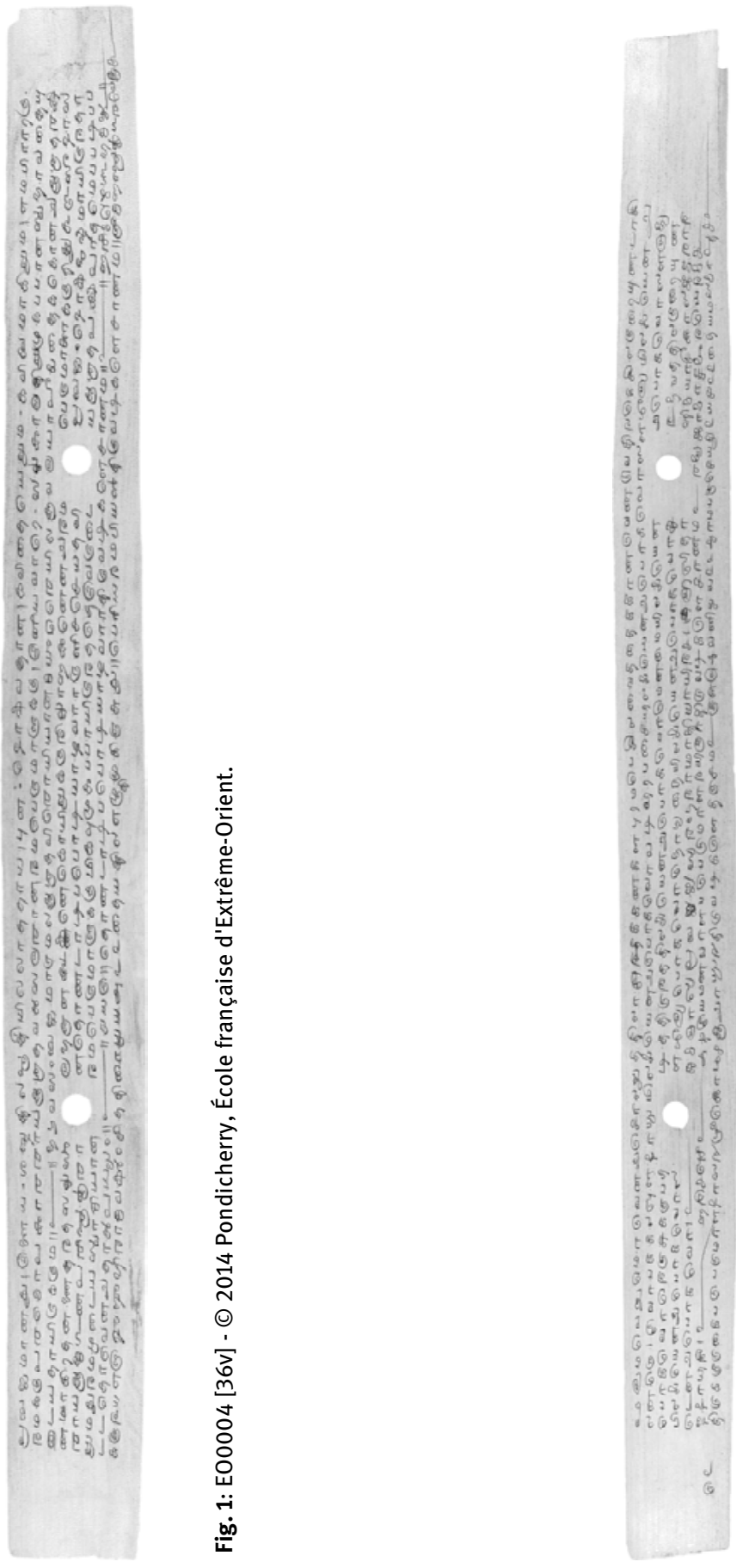

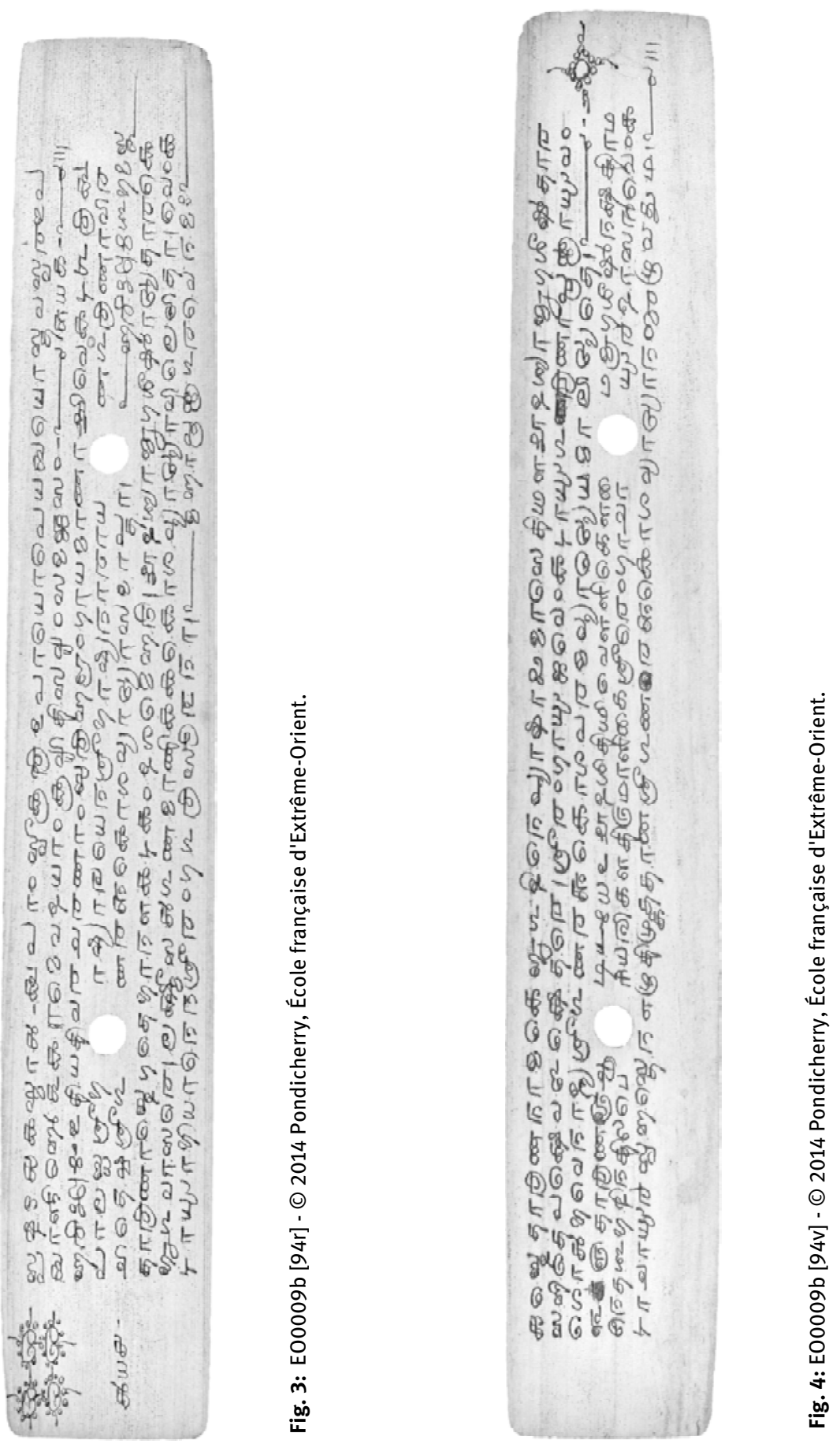

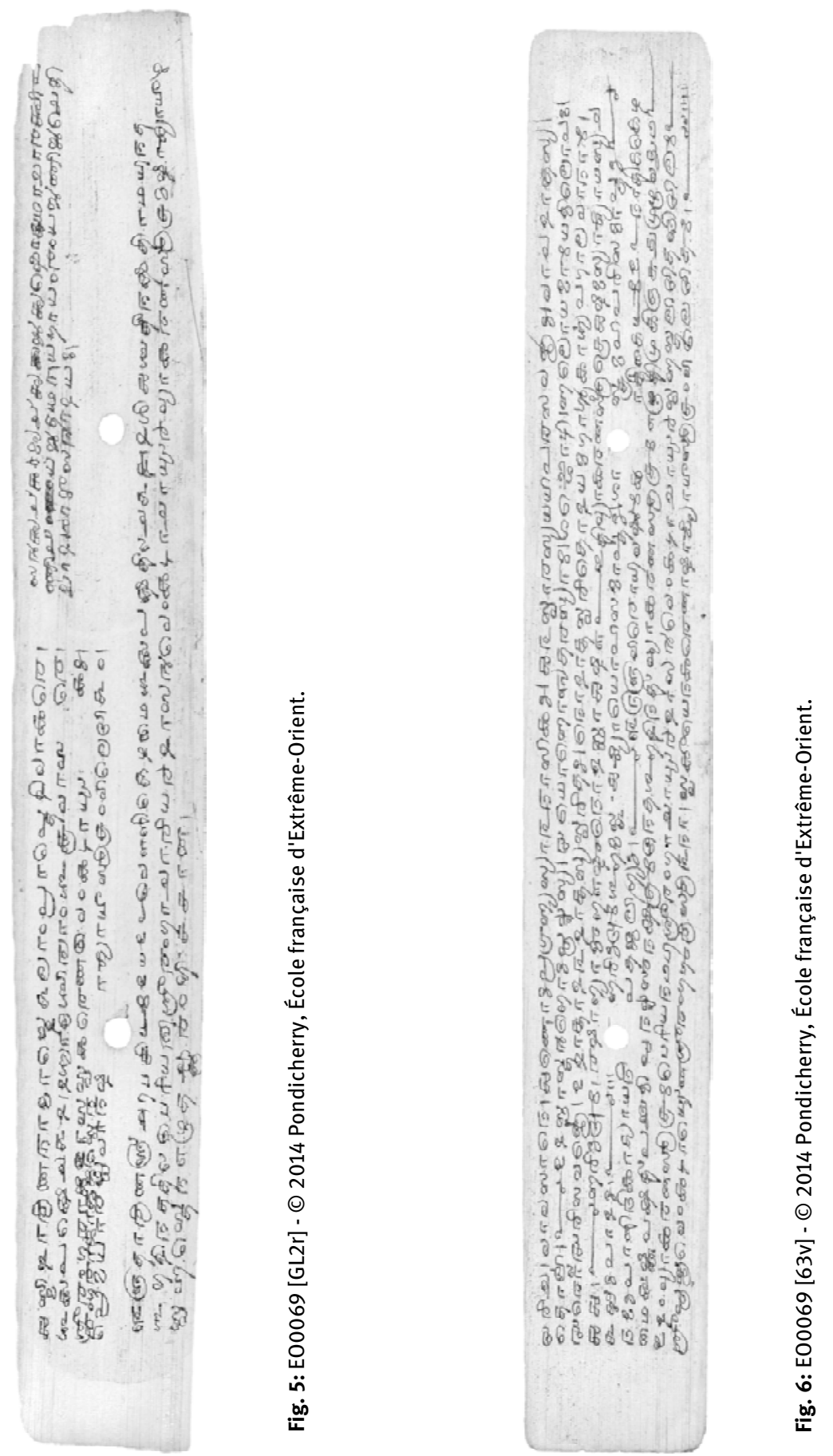

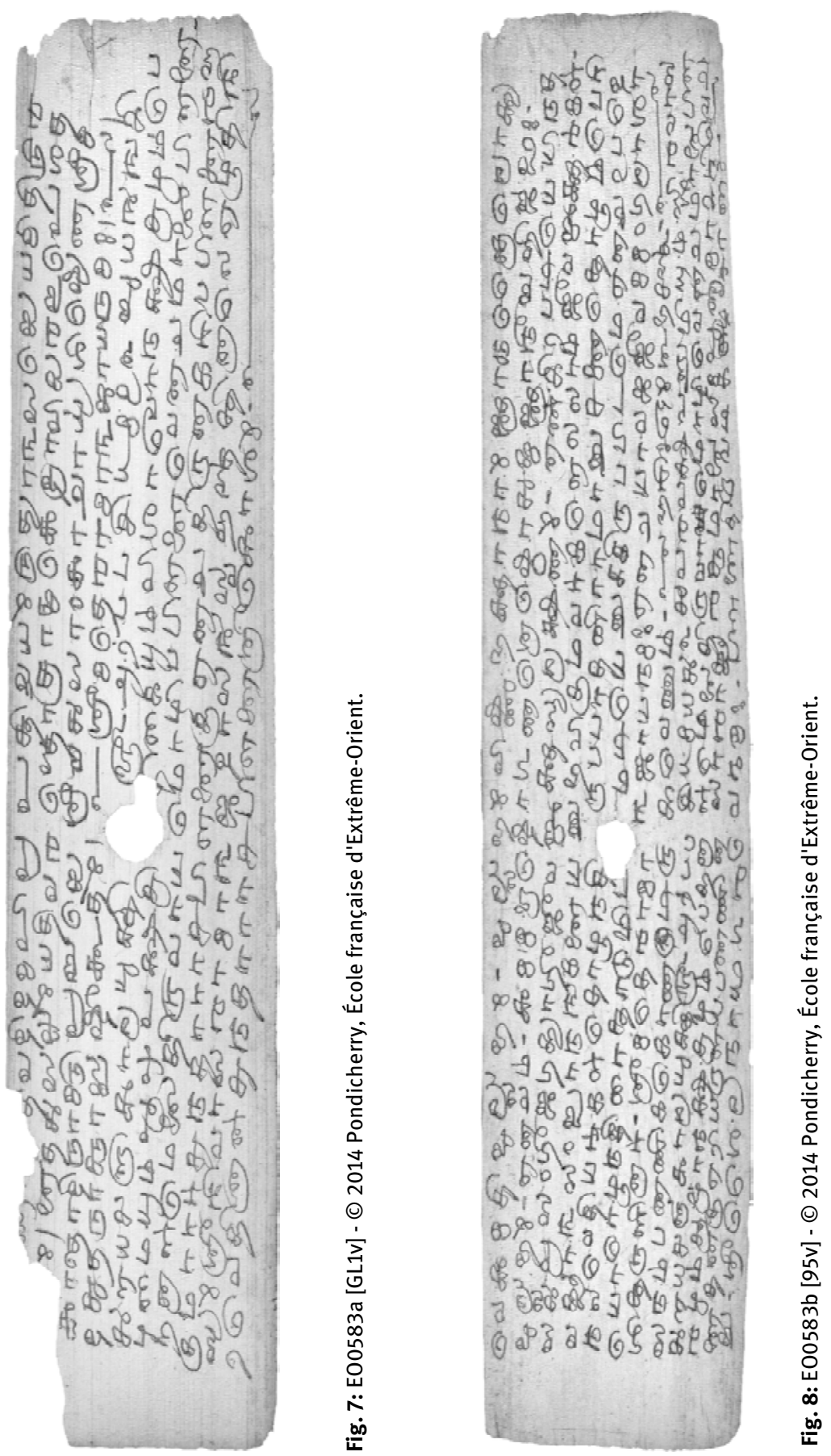
